\title{
NIOSH-DOD-OSHA SPONSORED Chemical and Biological Respiratory Protection Workshop Report
}

\author{
John M. Dower, Richard W. Metzler, Frank M. Palya, \\ Jeff A. Peterson, Molly Pickett-Harner
}

\author{
U.S. DEPARTMENT OF HEALTH AND HUMAN SERVICES \\ Public Health Service \\ Centers for Disease Control and Prevention \\ National Institute for Occupational Safety and Health
}

February 2000 


\section{FOREWORD}

In May 1998, President Clinton issued Presidential Decision Directive 62 (PDD-62), "Combating Terrorism" and made the fight against terrorism a national domestic security issue. This Directive creates a new and more systematic approach to achieve the President's goal of ensuring that we meet the threat of terrorism in the 21 st century with the same rigor that we have met military threats in this century. PDD-62 establishes the Office of the National Coordinator for Security, Infrastructure Protection, and Counter-Terrorism. The National Coordinator will oversee the broad variety of relevant policies and programs including such areas as counter-terrorism, protection of critical infrastructure, preparedness, and consequence management for weapons of mass destruction. NIOSH, DOD, and OSHA organized this workshop to bring together partners to coordinate activities in support of this Directive.

Over the fifteen months since publication of PDD-62, municipal, state, and national guard responder groups, particularly those in locations considered potential targets, have been hastily developing response and consequence management plans. These plans-which include establishing procedural and equipment infrastructures and training emergency response personnel for chemical and biological terrorism-have raised numerous issues about potential attack scenarios and agents, such as how best to address hazard detection, personal protective equipment, responder needs, and public health and medical concerns.

This Workshop provided a forum for over 140 subject-matter experts representing 63 different emergency responder, fire fighter, domestic preparedness, equipment manufacturing, federal research, and state and federal regulatory organizations. Participants openly discussed chemical and biological terrorism issues, exchanged information, and developed new partnerships. If attendance and participation are any indication of success, the Workshop was indeed successful. I wish to thank the cosponsors of this Workshop and the employees, employers and organizations that participated. I also wish to thank the attendees for their interest, their avid participation in discussions, and their tenacity to travel through a major winter storm to attend, because it was in the open dialogues that the key issues became obvious and opportunities for solutions surfaced. I look forward to continuing collaborations as we collectively pursue national domestic preparedness.

Linda Rosenstock, M.D., M.P.H. Director 


\title{
ORDERING INFORMATION
}

Copies of National Institute for Occupational Safety and Health (NIOSH) documents and information about occupational safety and health are available from

\author{
NIOSH-Publications Dissemination \\ 4676 Columbia Parkway \\ Cincinnati, OH 45226-1998
}

\begin{tabular}{|c|c|}
\hline Fax: & $513-533-8573$ \\
\hline Telephone: & $\begin{array}{l}1-800-35-\mathrm{NIOSH} \\
(1-800-356-4674)\end{array}$ \\
\hline $\begin{array}{l}\text { E-mail: } \\
\text { Web site: }\end{array}$ & $\begin{array}{l}\text { pubstaft@cdc.gov } \\
\text { www.cdc.gov/niosh }\end{array}$ \\
\hline
\end{tabular}

This document is in the public domain and may be freely copied or reprinted.

Disclaimer: Mention of any company or product does not constitute endorsement by NIOSH.

DHHS (NIOSH) Publication No. 2000-122

February 2000 


\section{Table of Contents}

Executive Summary $\ldots \ldots \ldots \ldots \ldots \ldots \ldots \ldots \ldots \ldots \ldots \ldots \ldots \ldots \ldots$

Purpose and Opening Remarks .................. iii

Workshop Sessions . . . . . . . . . . . . . . . . . . . . 1-24

Session \# 1

Chemical and/or Biological Incidents: Associated Hazards . . . . . . . . . . . 1-6

Plenary Presentations . . . . . . . . . . . . . . . . 1-2

Session \#2

Workgroup Discussions . . . . . . . . . . . . . . . 2-6

Responders and Their Respiratory Protection Needs . . . . . . . . . . . . . 7-11

Plenary Presentations ..................... $7-8$

Session \#3

Workgroup Discussions . . . . . . . . . . . . . . 8-11

Respirator Standards for Chemical and/or Biological Incident Responses 12-19

Plenary Presentations . . . . . . . . . . . . . . . . . . . . . 12-13

Session \#4

Workgroup Discussions . . . . . . . . . . . . . . . . . . 13-19

Chemical and/or Biological Response Plans:

Public Health and Medical Community Concerns . . . . . . . . . . . . . . 20-24

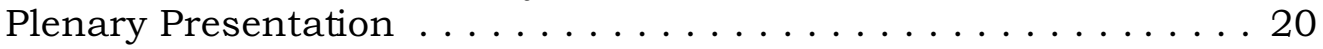

Workgroup Discussions . . . . . . . . . . . . . . . . . 21-24

Conclusions and Suggested Activities . . . . . . . . . . . 25-26

\section{Appendices}

A. Plenary Speaker Abstracts and Biographies . . . . . . . . . . . . . 27-42

B. Registrants and Attendees . . . . . . . . . . . . . . . . 43-60

C. Glossary of Abbreviations and Acronyms . . . . . . . . . . . . . . 61-64

D. Chemical and Biological Agents of Concern . . . . . . . . . . . . 65-72

E. Interagency Equipment Standardization Board Members . . . . . . . . 73-76 


\section{EXECUTIVE SUMMARY}

Since publication of Presidential Initiative 62, municipal, state, and national guard responder groups have been developing response plans and establishing the procedural and equipment infrastructures to capably respond to chemical and/or biological terrorism and other crisis situations.

The National Institute for Occupational Safety and Health (NIOSH) co-sponsored this technical Workshop together with the Department of Defense (DOD) - US Army Soldier and Biological Chemical Command (SBCCOM) and the Occupational Safety and Health Administration (OSHA). Workshop objectives were to: 1) identify and understand the hazards associated with chemical and/or biological incidents, 2) identify the different responders and their respiratory protection needs, 3) determine which respirators and selection criteria are currently being utilized for response to these types of incidents, and 4) determine public health and medical community concerns which must be considered in developing a standard for chemical and/or biological respiratory protective devices.

This Workshop provided a forum for over 140 representatives from 63 different emergency responder, fire fighter, domestic preparedness, equipment manufacturing, federal research, and state and federal regulatory organizations. Participants openly discussed issues, exchanged information, and learned about current re spiratory protection issues associated with incidents involving chemical and biological agents. The attendees were subject-matter experts, stakeholders, and partners with a common interest of assuring proper respiratory protection for emergency responders and other worker groups faced with the responsibility of responding to incidents involving chemical and/or biological threats.

Presentations were given by representatives of government agencies, private laboratories, scientific experts, and rescue organizations. Participants explored the expertise and responsibilities of the Federal Bureau of Investigation (FBI), National Domestic Preparedness Office (NDPO), the Interagency Board for Standardization and Interoperability, NIOSH, DOD, SBCCOM, New York City Office of Emergency Management, and others.

Attendees gained a better understanding of the kinds of chemical and/or biological threats that are possible. Sources for obtaining further information were identified. The need for additional research, guidelines, and standards were identified in the following areas:

- $\quad$ exposure limits and technology for assessing chemical and/or biological concentrations of response scenarios;

- improved chemical and/or biological detection and monitoring capabilities;

- reliable information with which to define acute vs. chronic doses and their immediate and long-term health effects;

- applicability of military data. 
Workshop participants believed that everyone associated with res ponse to a chemical and/or biological incident needs to be adequately protected and that the level of protection required will vary. The diverse group of emergency responders potentially include: local public safety workers (fire fighters, police, HazMat, bomb squad, Emergency Medical Service [EMS]); local government specialty response (Department of Environmental Protection [DEP], Department of Highways [DOH], county emergency planning personnel, public health officials); local utility workers (electric, gas, water); state government specialty response (national guard, state emergency planning personnel, Department of Environmental Resources [DER], public health officials); federal law enforcement personnel (FBI, Alcohol, Tobacco and Firearms [ATF]); Public Health Service (PHS) (Disaster Medical Assistance Team [DMAT], National Medical Response Team [NMRT], Disaster Mortuary Team [DMORT]); private clinics and hospital workers.

The conference identified immediate responder needs in the following areas:

- $\quad$ NIOSH certification of air-pu rifying respirators (APR), powered airpurifying respirators (PAPR), self-contained breathing apparatus (SCBA), and personal protective equipment (PPE) for use against these threats;

- training assistance with PPE and respirator selection in domestic preparedness-planning;

- $\quad$ alternatives to SCBA for certain threat scenarios;

- $\quad$ assurance that SCBA will survive an exposure to chemical warfare agents and critical components will not be degraded;

- implementation of DOD respirator standards, tests, and qualification requirements where applicable;

- identification of appropriate cartridge/cannister performance tests; and - relevant protection factor $(\mathrm{PF})$ protocols and valid assigned protection factor (APF) assessment methods.

The Workshop was closed with assurance that NIOSH, DOD, and OSHA will continue working with partners to investigate the funding and collaborations needed to develop certification standards for chemical and/or biological respiratory equipment and the other issues raised. Certainly, what can be achieved will be tempered or accelerated by the funding and resources that are or will become available. This report will be available upon request and may be used by attendees to form future partnerships and collaborations to address this emerging national issue. 


\section{PURPOSE \& OPENING REMARKS}

Dr. Gregory W. Wagner, Director of the Division of Respiratory Disease Studies (DRDS) NIOSH welcomed participants to the Workshop and thanked them on behalf of the DOD-SBCCOM, OSHA, and NIOSH. He stated that the purpose of the meeting was to take a first step in exploring respiratory protection issues by bringing together subject-matter experts who have the common interest of ensuring that the workers who risk their own lives to save others are themselves properly protected against the most deadly respiratory hazards. Dr. Wagner stated that the experts in the room have the combined knowledge and resources to identify and understand chemical and biological hazards, establish user needs, define the respiratory protection needed to properly protect responders, and explore the issues associated with the public health and the medical community's need for respirator protection.

Richard W. Metzler, Chief of the Respirator Branch, DRDS, NIOSH, described the program and agenda and reviewed the purpose of the Workshop:

- To bring all interested parties together in a forum that would provide an opportunity to exchange information.

- To better understand "who is doing what."

- To identify and understand the hazards associated with responding to chemical and/or biological incidents.

- $\quad$ To identify requisite responders and their needs for respiratory protection and other protective equipment.

- To identify and understand the performance, reliability, and quality characteristics of respiratory protection that may be needed by individuals responding to chemical and/or biological terrorist incidents, particularly the respirator selection criteria currently utilized for such incidents.

- To determine public health and medical community concerns which must be considered in the development of a voluntary standard for chemical and/or biological respiratory protective devices.

The Workshop agenda addressed four major topics: health hazards, user needs, respirator certification standards and the broader issues of public health. Each of these topics were introduced at a plenary session by one or two keynote speakers who are recognized experts on the topic. Each plenary session was followed by a workgroup exercise in which participants from diverse backgrounds addressed questions that were intended to define and answer issues related to that plenary session's topic. Then, to facilitate the multiple viewpoints, the workshop was divided into four workgroups. After the workgroups addressed the prepared questions on a particular topic, a follow-up plenary session was held to receive, from all groups, presentations on their defined issues and answers to the topic questions.

-iii- 


\section{WORKSHOP SESSIONS}

\section{Session \#1 \\ Chemical and/or Biological Incidents: Associated Hazards}

The purpose of Session \# 1 was to identify and understand the hazards associated with a response effort to a chemical and/or biological incident.

\section{Plenary Presentations Chemical and/or Biological Incidents: Associated Hazards}

First Presentation: James Genovese, US Army, SBCCOM

Mr. Genovese provided the military's perspective on the most probable threats responders may face and the approach that should be utilized for effective response. Mr. Genovese emphasized that the response to chemical and/or biological incidents will require a proactive integration of both sectors of our government-military and civilian-in order to optimize effectiveness and minimize casualties to emergency responders at any level of city, regional, state, or federal government. He emphasized that a variety of readily available toxic materials could be utilized by a terrorist, including chemical and/or biological agents. Toxic industrial chemicals, as well as military-unique chemical and/or biological hazards, may pose novel challenges to our current protection systems. [See Appendix D: Chemical and Biological Agents of Concern.] Because incident responders could be confronted with such a broad spectrum of hazards (from mildly toxic to lethal) and incident locales (from interior to exterior), it is paramount that we approach these response issues from a personal protective equipment systems perspective.

\section{Second Presentation: Andy Bringuel, FBI, NDPO}

Supervisory Special Agent Bringuel addressed the NDPO programs being developed and NDPO's assessment of the most probable domestic threats. Mr. Bringuel described the mission of the NDPO as developing an interagency effort to enhance coordination among federal programs offering terrorism preparedness assistance to state and local communities. Federal agency participation at the NDPO currently includes the DOD, the Department of Energy (DOE), the Department of Health and Human Services (DHHS), the Environmental Protection Agency (EPA), the Federal Emergency Management Age ncy (FEMA), the FBI, the National Guard Bureau, the Office of Justice Programs (OJP), and others. State and local experts are also represented at the NDPO and provide input for the formulation of programs. The NDPO will become the clearinghouse for all weapons of mass destruction (WMD) related issues and is organized into the following programs: planning, 
exercises, equipment, information dissemination, and health issues. Thus the NDPO will serve as a single program and policy coordination office for domestic preparedness programs for state and local communities. The NDPO is not intended to be the creation of a new federal bureaucracy nor will it subsume the assistance programs under the management of other agencies.

\section{Workgroup Discussions Chemical and/or Biological Incidents: Associated Hazards}

\section{What hazards (risks and exposures) are not well defined or understood?}

Terrorist acts demand public attention and education. Terrorism is being conducted by highly-motivated, well-educated individuals and groups who are able to obtain the equipment and materials to effectively create mass destruction through the use of chemical and/or biological weapons. Much remains to be understood about the hazards associated with the response, management, and mitigation of a terrorist incident.

Several attendees pointed out that chemical and biological incidents may differ significantly and require separate and distinct procedures for response, management, and mitigation. For example, a chemical incident may produce many casualties with acute symptoms within minutes after exposure to a lethal concentration. Exposure to a biological incident will produce many casualties; however, symptoms may not manifest for a period of time, anywhere from 24 hours to three weeks later, depending on the agent used.

A concern was expressed that the risks and hazards associated with a response to a terrorist incident are not well-defined. Due to the lack of experience in dealing with these types of threats, and the uncertainties associated with the hazards and risks, both responders and the general public would experience increased levels of panic. It was suggested that training, utilizing the most current knowledge gleaned from mock disasters, is critical to responder readiness. Another suggestion was that military models for predicting hazards that exist for battlefield scenarios could be adapted to help model and predict the risks and hazards associated with domestic terrorism-assuming the scenarios and the acceptable risk could be defined. A rebuttal discussion questioned the validity of such models and the level of risk that is acceptable for civilian responders who risk their own lives to save others.

The majority of the workgroup attendees agreed that chemical and/or biological threats are not well understood by civilian responders. For example, the chronic effects of repeated short-term exposures to many chemical agents are as yet unknown. Moreover, it is unknown how communities would need to manage situations involving biological agents because an incident might not be discovered 
until patients, who could have dispersed throughout the area, start showing up at doctor's offices and hospital emergency rooms.

The group generally agreed that exotic agents, such as chemical warfare agents, would probably not be utilized because these agents are controlled and difficult to obtain and transport. The chemicals most likely to be utilized are hazardous industrial chemicals and these were discussed at length. The DOD has developed a list of hazardous industrial che micals that are of interest from a military perspective. Many attendees felt that agents that could be utilized in a domestic terrorist act need to be prioritized, based on scenarios that are probable for use in domestic settings.

The majority in the four workgroups agreed that emergency response to incidents involving chemical warfare agents should be handled as standard hazardous materials incidents; however, some special training techniques and detection equipment will be required. One concern is that many responders entering contaminated areas in level A equipment (fully-encapsulated suits and SCBA) will need to be in level A protection for prolonged periods of time (8-12 hours). There are physiological stresses and hazards associated with long-term PPE utilization. Another concern is that response to a chemical warfare agent attack is significantly different than response to a traditional hazardous materials incident for which standardized procedures have been established. When responding to a traditional hazardous materials (HazMat) incident, information to identify the contaminant is usually quickly available (Bill of Lading, Placards, etc.) and enough information is available from sources that can be easily contacted to identify the associated hazards. This "advance" information will probably not be available at terrorist incidents.

\section{Where do stakeholders get information on the hazards?}

Most information about the hazards associated with response, management, and mitigation of a chemical or biological incident is gained through domestic preparedness training and other resources available to the response community. Government agencies identified as being able to offer technical expertise on these topics are the: Agency for Toxic Substances and Disease Registry (ATSDR), Centers for Disease Control and Prevention (CDC), DOD, DOE, Department of Justice (DOJ), EPA, FBI, NDPO, FEMA, NIOSH, the National Institute of Standards and Technology (NIST), Nuclear Regulatory Commission (NRC), and OSHA.

There are several sources in the DOD that have interests and expertise on biological and/or chemical terrorism. Currently, the United States Army utilizes the SBCCOM at the Aberdeen Proving Ground, Edgewood to administer the Domestic Preparedness Training Program. This program has a mission of training the first responders of the 120 largest US cities about the hazards, response procedures, and equipment required to respond to a chemical and/or biological agent incident. Through the Domestic Preparedness Program, SBCCOM disseminates information and test data so that individuals responsible for selecting 
equipment can make appropriate choices. SBCCOM also maintains a hotline-which provides real-time referrals-that municipal responders may utilize in the event of an incident.* For information on biologicals and infectious diseases, the US Army Medical Research Institute of Infectious Diseases (USAMRIID) located at Fort Detrick, Frederick, MD and the CDC and/or Agency for Toxic Substances and Disease Registry (ATSDR), Atlanta, GA are reliable sources.

Many attendees said they rely on trade and labor unions to provide information that is needed to prepare for and respond to chemical and/or biological incidents. Some of the organizations that are looked to for guidance and knowledge in this arena are the: International Association of Fire Chiefs (IAFC), International Association of Firefighters (IAFF), International Association of Police Chiefs (IAPC), and International Chemical Workers Union (ICWU). 'Standard tools of the trade,' such as Chemical Transportation Emergency Center (ChemTrec), the Department of Transportation (DOT) Handbook, Material Safety Data Sheets (MSDS's), and the NIOSH Pocket Guide to Chemical Hazards are also utilized when responding to hazardous materials incidents, but do not necessarily contain specific information on biological and/or chemical warfare threats.

* Domestic Preparedness Help Line: 800-368-6498 or E-mail cbhelp@cbdcom.apgea.army.mil

¥ Toll free service 800-262-8200

\section{Where are the gaps in knowledge and resources?}

There is no central source which provides technical and operational information about chemical and/or biological warfare agents or industrial agents. The majority of the attendees suggested that, as a priority, NDPO should establish a database of information on industrial and military agents. This database should contain literature which has been technically critiqued, unclassified, and readily available to responders. It was suggested that in the event that all information could not be unclassified, each city or municipality should have at least one individual who has the proper security clearances to access and obtain classified information from the military or federal law enforcement and intelligence agencies. [Note: NDPO may have provided a solution to this: WMD coordinators have now been appointed and stationed at regional FBI offices.]

The majority of attendees agreed that sufficient information is not readily available with respect to reference materials. ChemTrec, the DOT Handbook, MSDS, and the NIOSH Pocket Guide to Chemical Hazards, do not contain adequate information on chemical and/or biological warfare agents. Attendees also said that a list of acceptable respirators and chemical protective clothing-qualified for responders to utilize in these scenarios-is needed. The NIOSH Pocket Guide should be updated to include chemical and/or biological threat agents, be available as a CD ROM or Internet site, and contain PPE recommendations based on specific hazardous agent(s). This Guide should be available for every incident site.

Attendees expressed concerns that accurate, real-time, rapid response detection equipment does not exist, even though detection is key to selecting adequate 
personal protective equipment (PPE). Some attendees felt that adequate PPE decisions could not be made even if detection equipment did exist because there are still too many unknowns present, e.g., exposure limits do not exist, chronic effects of exposure have not been evaluated, etc. Furthermore, mixtures of agents may be present which detectors will not adequately detect-a serious concern because exposure limits and doses, as well as the acute and chronic effects of mixtures, are not known. Several participants suggested that using traditional industrial hygiene models, which compare environmental concentrations to recommended exposure limits, is adequate for selecting PPE.

\section{Who are the authorities needed to define exposures and risks? What programs must be coordinated to bring the authorities together?}

Responders stated that they are obligated to follow OSHA regulations and NIOSH guidelines. Some stated that the solution is for NIOSH and OSHA to develop and coordinate a team of experts to address the protection issues associated with terrorism. It was suggested that NIOSH should: be the agency which provides an oversight role with regard to developing standards for personal protective equipment for chemical and/or biological applications; play a facilitation role with federal regulators and consensus standards organizations to ensure national acceptance of the standards and equipment that becomes available; and evaluate and offer input into the Domestic Preparedness Training Program currently administered by SBCCOM. Attendees emphasized that the user community must be involved in any efforts made to advance technology in this arena.

Some attendees felt that consensus standards organizations, such as the American National Standards Institute (ANSI) or the National Fire Protection Association (NFPA), may be the best mechanism for creating standards. Recommendations could then be adopted by the federal agency responsible for coordinating efforts related to chemical and/or biological hazards and threats. However, these types of standards are generated by achieving consensus from committee members and when agreement cannot be achieved, changes are made, based on majority opinions, that do not always result in the most protective standards. Other attendees argued that consensus standard organizations have a long lead time that is no faster than the federal regulatory promulgation process; thus they would rather have federal regulations controlling the effectiveness, quality, and reliability of the equipment being developed rather than consensus standard organizations.

The following is a list of authorities who need to be involved in defining policies and standards: the American College of Emergency Physicians (ACEP), the CDC, the DOD's SBCCOM and USAMRIID, the DOE, the DOJ, the FBI, equipment manufacturers, FEMA, IAFF, IAFC, NDPO, NFPA, NIOSH, NIST, OSHA, Rocky Mountain Center for Law Enforcement, and state emergency management agencies. 
Attendees agreed that the NDPO's role will provide a great service if input from the end users is obtained and used in this early stage of planning domestic preparedness.

\section{Other perceived issues and special concerns?}

Attendees expressed a concern that information being provided through the Domestic Preparedness Program and other agencies is not complete due to the military's security classification. In some instances the information obtained is conflicting. Thus, responders lack confidence in the information they are obtaining. To minimize the number of casualties through direct exposure, contamination transfer, or panic, an Incident Commander needs complete and accurate information.

Standards for additional PPE protection levels are needed beyond those currently available for just level A protection. A systems approach is preferable and should consist of a matrix which defines the level of protective equipment (suit, respirators, gloves) needed in each responder location at an incident scene. Criteria to identify hazard levels need to be determined in terms of exposure limits based on an assessment of the toxin and its concentration and method of dispersion. Without the ability to determine the mode of dispersion, first responders and public officials will be unable to estimate the extent of exposure; thus, appropriate response to affected populations will be delayed.

Concerns were also raised about potential hazards associated with the use of PPE by inexperienced responders, such as law enforcement and emergency medical personnel. Such equipment could offer a false sense of security in that these individuals may don the equipment and enter a contaminated area to initiate a rescue without considering whether their PPE will offer appropriate protection for the given hazard. Additionally, these professionals may not be adequately trained to maintain their PPE in proper condition. It was pointed out, however, that the solution to selection, use, and maintenance issues can be accomplished with training. 


\title{
Session \#2 \\ Responders and Their Respiratory Protection Needs
}

The purpose of Session \#2 was to identify responders and their function at a chemical and/or biological incident, to delineate their respiratory protection and other personal protective equipment needs, and to explore short and long-term solutions.

\section{Plenary Presentations Responders and Their Respiratory Protection Needs}

\begin{abstract}
First Presentation: Jeffrey O'Connell, CBRNC
Representing the Chemical, Biological, Radiological, and Nuclear Countermeasures subgroup (CBRNC) of the Technical Support Working Group, Mr. O'Connell briefed the audience on the latter's mission and the current projects which apply to first responders. The CBRNC subgroup is actively working to bring simple, cost effective solutions to the end users that can be utilized for effective response to chemical and/or biological incidents. The CBRNC subgroup is the primary team that focuses on chemical and biological respiratory protection and currently represents three user groups: 1) technical responders (Bomb Squad, Technical Escort Units [TEU], Chemical/Biological Incident Response Force [CBIRF], Explosive Ordinance Dis posal [EOD], and Hazardous Material Units); 2) first responders (DOJ, FEMA); and 3) special users (DOE, DOJ, and Secret Service). These users are responsible for responding to terrorist threats which commonly consist of improvised explosive and/or dispersal devices in urban environments. Examples of current CBRNC programs include the Disposable Toxic Agent Protective Suit (DTAPS), First Responders Mask, EOD suits, and a new escape mask.
\end{abstract}

In Summary, Mr. O'Connell emphasized that standards for PPE certification need to be developed by the appropriate federal agencies. These standards should include a quantitative method of evaluating the protection afforded by the entire PPE ensemble and be flexible enough to accommodate new technology and designs which offer better protection than is presently available.

\section{Second Presentation: John Eversole, Chief, Chicago Fire Department} Chief Eversole, Chicago Fire Department and IAFC representative, targeted the needs of the first responder community when faced with a terrorist threat. He vividly described how these inciden ts are currently handled on US soil and what help is needed to ensure that local responders will be capable and ready to respond effectively. Equipment that meets standards prepared by appropriate experts must be available to address these needs. Even though a threat may prove to be a hoax, each one must be treated as a real incident.

Chief Eversole was emphatic that time is running short for the nation to ensure that emergency response workers, who risk their own lives to save 
the lives of others, are adequately protected from terrorist threats. He challenged Federal agencies, to "get out of their box," and engage in this issue and to find unique and rapid solutions without getting tied up in bureaucracy and red tape. He closed with this thought: "Don't put your head on your pillow at night if you've not worked hard enough to make it better."

\section{Workgroup Discussions Responders and Their Respiratory Protection Needs}

\section{Which workers and responder groups need protection during a chemical and/ or biological incident?}

All four workgroups agreed that any responder to a chemical and/or biological incident needs to be adequately protected and that the level of protection required may vary. Information dissemination should recognize that responders include a diverse set of occupations and services: local public safety workers (firefighters, police, HazMat, bomb squad, Emergency Medical Service [EMS]); local government specialty response (Department of Environmental Protection [DEP], Department of Highways $[\mathrm{DOH}]$, county emergency planning personnel, public health officials); local utility workers (electric, gas, water); state government specialty response (national guard, state emergency planning personnel, DER, public health officials); federal law enforcement personnel [FBI, ATF]); Public Health Service (PHS), DMAT, NMRT, DMORT; private clinics and hospital workers.

\section{What kind of protection is needed?}

Several attendees said, "the priority is to develop fast, accurate, user-friendly detector systems." Detection equipment needs to have large buttons and readouts that can accommodate users in encapsulated suits. Protocols and procedures for response plans to an incident need to be developed at local levels so that all parties involved can be notified and have input. Everyone, from the first units on scene to hospital emergency room personnel, must be aware of their role in managing and mitigating an incident.

The assumption for a typical response is that the environment at an incident would be Immediately Dangerous to Life or Health (IDLH) and that the contaminant concentration would decrease with increased distance from the incident. Zone specific and/or task specific PPE, must be available. However, accurate detection equipment may not be available to establish the zones. Protection for rescue workers may differ from that required by local utility workers who provide ancillary functions: e.g., individuals entering the hot zone would require level A encapsulated suits and SCBA; utility workers and police several blocks away may only need appropriate negative-pressure or powered-air purifying respirators (PAPR). Consideration must also be given to the level of protection needed at 
decontamination operations, crime scene investigations, and triage/treatment areas as well as hospitals.

Several attendees stated that users would prefer a single canister providing adequate protection from all agents of concern. Given today's technology, this is not yet possible. A device capable of providing this type of protection would be large, cumbersome, and provide limited service time. PAPRs may not be the most practical choice if they are stored in vehicles, not properly maintained, and thus not functional when needed. Air-purifying respirators (APRs) may not be adequate because many of the chemical warfare agents have poor sensory warning properties. Either adequate end-of-service-life indicators or appropriate change-out schedules need to be developed, validated, and accepted. Many attendees noted that effective respiratory protection will need to afford multi-agent protection in the event that different agents are released simultaneously. Chemical interferences could hamper the ability of a cartridge/canister to work effectively.

Several other (non-respiratory) concerns were expressed about protective clothing items such as chemically resistant gloves and encapsulating suits. Currently no federal agency provides certification for such equipment. Attendees suggested that the ideal situation might be for NIOSH to provide leadership in the evaluation and certification of all PPE.

\section{What additional information (training, guidelines, regulations, etc.) is needed to protect users and how can it be provided?}

Workshop participants agreed that one agency needs to be responsible for collating information and making it available to the public. A short-term solution may be as simple as manufacturers providing selection guides and test data for their products so that authorities can make better selection decisions. The long-term solution is for NIOSH or another agency to certify PPE and devise a decision matrix to guide selection. Sources for this information may already exist in manufacturer's, military's, DOJ's, and other countries' guidance documents. However, these sources would have to be willing to release the best available information in a readily understandable form, even though much of it may be classified or proprietary. Currently responders consult PPE manufacturers for information on selection of equipment because they are the most knowledgeable about their own products. Thus, some participants thought manufacturers should lead the way in providing information to the end user.

The majority of the workshop participants suggested that one agency needs to bring together all the municipal organizations identified previously (Page 8) to develop a standard or generic response protocol. After developing response plans, field exercises should be scheduled that include the participation of all response personnel. Several participants said first responders should be (nationally) required to either take refresher training or meet monthly minimum training requirements, such as those specified in OSHA 29 CFR (Code of Federal Regulations) Part 1910.120. Some attendees suggested that training and information 
dissemination should be through FEMA's National Fire Academy because the appropriate relationships and curriculums already exist there. One participant suggested that all citizens of the country should have basic domestic preparedness training to promote a general level of awareness.

\section{Who are the authorities needed to define user needs? What programs must be coordinated to bring the authorities together?}

The majority of the participants said that the user's needs must be satisfied by whatever programs may be implemented; thus, the user community needs to be closely involved in this process. Others said that, while they understand the need for user involvement, users must understand it will be difficult to administer a national program that will perfectly fit every municipality's needs. The first step in this process would be for a single agency to bring together all municipal organizations and user groups in order to establish and thoroughly define the needs. This may be a service that NDPO could provide, in conjunction with its Interagency Board for Standardization and Interoperability, which is an advisory board to the NDPO and consists of officials from local, state, and federal government organizations. The Board is commissioned by the Attorney General of the United States to ensure: standardization and interoperability of equipment; research and development of advanced technologies to assist first responders at state and local levels; and the establishment and maintenance of a robust crisis and consequence management capability (refer to Appendix E for a list of members). Concurrently, agencies such as NIOSH, NIST, and SBCCOM, with experience in standards and testing for PPE, could initiate efforts to create standards-that regulatory enforcement agencies, such as OSHA, could accept and enforce-and certify PPE and detectors for use against identified threats.

Training programs need to be coordinated. Presently, basic training programs for firefighters, EMS personnel, HazMat personnel, and police exist but need to be modified to incorporate at least a basic awareness of the hazards associated with response to a suspect chemical and/or biological warfare agent release. Specialized domestic preparedness training is available for large cities from the SBCCOM Domestic Preparedness Office. Most participants suggested that one central agency, perhaps NDPO, should have control of the information provided in these training programs to insure that all potential responders receive the same basic information. The training materials need to be disseminated through the channels and authorities that have traditionally provided training (the National Fire Academy [NFA], FEMA, DOJ, OSHA, DOT).

In summary, NDPO has been established to facilitate and coordinate all efforts in training, information dissemination, and standards and policy development relating to response to terrorist incidents. The agencies traditionally responsible for providing training and technical support to responders, and which are respected and "looked to" for this type of support, must remain involved with NDPO in this effort. 


\section{What knowledge and program gaps exist? What are other perceived user protection needs?}

The largest program gap is to establish one agency that is responsible to consolidate data and references and keep track of who is doing what. Information must be accessible but not reveal confidential information that would be a detriment to national security. Another identified gap is the development of domestic response plans in the medical community. It was suggested that training delivered through $\mathrm{CDC}$ and medical societies would be beneficial.

Another identified gap involves incident communication and coordination from an incident command center. NIST's Office of Law Enforcement Standards is currently working to standardize communications systems to ensure interoperability among responders that may be involved with an incident. Response guidelines and procedures must be developed which cover the legal rights and authority that can be enforced by an Incident Commander (IC). This document should contain information about the Incident Commander's authority to contain exposed victims and the procedures that he/she must follow. Attendees acknowledged the importance of these issues and agreed that these tasks would be difficult to manage during an attack due to the associated fear and lack of knowledge. General awareness training for the domestic population could help this situation.

Users need PPE they can rely on to provide protection from chemical and/or biological threats and attendees said they would prefer to have a national endorsement of such equipment, e.g., respirators would have a NIOSH approval label to show that the product had been evaluated and will offer a minimum level of protection. User-friendly detection equipment needs to be developed. Permissible Exposure Limits (PELs) and Assigned Protection Factors (APFs) need to be established according to the level of risk that users are willing to assume based on the short- and long-term health effects of low-level exposures. PPE selection guides need to be developed and endorsed by a centralized agency.

Other discussed needs were immunizations and vaccines: Should all first responders be immunized against the hazards for which vaccines exist? Are there enough vaccines stockpiled and can they be distributed fast enough if an incident were to take place?

In summary, standards need to be developed in order to ensure minimum qualification for responder PPE protection. These standards must evaluate the performance, quality, and reliability of such equipment to minimize failures in the field. Either NDPO or some other national authority must maintain a database of chemical and/or biological counter-terrorism response information, as well as approved equipment lists, procedures, and database resources that could be easily accessed via a website and/or 800 number. Participants also expressed the need to develop user friendly resources (handbooks, CD's, diskettes, etc.) that can be disseminated to dispatch centers, hospitals, and portable incident command centers. $\square$ 


\section{Session \#3}

\section{Respirator Standards for Chemical and/or Biological Incident Responses}

The purpose of Session \#3 was to determine standards for respirators utilized for response to chemical and/or biological incidents and to discuss standards, quality assurance, and test procedures that are currently used by military and private laboratories.

\section{Plenary Presentations Respirator Standards for Chemical and/or Biological Incident Responses}

\section{First Presentation: Paul Gardner, US Army, SBCCOM}

Mr. Gardner briefed workshop attendees on the protective equipment testing programs used by the military to evaluate PPE for military and civilian applications against chemical and/or biological warfare agents. The SBCCOM has extensive expertise in the research, development, and test and evaluation of chemical and/or biological detection, decontamination, collective protection, and personal protection equipment. At the Edgewood Chemical Biological Center (ECBC), some assessments have been performed on a variety of commercial respirators and protective clothing, including both system and components level tests against agents. Examples of completed component level testing include liquid/vapor permeation, filter gas-life, and filter aerosol efficiency testing.

Both corn oil aerosol and Man-in-Simulant-Test (MIST) protection factor [PF] testing is performed to quantitatively assess the protection afforded by respirators and clothing ensemble systems in a simulated operational environment. Headform test apparatus, equipped with a breathing pump, is used to test system level performance of respirators against chemical agents such as sarin, mustard gas, cyanogen chloride, and nerve agent simulants. A wide variety of capabilities are available to evaluate the physiological effects of respirator wear on human performance.

In summary, SBCCOM possesses unique capabilities in chemical and/or biological related areas with extensive experience in the test and evaluation of both military and commercial PPE. The lack of standardized test procedures and criteria precludes qualification of respirators for civilian applications. A review of existing military and industrial standards, in conjunction with a thorough analysis of available threat data, will be required in order to establish suitable test procedures and test criteria for a national biological and chemical equipment standard. 
Second Presentation: Jack C. Sawicki, GEOMET Technologies, Inc.

Mr. Sawicki briefed the workshop on selection and test requirements for respirators. Chemical and/or biological counter-terrorism operations require a coordinated response from many responders who will utilize diverse types of respirators. To ensure safety, each respirator will require analys is and testing. Several factors must be taken into account: respiratory protection factors, chemical resistance of materials, filtration requirements for the range of exposures, training requirements, physical requirements, risk factors, and life cycle costs. PPE selection and test requirements must be directly related to risk assessment. Without real-time monitoring in place, and without an adequate threat and risk analysis, users would be required to wear level A systems for the duration of an incident. In an attack as large as the World Trade Center, there would not be enough air cylinders to support such an operation; therefore, another type of respirator is needed. Only those in the immediate release area should be required to wear an SCBA.

Mr. Sawicki believes that NIOSH can quickly develop air-purifying respirator standards, with assistance from SBCCOM, under the current regulations in 42 CFR, Part 84. Factors that need to be considered in a respirator certification program include: determining appropriate test agents and concentrations, respirator protection factors, and chemical permeation resistance of materials. A determination must be made regarding testing by live agents or simulants. He hopes it will be possible for NIOSH and the Army to develop and test respirators to reasonable criteria and produce data that will allow responders to make appropriate selection decisions.

\section{Workgroup Discussions Respirator Standards for Chemical and/or Biological Incident Responses}

What specialyspecific standards are appropriate for chemical and/or biological incidents in terms of quality, performance, and reliability?

The initial step in determining standards for equip ment is the characterization of a chemical or biological threat. For a terrorist attack, this characterization process entails determining what agents could be used, sustainable maximum concentrations, and concentration versus time profiles. Once potential agents have been identified and characterized, the most penetrating agent should be used for test challenge criteria in order to set respirator standards. It may be practical to use or simulate only the most penetrating agents for the test challenges instead of testing all of the possible agents.

Concerns were expressed that Army respirator standards developed under Army "acceptable risk" criteria-reportedly less than $1 \%$ of the force requiring medical care (not 1\% death), and less than $15 \%$ of the force showing signs of chemical effects, but not requiring medical care-would not translate well to civilian populations. There was uncertainty about what the phrase "acceptable risk" 
meant. SBCCOM representatives explained that anticipated military chemical and/or biological exposures on the battlefield are expected to be in open areas and may be at lower concentrations than might be found with a terrorist release in a confined space. Thus battlefield responders may not need SCBA, and in fact could not carry out a military battlefield mission using SCBA due to the size, weight, and re-supply needs.

The military's primary need is for a respirator that is light enough to allow completion of a mission and affords the required protection. Negative-pressure gas masks, as designed for the military, provide this capability. The risk associated with the negative-pressure mask under battlefield conditions is not with the functioning of the mask, but rather with maintaining a good facial fit under strenuous battlefield operations.

Knowing that $100 \%$ safety is an impractical requirement from a military perspective, an analysis was done to generate the minimum need in terms of winning a force-on-force battle. The analysis showed that the 1\% casualty and $15 \%$ effects level would still allow mission success; therefore, the minimum standard was set at that point. Military masks function much better than the minimum. This "acceptable risk" philosophy carries through many military situations. Warfare is an inherently dangerous environment (as is firefighting, police work, etc.). Neither the military nor the civilian community designs tanks, bullet proof vests, cars, or any other gear that provides $100 \%$ safety except at an extremely high penalty in cost or support (logistics). The current military mask allows mission completion under high level chemical attack scenarios with minimal risk, but military representatives emphasized that military respirators were designed for $100 \%$ mission completion using the respiratory capacity of a young healthy recruit and that the military does not have extensive data regarding an older civilian workforce.

Attendees discussed the need to consolidate current standards for chemical and/or biological respirator performance. The NFPA, military, and NIOSH all have their own standards for respiratory protection. A suggestion was made to merge the standards so they address user needs for all situations. Many attendees suggested that the diverse standards should be correlated and become a unified standard, using an established test procedure, wherever this can be achieved.

Newly developed standards need to be performance-based to allow flexibility for manufacturers to meet user needs and implement new technologies. Distinctly different protocols may be needed for first responders and for civilians who are merely escaping from an incident. One attendee reported that the current $85 \mathrm{Lpm}$ (liters per minute) flowrate test criterion has been known since WWI to be significantly less than the 200-300 Lpm respiratory peak flow demands commonly encountered in today's workplaces. He suggested that as long as we are using current standard testing procedures, we will never know whether respirator filters are capable of maintaining adequate protection in emergency work situations.

There is a concern that extended periods in storage degrades the performance of a facepiece and cartridge/canister. Some suggested solutions were to stamp a visible 
expiration date and storage instructions on these items or provide an end-ofservice-life indicator.

Currently, NIOSH approved particulate filters, (N, R, and P 100 filters) have the capability to filter out biological agents. Although respirators can filter out biological agents, face-seal leakage-which is affected by facial structure and facepiece models and sizes-is a significant problem. Factors such as beard growth, scars, and perspiration also affect fit and leakage. Small exposure levels to some biological agents can cause infection; therefore, identification and standardization of respirator protection factors were considered critical. Many attendees acknowledged the importance of developing and establishing a respirator fit-factor standard prior to testing respirators in order to determine an appropriate Protection Factor (PF).

It would be impractical for civilians in the escape category of an incident to undergo fit testing. Neck-dam PAPRs may be one solution for them because the seal around the neck is easier to control than face-seal leakage around a tightfitting facepiece.

\section{What regulatory or private sector programs are needed to ensure effective compliance with standards?}

There was general agreement that a certification program is required to assure the performance, reliability, and quality of chemical and/or biological respirators. Some participants suggested employing third-party labs to independently perform the testing of chemical and/or biological protective equipment. However, this would require major investment, EPA compliance (disposal/exhaust), testing expertise, acceptable security, and the ability to take delivery of and handle extremely toxic agents. Most participants suggested that third-party, independent testing laboratories be employed as facilities providing test data to NIOSH. The Institute would review and evaluate the data before approval of the respirator is granted. In this situation, third-party laboratory qualification processes must consider program performance, standard operating procedures, and appropriate ISO laboratory standards. The military has successfully used third-party labs as their agents to perform testing for research and the Chemical Demilitarization Program. Concerns were expressed that there might not be enough busines s to attract commercial labs to develop capacity to do all the testing that NIOSH performs. The DOD and NIOSH would have to be involved with implementation of third-party test lab programs. Most participants agreed that NIOSH should take the lead in any qualification of third-party labs and development of test standards.

Some participants suggested that independent testing, certification, and issuance by a third-party laboratory might be an option for respirator approvals. Participants expressed the belief that third-party labs engaging in third-party certification programs would need to be reimbursed by a Federal agency, or the manufacturer, for the cost of testing and developing laboratory capabilities. Participants debated whether a third-party certification or a NIOSH certification should be 
required. An IAFF repres entative thought that PPE certification was too se rious an issue to have a third-party laboratory certifying respirators. Inasmuch as NIOSH is the recognized certifying agency, certification should remain a governmentperformed activity.

For Chemical Warfare Agents (CWA), there are approximately eleven commercial labs as well as numerous surety agent facilities located at SBCCOM that can perform appropriate respirator and PPE testing. An SBCCOM representative suggested that SBCCOM at Edgewood perform the chemical testing, that West Desert Test Center (WDTC) at Dugway Proving Ground perform the biological testing, and that NIOSH monitor and certify the test procedures. SBCCOM representatives clarified that they certify labs for use of surety agents, but only to ensure that labs handle the agents correctly; the SBCCOM surety process does not certify the surety laboratory's test procedures. An SBCCOM scientist expressed concerns that test agent "simulants to assess media penetration may be inadequate.... Simulants may not be stopped the same way as surety agents in the micropores in the charcoal.... Simulants would be acceptable for development testing, but ultimately the respirator needs to be tested against live biological agents."

Further discussion noted that because of the extremely toxic nature of some chemical or biological agents, and the high levels of protection required, a certifying agency needs to evaluate the total protection afforded by an entire PPE ensemble. NIOSH does not currently have the authority or certification requirements to approve ensembles: the Institute only certifies respirators. One participant suggested that a third-party certifying agency should use standards developed by NFPA because NFPA standards can be developed much faster than a NIOSH regulation and can consider all the needs of the user. This point was disputed in light of the fact that several draft NFPA standards have been under review for years.

Most participants felt strongly that it is necessary to have auditing programs, operated by a consumer reporting-type organization or NIOSH, that randomly test and evaluate respirators off the shelf to assess for continued compliance after certification. NIOSH has conducted auditing programs for years under their OffThe-Shelf Product and Manufacturing Site Audit programs. Representatives from the Battelle Dugway Test Center and SBCCOM discussed how they perform similar testing to ensure the quality of military products. SBCCOM also discussed their testing under the Domestic Preparedness Program where limited commercial PPE has been tested with chemical and/or biological agents. SBCCOM data is available on the internet, but it is based on DOD test procedures which are "client specific" requirements. Therefore, the value of this data may be limited.

\section{Do other chemical and/or biological protective technologies require perfor- mance, quality, and reliability standards?}


Most participants agreed that there need to be performance, reliability, and quality standards for the following technologies: protective clothing, detectors, chemical decontamination procedures, medical treatment, bomb detection, and assay tests for biological agents.

Some standards for Chemical Protective Clothing (CPC) were reported but no universal standard was identified. The military has specifications for their CPC, and the NFPA 1991 standard is available with optional standards for Chemical Weapons testing for level A suits. Discussions explored the question as to which standard constitutes a level A protection. A participant explained that there is an EPA standard and an NFPA 1991 standard which identify level A protection, but these are not OSHA standards. NFPA has no oversight or quality checking auth ority. Level A is not a certification, it simply categorizes the hazard level at an incident. The NFPA standard specifies that an encapsulating suit must pass a positive pressure test and includes provisions for manufacturing-site audits and the possibility of different test levels or tiers: e.g., a "Level 1" approval means that the device has met some tests, a "Level 2" means that it has met more tests, and a "Level 3" means that it has met all tests.

Chemical and/or biological detectors need to be real-time instruments that can reliably identify agents. One problem with chemical and biological detectors is that current technologies cannot always detect very low concentrations of these agents and users need to be aware of an instrument's lower limit detection capabilities. Biological agents are a significant concern because of inadequate on-site detection capabilities and participants agreed that better biological weapons detectors are needed. Chemical weapons detectors are much better than biological weapon detectors and can identify the presence and concentration of multiple chemical agents in order to assess what level of protection is needed. However, for many highly toxic industrial chemical and chemical warfare agents, current detectors are not sensitive enough to measure lethal dose concentrations. Current detector standards are basically being determined by the limitations of the technology.

Decontamination (decon) is important in an attack. The individual performing a decon should know when an adequate decontamination level has been obtained, i.e., "How Clean is Clean"? When can a victim be transported and treated without creating a hazard for medical perso nnel? SBCCOM participan ts suggested that perhaps a hasty decon should be performed first and a thorough decon later, before a victim enters a hospital. SBCCOM has developed chemical permeation resistant, Deployable Medical Shelters that are under positive-pressure using filtered air. These shelters are intended to be used as mobile Army hospitals and contain an airlock area where casualties can undergo a thorough decontamination. It was suggested these Deployable Medical Shelters be retained by Army Reserve Units or National Guard Units for rapid mobilization to process and decon casualties before they enter a main hospital. Most participants felt that contaminated clothing and equipment should be disposed of instead of decon processed because the latter may yield uncertain decon results. SBCCOM representatives noted that decontamination is an operations issue as well as a technical issue. An 
additional observation was that appropriate post-attack medical treatment should consider the administration of vaccines.

\section{Which consensus and regulatory authorities need to be involved in assess- ing the effectiveness of respirators and other protective equipment?}

The following list of government, private, and consensus standard organizations were identified as serving an important role in setting PPE performance standards: NIOSH, DOD, DOJ, NFPA, OSHA, ANSI, NIST, IAFF, IAFC, PHS, the Industrial Safety Equipment Association (ISEA), the American Society for Testing and Materials (ASTM), and the National Register of Emergency Medical Technicians (NREMT). It was suggested that a few organizations take the lead and get input from the other listed organizations. Some attendees recommended that, to expedite the process, NIOSH, DOD, and OSHA should write a draft performance chemical and/or biological respiratory certification standard. NIOSH and DOD have expertise in respiratory protection and DOD has a number of test protocols, as well as information on toxicity, particle size, and other characteristics of military chemical and/or biological agents. One participant suggested that a draft standard be provided to the responder community for a one month period of public review and comment. Most participants felt that NIOSH, having the oversight role, should be the organization that would reject or accept responders' comments. Inasmuch as NIOSH does not have a standard, a draft chemical and/or biological respiratory performance standard could be used as the benchmark before going through the official rule-making process. Another approach, recommended by participants, was for NIOSH to use existing regulatory flexibility in 42 CFR Part 84. There are no requirements in 42 CFR Part 84 for challenging respirators against chemical and biological warfare agents; however, 42 CFR Part 84 provides the flexibility to add additional gases and vapors which are not listed in $\$ 84.110(\mathrm{~b})$ $\& 190(a)$.

The role of OSHA was discussed in this workgroup session. An OSHA technical representative stated, "We have always relied upon NIOSH for respirators, and we want to continue to do that." OSHA and NIOSH acknowledge that they will need the user community to report incidents of known or suspected failure of respirators. Participants asked what OSHA could do in terms of emergency rule-making? An OSHA representative stated that OSHA may be able to exhibit some flexibility through policy, variance, or other approaches short of rule-making.

SBCCOM representatives stated that SBCCOM, OSHA, and NIOSH can jointly define an operations plan to meet the need for appropriate respirator certification standards and seek funding from the NDPO or the OJP.

Participants asked SBCCOM and NIOSH representatives how the chemical and/or biological respiratory performance standards and use recommendations could be developed. An SBCCOM representative indicated that there are many variables and unknowns when developing respiratory standards against chemical and/or biological warfare agents in a civilian setting. In the industrial setting, most of the 
variables are known, e.g., hazards and their concentrations. In a terrorist incident, however, there are numerous unknowns which make it difficult to determine what class of respirator is needed to provide adequate protection. The most probable and extreme terrorism scenarios could be used to define minimum performance standards. Collaboration from the emergency responder community, manufacturers, and government enforcement agencies is needed.

Many manufactures have guidelines on selecting respirators for workers. It was suggested that NIOSH provide a decision logic for chemical and/or biological respirators. There was general agreement that most respirator guidelines should be set for a given contaminated zone; e.g., a SCBA would be suggested when the contaminant or its concentration is unknown. An SBCCOM representative remarked that exposure limits can be defined for manufacturers and chemical demilitarization plants. The Army identifies personal exposure limits as Airborne Exposure Limits (AEL). But some AEL concentration levels are below the range for many detectors. Accurate detection and monitoring to define exposure levels must be done if it's desirable to select respirators with lower levels of protection, such as negative-pressure respirators.

\section{What other issues pertain to respirators or other protective technologies?}

A major consideration, by attendees, for a chemical and/or biological respirator certification program was cost. In particular, high costs related to establishing laboratory capabilities may preclude private laboratories from participating, thus potentially limiting participation from non-governmental test facilities. Too few laboratory test facilities may delay the certification of innovative products and protection needed by responders. Other concerns were that private "for profit" test facilities may try to reduce costs by using substandard equipment, or that manufacturers may choose a lenient private test agency to ensure that their products will pass the new standards.

Other concerns noted by attendees were: laboratory setup and evaluation time, responder training, cost of protection equipment, responder commitment to a comprehensive respirator protection program, and the role of volunteer fire departments and emergency medical services.

A manufacturer of Self-Contained Self-Rescuers (SCSR) provided a brief overview on SCSR devices used by mineworkers to escape from a mine during an emergency and suggested that this technology would be suitable for escape from a chemical and/or biological incident. Other participants said that there are some instances in which air-purifying respirators could be appropriately utilized during a terrorist attack. Combination approvals such as SCBA with chemical cartridge respirators are another option reportedly being considered by some responders. A number of workgroup participants felt that there had not been enough consideration given to closed-circuit equipment in general and to protecting the general public in escape situations. It was suggested that certification standards should include protection for the public and not just responders. 


\section{Session \#4}

\section{Chemical and/or Biological Response Plans: Public Health and Medical Community Concerns}

The purpose of Session \#4 was to determine public health and medical community concerns which must be considered in developing an incident response plan; to identify public health and medical responders' unique respiratory protection needs; and to identify any existing programs that would assist in these efforts.

\section{Plenary Presentation Chemical and/or Biological Response Plans: Public Health and Medical Community Concerns}

\section{Plenary Presentation: Samuel Benson, NYC, OEM}

Mr. Benson, Project Manager for Health and Human Services at the New York City Mayor's Office of Emergency Management (OEM), outlined the unique, and situation-specific, protection concerns for public health and medical support personnel involved in treating victims from chemical and/or biological terrorist attacks. New York City has been aggressively preparing to respond to the consequences of WMD. The City started with a comprehensive analysis of the threat and resources and performed an in-depth analysis on: the emergency response system, the health care system, and the infrastructure. On the basis of the analysis, a number of protection initiatives relating to training, equipment, and exercises were undertaken. New York City also worked with federal agencies to develop a better understanding of how federal assets could be used most effectively to facilitate research and development, intelligence, response support, and logistics.

Mr. Benson briefed the audience on the tremendous effort that is required to organize and activate the different occupations and resources needed to cope with a terrorist attack. He addressed the logistics associated with each of the obvious responding groups, e.g., firefighters, Emergency Medical Technicians (EMTs), police, ambulance drivers, hospital security, doctors, and nurses. New York City recognized that the workers in the subways, trans portation systems, communication, and sanitation departments must also be considered in the response plan. Key elements for logistical requirements are PPE, antidote kits, decontamination stations, and detectors. Better PPE and detectors need to be developed; however, the design and operation of this equipment should take into account the duties that will be performed by the user. In closing, he explained that a chemical attack and a biological attack should be treated differently and that the civilian approach is distinct from a military chemical and/or biological model in mission and equipment. 


\title{
Workgroup Discussions Chemical and/or Biological Response Plans: Public Health and Medical Community Concerns
}

\author{
What personnel comprise the potentially exposed medical and public health \\ response community both on-site and offsite?
}

Participants noted that, the police, firefighters, and EMT initial responders will be potentially exposed to chemical and/or biological agents from an attack. Secondary personnel who may be potentially exposed are doctors, nurses, ambulance drivers, laboratory technicians, hospital security guards, Red Cross volunteers, industrial hygienists, and morticians. Many of the civilian casualties will self evacuate from a terrorist attack area and may, thereby, contaminate other personnel.

A biological attack dominated the discussion on this question. Mr. Benson recommended separating biological incidents from chemical incidents: they should be addressed and treated differently. Decontamination is needed in a chemical incident but is not needed in a biological attack in most cases. If individuals had a biological agent on their bodies or clothes, they would need to be decontaminated, but decontamination would not need to be applied to a person who was simply downwind of a release.

Attendees raised many additional questions which need to be answered: What are the infectious challenges needed to inflict a casualty? What is the risk of reentrainment of spores from clothing? Do we know whether an aerosolized biological agent needs to be decontaminated, particularly if found in a disseminating device such as a ventilation system? Can victims re-aerosolize enough biological spores to generate a second exposure victim (e.g., medical staff) or otherwise spread the agent?

Other discussions explored: Where should personnel be masked? Where should isolation of contaminated victims take place? How should a health care facility be informed about characteristics of the agent involved and appropriate treatment precautions?

\section{What special considerations must be addressed in developing respiratory protective ensembles for the medical and public health community?}

Most participants agreed that different exposure levels at chemical and/or biological attacks will warrant different levels of protection. Medical and public health community professions that may require personal protective equipment when treating terrorist victims are: EMTs, decontamination personnel, ambulance drivers, hospital security, orderlies, doctors, and nurses. Careful consideration should be given to the selection of respirators for doctors and nurses who will be treating victims in the emergency and recovery rooms. 
Medical personnel and the health community representatives requested guidance as to which respirator or level of protection is required based on a given exposure or threat. Many participants felt that respirators for doctors and nurses should require little to no training and maintenance, be one-size-fits-all, easy to use, nonthreatening to patients, and be able to accommodate a variety of personnel with beards, long hair, glasses, and diverse facial sizes and disfigurations. Samuel Benson added that the entire medical community needs a respirator with which a user doesn't have to be fit-tested, is easy to don, has good visibility, and is comfortable enough for extended periods of wear. Other considerations noted for medical respirators were the need to interface with medical equipment, have some form of communication capabilities, and be able to withstand long periods of storage.

A full-face view respirator was reported to be less threatening to a patient than a respirator where only a doctor's eyes can be seen and also benefits hearing impaired patients by allowing them to read a doctor's lips. Another suggested solution was the neck-dam PAPR because the seal around the neck (and leakage through it) is reportedly easier to control than face seal leakage around a tightfitting facepiece.

By the time doctors and nurses treat victims in a hospital, the victims should have undergone decontamination; therefore, the level of protection required should be lower than it was for an EMT who was first on-site before any decontamination took place.

Several participants, who were involved with developing municipal response plans, discussed the problem of how to change the mind-set of the medical community personnel who commonly do not wear respirators and are not trained in PPE. A manufacturer stated that the problem is not the respirators, but rather the motivation of the people to use them. He further stated that standards need to be changed to allow new devices to be developed, because the standards that are used today were based upon the work that was done in the 1940's.

An SBCCOM participant suggested that the Israeli government should be consulted because its military researchers developed and employed masks with good visibility in preparation for chemical and/or biological attacks.

\section{What programs, government or private, are characterizing exposures and recommending controls for civilians?}

Many governmental organizations reportedly have field and research data characterizing exposures. The DOD has groups working on chemical and biological exposure issues and has defined, and is defining, exposure limits through the Chemical Demilitarization Program. ${ }^{1}$ The CDC developed recommendations for particular exposures, and the Army is revising the se for the Chemical Demilitariza-

\footnotetext{
1 "Final Recommendation for Protecting the Health and Safety Against Potential Adverse Effects of Long-Term Exposure to Low Doses of Agents: GA, GB, VX, Mustard Agent (H, HD, T), and Lewisite (L).” Federal Register, 53 (15 March 1988):8540-8507.
} 
tion Facilities (CDF). A Chemical Stockpile Emergency Preparedness Program (CSEPP) did focus on exposures to civilians outside the CDFs and recommended PPE for responders who would be evacuating civilians. As a result of CSEPP, a great deal of data was generated on potential civilian exposures. The DOD is setting guidelines on exposure limits and consults with the National Research Council and National Academy of Sciences to enhance the credibility of the limits (these are the CSEPP limits). The US Army Center for Health Promotion and Preventive Medicine (CHPPM) should have data on lower exposure limits: PPE standards cannot be established if they are based on a detector's limitations which may only detect exposures that are higher than the recommended exposure limits. Other organizations in the government that can assist with characterizing exposure limits are OSHA, EPA, and CDC. OSHA has exposure information on toxic industrial materials and EPA provides some exposure information from its Office of Risk Assessment. The CDC has a standard for tuberculosis, but not for other biological agents. A hazard ratio that relates a toxic agent's environmental concentration to the agent's recommended exposure limits, as in the NIOSH hazard assessment model, could be used to select PPE with a equal or higher PF, but documentation of PF should be evaluated to assure the data is applicable for the intended use.

The following private organizations may have data on characterizing exposures for civilians: Battelle, American Conference of Governmental Industrial Hygienists (ACGIH), Jane's Defense Review, and the National Library of Medicine Health and Science Data Base.

Multiple participants noted that one problem with establishing PPE standards is that for many terrorist warfare agents, current detectors can only detect exposures that are higher than the recommended exposure limits.

Organizations that are recommending control policies and medical equipment for civilians are DOD, FEMA, CDC, DOT, NFPA, and OSHA. The DOD is working on warning systems for buildings; it has established procedures for isolation and decontamination of personnel, and it has mobile Deployable Medical Shelters available. The DOD representative stated that chemical decontamination is available as a sheltered airborne drop unit and perhaps the National Guard could maintain and supply these units to local areas. USAMRIID uses casualty bags to transfer patients. DOD has both policies and equipment to accommodate casualties that would be needed to control contamination during all phases of treatment. FEMA is working with cities to have emergency response plans in place wherein smaller communities would be linked to larger cities. The CDC representatives reported that the $\mathrm{CDC}$ is developing rapid verification, vaccination, and treatment guidance and support sys tems. The Department of Transportation (DOT) has mandated responsibilities for the transportation of hazardous materials and controls national policy covering the transportation of chemical and biological samples.

Participants suggested that other countries such as Israel and Sweden should be consulted to help us evaluate, and perhaps adopt, some of their emergency response procedures pertaining to chemical and/or biological attacks. 


\section{What programs are willing and able to characterize exposures and recom- mend controls for the medical and public health community?}

All the workgroups agreed that the medical community should first contact the $\mathrm{CDC}$ for information when faced with either a chemical or a biological incident. Some participants sugge sted that the CDC, USAMRIID, ACGIH, SBCCOM's Technical Escort, US Society of Toxicology, Health Science Centers throughout the country, and other national groups need to devise a nationally recognized plan for identifying and responding to a terrorist attack. Clear information was requested to guide decisions about vaccinations, post-exposure prophylaxis, etc., for responders and victims.

All groups felt that there is a great deal of medical and industrial hygiene information available about exposure limits, infectious diseases, toxicology, and probable chemical and/orbiological terrorist warfare agents that can be compiled and contribute to a national response plan.

To qualify under the NDPO grants program, many city planners, local health organizations, and Emergency Response Offices are currently preparing response plans and needs assessments for a terrorist attack. These entities have multiple questions and need resources to help develop responsible plans and identify appropriate equipment. Some of their questions are: what type of PPE should be issued to first responders and medical staff after a chemical and/or biological attack? How long must the municipality sustain the response before help can arrive? What type of medical and public health help will be required and will hospitalization and treatment systems be capable of handling the demands? Will the Directorate of Military Support (DOMS) be able to provide support to civilian programs and to what magnitude? Whose job would it be to assess hospital readiness for a chemical and/or biological attack?

To help address city officials' concerns, participants suggested the following information resources to help assess what is practical: CDC, NDPO, DOD Domestic Preparedness Training Office, IAFF, IAFC, IAPC, NIOSH, National Volunteer Fire Council, NIST, OSHA, city planners, Law Enforcement-FBI, and medical speciality societies.

Some participants challenged NIOSH to work with groups such as the National Center for Infectious Diseases (NCID), USAMRIID, PPE manufacturers, and other pertinent organizations to come up with a formal response to NYC-OEM questions which were presented in Session \#4, at this workshop. 


\section{CONCLUSIONS and SUGGESTED ACTIVITIES}

\section{Conclusions}

This workshop provided attendees ample opportunity to learn about the roles of governmental and private-sector groups involved in protecting emergency responders against chemical and/or biological terrorist incidents. Participants explored four issues: hazards associated with an incident, responders and their respiratory protection needs, respirator standards for incident responses, and incident response plans addressing medical and public health concerns associated with incidents. The following conclusions serve only to highlight the many protection issues and suggestions raised.

Chief John Eversol made everyone aware that appropriate equipment and guidelines covering all PPE issues are needed for the emergency responder community now. The Chief was joined by other attendees at the workshop in urging NIOSH to exercise whatever regulatory flexibility it possesses to test, certify, and approve respirators for chemical and/orbiological warfare agents and toxic industrial materials as quickly as possible.

Officers from municipal fire fighter companies were joined by IAFC, IAFF, and NFPA representatives in requesting NIOSH collaboration with SBCCOM to ensure that NIOSH/NFPA-approved SCBA will survive an exposure to chemical warfare agents and that critical components will not be degraded. The merging of NIOSH and SBCCOM respirator design, performance, quality assurance, and reliability standards was considered by some attendees as a good approach to provide a national chemical and/or biological respirator certification program. NIOSH and SBCCOM are developing a program of joint activities to address the issues, raised during the workshop, associated with establishing respirator standards for protection against chemical and/orbiological threats. The ability of this program to develop standards will depend upon the availability of funding. The following activities are considered essential to support a respirator certification program: establishment of a che mical and biological equipment database, respiratory equipment materials survival analysis, weapon agent and industrial chemical cartridge and canister test criteria development, threat scenario vulnerability assessment, and user guidelines development.

Some attendees requested guidance from the sponsoring agencies on how to provide NIOSH-certified APRs or PAPRs and military alternatives to SCBA for threat scenarios where contaminant concentrations appropriately dictate a lesser level of respiratory protection. Some attendees also requested NIOSH input into national domestic preparedness training programs and the development of detector technologies. 
Additional respiratory protection-related issues were requests to develop: protection factor protocols, valid APF methodologies, and respirator selection decision logic for chemical and/or biological threat scenarios.

There was general agreement that guidelines covering all PPE issues must be developed as soon as possible using the best available knowledge. Contributing agencies should then periodically review their research and investigation findings and update the guidelines as needed.

\section{Suggested Follow-Up Activities}

As requested, the conference sponsors have prepared and distributed this Workshop Report.

NIOSH and SBCCOM will continue to work with the DOD-DOJ Interagency Board for Equipment Standardization to understand the issues related to standards and qualification requirements for responder equipment.

NIOSH will collaborate with the DOD, SBCCOM, NFPA, and all interested parties to answer the issues raised about certified SCBA for use against chemical and/or biological threats.

Research is needed to address many of the concerns discussed by workshop attendees, e.g., responders need a respirator that is protective but which creates the least amount of physiological burden; respirator materials must withstand any permeation and penetration of chemical and/or biological agents, etc.

The sponsors will continue to work with other agencies to explore partnerships and areas of possible collaboration, specifically with regard to topics discussed during the workshop including: respirator standards and tests, guidance documents, and chemical and biological exposure information.

Coordination efforts should include data sharing. A great deal of information has military security classification. This information needs to be considered in establishing protection recommendations for responders and for answering the many unanswered questions raised during this workshop. One agency or group of agencies should work to get information in a readily available format for all who need it, e.g., a printed list, a website with hot buttons, or a resource guide with phone numbers, etc. Workshop sponsors will endeavor to establish a list of available information relating to the topics addressed at this meeting and make the sources of the information available to interested parties.

The information gathered during this workshop will be used to revise and upgrade agency plans for addressing respirator standards and options for respirator evaluations. Those who attended this workshop and future readers of this report should use it to gain a better understanding of the myriad issues associated with respiratory protection for emergency responders. 


\section{APPENDIX A}

\section{Plenary Speaker Abstracts and Biographies}

By order of presentation:

Mr. James A. Genovese

Mr. Andrew Bringuel II

Mr. Jeffery O'Connell

Chief John Eversole

Mr. Paul Gardner

Mr. Jack C. Sawicki

Mr. Samuel Benson 
James A. Genovese

Team Leader: Chemical/Biological Counterterrorism Team US Army's Soldier Biological Chemical Command (US SBCCOM)

Mr. James A. Genovese has served as a team leader of the Chemical/Biological Counterterrorism Team at the US Army's Soldier Biological Chemical Command (USA SBCCOM) since 1991. From 1982 to 1991, he managed multiple chemical weapons projects under the Army's Retaliatory Chemical Munitions Program. He is recognized as a national and international expert on chemical/biological terrorism and is a former chair of national and international working groups dealing with technical response to $\mathrm{CB}$ incidents. He also serves as a technical consultant and part-time hazardous materials instructor for the government's Domestic Preparedness Program.

\section{ABSTRACT \\ Response to Chemical/Biological (CB) Incidents: Sizing up the Hazards}

Effective response to chemical/biological incidents will require proactive integration of both response sectors of our government-military and civilian. This integrated framework should optimize response mission effectiveness and minimize the casualtie s to all emergency responders at any level of government. A variety of toxic materials could be utilized by the non-conventional terrorist including both chemical and biological agents. Toxic industrial chemicals, as well as military-unique $\mathrm{CB}$ hazards may pose unique challenges to our current systems of individual protection. Because our incident responders could be confronted with such a broad spectrum of hazards: chemical or biological; very toxic to mildly toxic; interior vs. exterior events, etc., it is paramount that we approach these response issues from a systems perspective.

With regard to protective posture, operations and technology need to be thoroughly ingrained in this process. Three interrelated factors should become the focus for future developments: The external environment (The WORLD), which includes the range of hazards responders may experience. The protective ensemble (The BARRIER), which involves the continuing assessment of protective system capabilities including protection factors, logistics, and others. The internal environment (YOU) that assesses the physiological effects of the responder in specific ensembles in specific operational scenarios. 


\author{
Andrew (Andy) Bringuel, II \\ FBI National Domestic Preparedness Office (NDPO)
}

Andrew Bringuel, II attended Mercer University in Atlanta and graduated from Saint Leo College with a degree in Criminal Justice. He entered duty with the FBI, February 05, 1990, and was assigned to the Birmingham Field Office's, White Collar squad where he specialized in Public Corruption, Bank Fraud, and Environmental Investigations. On October 01, 1996, Andy was assigned to the Foreign Counter-Intelligence squad working on a number of threat issues and coordinating the Awaren ess of National Issues and Response program as well as Birmingham's computer intrusion investigative team. He also served as a surveillance team coordinator, crisis negotiator, and media representative for the FBI. October 29, 1998, Andy was promoted to a supervisory position within the National Domestic Preparedness Office (NDPO) and reported for duty, February 22, 1999.

\title{
ABSTRACT \\ Overview: National Domestic Preparedness Office (NDPO)
}

The NDPO is an interagency effort to enhance coordination among federal programs offering terrorism preparedness assistance to state and local communities. The NDPO will become the clearinghouse for all weapons of mass destruction (WMD) related issues and is organized into the following programs: planning, exercises, equipment, information dissemination, and health issues. The NDPO will serve as a single program and policy coordination office for domestic preparedness programs for state and local communities.

The NDPO will continue to assist community stakeholders as well as participating state, local, and federal partners in a diligent effort to prevent, prepare, and respond to acts of terrorism involving the use of Weapons of Mass Destruction. 


\author{
Jeffrey D. O'Connell \\ Technical Support Working Group (TSWG) \\ Chemical, Biological, Radiological, Nuclear Countermeasures \\ Battelle Memorial Institute
}

Tracy Cronin of the US Navy Office of Special Technology Technical Support Working Group was invited to speak at this workshop. Due to previous commitments, she was unable to attend and asked Jeffrey O'Connell to appear and address the workshop participants on the subject of first responder needs.

Jeffrey O'Connell graduated from the United States Naval Academy in 1986, was commissioned in the Navy, and immediately reported to the Surface Warfare Officer School and the USS Rentz (FFG-46) in San Diego. Onboard the Rentz, he was assigned as Auxiliaries Officer, Ship Intelligence Officer, Combat Information Officer, and Operations Officer. During his assignment on the Rentz, he completed two deployments to the Persian Gulf including Operation Earnest Will and Praying Mantis. After his sea duty, he served as a Joint Chief of Staff Intern, acting as an action officer for the Nuclear/Chemical command and control systems, and was then assigned to the Chief of Naval Operations Office responsible for training requirements for Undersea Warfare. In 1991, Jeffrey resigned his commission and entered the naval reserves. He is currently assigned to the Chief of Naval Operations conducting assessments on the Navy's Science and Technology Programs.

Since 1992, Mr. O’Connell has been employed by Battelle Memorial Institute primarily working on Chemical/Biological Defense Programs. He has participated on the development of over 20 chemical, biological, and radiological (CBR) defensive programs including: Joint Service Integrated Light-weight Suit Technology (JSLIST), Joint Biological Point Detection System (JBPDS), Improved Chemical Agent Point Detection System (IPDS), Shipboard Collective Protection System (CPS), and Joint Service Lightweight Standoff Chemical Agent Detector (JSLSCAD). He has been instrumental in implementing the Joint Field Trials for evaluating detectors for biological warfare agent detection conducted annually at Dugway Proving Ground. His current assignment is to support the Chemical, Biological, Radiological, and Nuclear Subgroup of the Technical Support Working Group.

\title{
ABSTRACT \\ Chemical, Biological, Radiological, and Nuclear Countermeasures (CBRNC) Subgroup Briefing: Technical Support Working Group (TSWG)
}

The Technical Support Working Group (TSWG) was formed in 1986 as a result of Vice President Bush's Task Force recommendations to develop an interagency working group for combating terrorism. TSWG's mission is to conduct a national Interagency research and development $(R \& D)$ program for combating terrorism through rapid research, development, and prototyping. The main objectives 
include: providing an interagency forum to coordinate $R \& D$ requirements for combating terrorism; sponsoring R\&D not addressed by individual agencies; promoting information transfer, dual use, and commercialization; and providing a fast track and flexible program. The program guides development through Intelligence Community assessments of the terrorist threat and technical capabilities, user requirements, subgroup capabilities, and special studies. Users groups include the Departments of Defense (DOD), Energy (DOE), State (DOS), Commerce (DOC), Justice (DOJ), Transportation (DOT), Treasury, Health and Human Services (HHS), Central Intelligence Agency (CIA), Environmental Protection Agency (EPA), Federal Emergency Management Agency (FEMA), Nuclear Regulatory Commission, and United States Postal Service. The primary subgroup that focuses on chemical and biological respiratory protection is the Chemical, Biological, Radiological, and Nuclear Countermeasures (CBRNC) Subgroup.

The CBRNC Subgroup has three main user types: Technical Responders-Bomb Squad, Technical Escort Units (TEU), Chemical/Biological Incident Response Force (CBIRF), Explosive Ordinance Disposal (EOD), and Hazardous Material Units); First Responders-DOJ, FEMA; and special users-DOE, DOS, and Secret Service. These users are responsible for responding to terrorist threat devices, which commonly are improvised explosive and/or dispersal devices in urban environments.

TSWG CBRNC projects are divided into the following areas: detection and identification, protection, decontamination, and mitigation and containment. The TSWG CBRNC Subgroup meets about three times a year to review the current threat, validate on-going projects, provide a new requirement/needs list, and select and fund technologies for rapid prototyping.

Examples of current CBRNC programs include the Disposable Toxic Agent Protective Suit (DTAPS), First Responders Mask, CB EOD Suits, and a new Escape Mask. The DTAPS program develops low cost, disposable level A, B, and C protective suits with cooling for emergency response personnel (e.g., Emergency Medical Services, fire fighters, law enforcement, etc.). These suits were evaluated as a complete system with operational users. The suits are currently scheduled to be commercially available by Summer 1999. The First Responders Mask program is being developed to provide a quick donning respiratory protective system for military and civilian response teams in CB contaminated environments. The technical approach is to enhance an existing hood and blower configuration mask to allow normal operations for extended periods of time. The mask will be submitted to NIOSH for certification in 1999, and will be available through the GSA schedule. CB EOD Suits were developed to provide protection against chemical, biological and explosive threats. The suits were tested under varied environmental conditions to determine penetration resistance of high velocity droplets and vapor, integrity of materials in the presence of liquid agents/decontamination products, and protection against vaporous, aerosolized or liquid hazards. The suit is currently in operational use and commercially available. The Escape Mask Program is being developed to provide a protective hood/filter system that can last for 30 minutes which can be easily donned to escape from hazardous areas. The program evaluated commercial off-the-shelf products, and performed testing on a selected candidate. Test results were published, but due to 
lack of standards for determining escape mask effectiveness results are inconclusive. Current efforts include mask modifications and standards development.

CBRNC users have specific concerns with respect to chemical and biological respiratory protection. While current military systems provide adequate protection against the classic $\mathrm{CB}$ agents, the user community has a concern with the definition of performance specification against Toxic Industrial Chemicals (TICS). These include:

- Threat concentrations and dosages for terrorist incidents;

- Evaluation of protection factor $(\mathrm{PF})$ levels and capabilities of existing personnel protective equipment $(\mathrm{PPE})$;

- Potential requirement of several different types of filter canisters and imposing a reliance on detection systems for proper selection of protective equipment.

New respiratory protection systems need to: (a) provide extended wear; increased stay times, increased airflow rate/volume; minimized heat stress; reduced size and weight; an indication of protection time remaining; an expanded field of view-a minimum of $80 \%$ with a method of correcting vision; improved communications with respect to clarity, amplification, and hands free operation; and (b) be affordable; commercially available; compatible with existing PPE and special equipment, e.g., fire fighting equipment and night vision goggles; and manufactured with state-of-the-art materials and design features.

The certification of PPE for non-military users responding to a terrorist incident needs to include the protection factor afforded by the entire system and a scaled protection level for chemical and/or biological and toxic industrial hazards (liquid/vapor/aerosols) similar to level A to C suits, and be flexible enough to integrate innovative designs, such as the neck dam concept used in the CB First Responders Mask. Standards for certification need to be developed by the appropriate agency. 
John M. Eversole

Hazardous Materials Coordinator

Chief, Chicago Fire Department

Chief John Eversole joined the Chicago Fire Department in February, 1969 and has served on Engines, Hook and Ladders, and Squad Companies. He is a certified Master Instructor through the Office of the Illinois State Fire Marshal, as well as an instructor teaching Fire Science programs for the Chicago City Wide Colleges and the University of Illinois.

Chief Eversole has been involved in a number of special programs such as the Deep Tunnel Project and the Hazardous Incident Team (HIT). He has coordinated the development of the Confined Space/Collapse Rescue operations and has been working with the US Department of Defense in developing a civilian emergency response program for terrorism. At the present time, Chief Eversole serves as the Hazardous Materials Coordinator. Under this command he is responsible for the Hazardous Incident Team and coordinates all the Fire Department's units that make up the Hazardous Incident Task Force.

Chief Eversole is Chairman of the Hazardous Materials Committee of the International Association of Fire Chiefs and Chairman of the Hazardous Materials Professional Competency Standards Committee of the National Fire Protection Association.

\section{ABSTRACT \\ The Role of The Emergency First Responder}

Chief Eversole discussed the role of the emergency first responder to incidents involving weapons of mass destruction (WMD). He described how local responders have traditionally met the needs of their communities and adapted traditional techniques to meet these new challenges. He emphasized that today every community is threatened by WMD and that even though most threats may prove to be a hoax, each must be handled as an actual incident. The nation must act quickly to ensure that local emergency response workers, who risk their own lives to save the lives of others, are adequately protected from WMD and adequately trained to mitigate potential incidents. 


\author{
Paul D. Gardner \\ US Army Edgewood Chemical Biological Center \\ Respiratory and Collective Protection Team \\ Research and Technology Directorate \\ Aberdeen Proving Ground, MD
}

From 1982-83, Paul Gardner served as a NIOSH student intern, performing research studies to assess the aerosol collection efficiency of particulate respirator filters. In 1983, he accepted an engineering position with the US Army at the former Chemical Research and Development Center, Aberdeen Proving Ground, $\mathrm{MD}$, and for the past 15 years, he has been employed as an engineer with the US Army Edgewood Chemical Biological Center, formerly known as the Edgewood Research, Development and Engineering Center. As an established member of the Respiratory and Collective Protection Team, Research and Technology Directorate, Paul served as a principal engineer on a variety of projects involved with the design, development, and evaluation of respiratory protection equipment. Major responsibilities include identifying and evaluating new filtration technology, assessing respirator protection factor performance, investigating new respirator test methodologies, and developing novel respirator and filter design concepts for military and civilian applications. He serves as lead facilitator on several in-house and joint agency projects pertaining to the testing and evaluation of military and commercial personal protective equipment and assists in research studies to assess human performance factors and physiological stresses associated with respirator wear. He is a member of the American Industrial Hygiene Association and the International Society for Respiratory Protection.

\title{
ABSTRACT \\ Overview: SBCCOM Testing and Evaluation of CB-PPE for Civilian Applications
}

Mr. Gardner presented an overview of the type of testing performed by the US Army's Soldier and Biological Chemical Command (SBCCOM) to evaluate personal protective equipment (PPE) for military and civilian applications requiring protection against che mical and biological (CB) warfare agents. SBCCOM has extensive expertise in the research, development, and test and evaluation of $\mathrm{CB}$ detection, decontamination, collective protection, and personal protection equipment. Numerous joint agency programs involving civilian CB-PPE applications have been supported by SBCCOM over the last several years. Among the major programs supported are the Chemical Stockpile Emergency Preparedness Program (CSEPP), Domestic Preparedness Program, and the Technical Support Working Group (TSWG) on counter terrorism.

At the Edgewood Chemical Biological Center (ECBC), SBCCOM, assessments have been performed on a variety of commercial respirators and protective clothing ensembles to characterize their performance against CB agents. These evaluations include both system and component level assessments. Examples of system level 
tests include aerosol and vapor protection factor, system agent penetration and permeation, and human performance testing. Examples of component level tests include liquid/vapor permeation (swatch testing), filter gas-life, and filter aerosol efficiency testing.

Protection factor $(\mathrm{PF})$ testing is performed to quantitatively assess the protection afforded by respirators and clothing ensemble systems (e.g., chemical protective suits) in a simulated operational environment. In the aerosol PF test, a corn oil aerosol is used as the test challenge and an automated photometer system is used to measure the aerosol concentration inside the respirator or suit while the wearer undergoes an exercise routine representative of the use environment. The Man-InSimulant-Test (MIST) is another type of PF test used to determine the level of vapor protection afforded by clothing ensembles. The MIST uses methyl salicylate as a vapor challenge and passive samplers are affixed to different body locations to detect leakage. Using a body region hazard model, a whole body PF is calculated based on the individual local exposure levels (dosages) measured inside the suit.

To determine system level performance of respirators against actual chemical agents, a system test is conducted using a headform test apparatus equipped with a breathing simulator pump. Typical test challenges include sarin (GB), mustard (HD), cyanogen chloride (CK) and the nerve agent simulant dimethyl methylphosphonate (DMMP). A miniature chemical agent monitor system (MINICAMS) or a hydrogen flame emission detector (HYFED) is used to measure GB, DMMP, and HD agent concentration. Cyanogen chloride is typically measured using a gas chromatograph (GC) equipped with a flame ionization detector.

Liquid/vapor permeation testing is performed to assess the chemical agent resistance of PPE materials and components. Commonly referred to as swatch testing, test samples from masks, clothing, gloves, boots, and hoods are tested in accordance with established US Army procedures. Both vapor and liquid challenges can be tested. Typical test agents include GB and HD, although other toxic industrial chemicals and simulants can also be used. The most common test performed is the liquid challenge/vapor permeation test, whereby swatches are exposed to $10 \mathrm{~g} / \mathrm{m}^{2}$ liquid agent in a closed cell and vapor permeation profiles are determined using a MINICAMS or HYFED.

A number of test programs have been performed to assess the service life of commercial respirator filters against chemical agents. Filter cartridges and canisters are challenged against known concentrations of gases at different flow rates and humidities. Challenge gases include GB, CK, toxic industrial gases, and chemical simulants (e.g., DMMP). The tests measure the time it takes for the specific gas to penetrate the sorbent media. Respirator filters designed to provide protection against aerosols (i.e., particulate filters) are also tested for aerosol collection efficiency. Typical test aerosols include sodium chloride and dioctyl phthalate (DOP). Procedures adopted from the Code of Federal Regulations, 42 CFR Part 84, are used to assess the efficiency of particulate filters.

A wide variety of capabilities are available to evaluate the physiological effects of respirator wear on human performance: 
- Vision testing to determine field-of-view, visual acuity, and light signal detection

- Communication testing to measure speech intelligibility

- Respiratory performance to assess carbon dioxide accumulation, oxygen consumption, inhalation and exhalation resistance, and other respiration parameters

- Environmental chamber testing to assess performance at various temperatures and humidities

- Psychological and cognitive performance to quantify the psychological stress factors associated with respirator wear.

In summary, SBCCOM possesse s unique capabilities in chemical and biological related areas with extensive experience in the test and evaluation of both military and commercial PPE. The system and component level tests described above address specific performance requirements for CB protection. Test methods used to evaluate PPE items for civilian applications have primarily been adopted from standard test procedures used to assess military PPE. Test protocols and criteria have been tailored to address key performance parameters based on the threat, intended use, and specific needs of the user. The lack of standardized test procedures and criteria, however, preclude SBCCOM from "qualifying" respirators for civilian CB applications. A review of existing military and industry standards in conjunction with a thorough analysis of available threat data is required in order to establish suitable test procedures and test criteria for a national standard. The successful development of a national CB respiratory protection standard will rely on a sound understanding of the potential use scenarios, limitations of equipment, and hazards associated with emergency response operations in a CB environment. 
Jack C. Sawicki

GEOMET Technologies, Inc.

Germantown, MD

From 1980-1986 Mr. Sawicki served as Safety Specialist with the International Association of Fire Fighters, Washington, D.C., and participated in development of the first safety and health program for firefighters. From 1986-1988, he served as Program Manager, Hazardous Materials Technical Center, Dynamac Corporation, Rockville, Maryland, where he was responsible for numerous programs in hazardous materials management for the Defense Logistics Agency and as an Onsite Supervisor, he was responsible for oversight of hazardous materials response operations. From 1988-1990, he served as Senior Technical Consultant, Arthur D. Little, Inc., Cambridge, Massachusetts, where he was responsible for management of numerous chemical and/or biological environ mental protective systems research, development, testing and production programs.

Since 1990, Mr. Sawicki has served as GEOMET Technical Director, Life Support Systems, directing development of chemical and/or biological protective systems, including protective clothing, respirators, and other equipment. As GEOMET Environmental and Occupational Health and Safety Officer, he is responsible for regulatory compliance of GEOMET Chemical Surety Matériel (CSM) and biological agent (BSL-2) laboratory and Nonstockpile Demilitarization (Small Burials) Program field laboratories at Deseret and Dugway Proving Ground, Utah. He also serves as Environmental Emergency Response Team On-site Manager, and oversees incidents, such as the Riverside (California) Municipal Ho spital Emergency Department chemical release incident.

\author{
ABSTRACT \\ Respirator Test Requirements for Chemical and/or Biological \\ Counter-Terrorism Operations
}

Chemical and/or biological counter-terrorism operations require coordinated response from many responders who will utilize many types of respirators, such as those listed in the following table. 
Possible Respirators for Counter-Terrorist Use

\begin{tabular}{|l|l|l|l|l|l|}
\hline Respirator & Police & Firefighter & HazMat & EMS & Hospital \\
\hline Airline SCBA & No & Possible & Probable & Possible & Doubtful \\
\hline SCBA & Possible & Yes & Yes & Probable & No \\
\hline $\begin{array}{l}\text { 4 CFM PAPR } \\
\text { Full Face }\end{array}$ & Probable & Probable & Probable & Probable & Possible \\
\hline $\begin{array}{l}\text { 4 CFM PAPR } \\
\text { Half Mask/ } \\
\text { Hood Combo }\end{array}$ & Possible & Probable & Probable & Probable & Probable \\
\hline $\begin{array}{l}\text { 6 CFM PAPR } \\
\text { Hood }\end{array}$ & Possible & Possible & Possible & Probable & Probable \\
\hline Full Face & Probable & Possible & Possible & Possible & Possible \\
\hline Half Mask & No & No & No & Possible & Probable \\
\hline $\begin{array}{l}\text { N95/OV/AG } \\
\text { "Nuisance" } \\
\text { Mask }\end{array}$ & Doubtful & Doubtful & Doubtful & Possible & Probable \\
\hline $\begin{array}{l}\text { "Escape" } \\
\text { Hood }\end{array}$ & Probable & Possible & Possible & Probable & Probable \\
\hline Airline Hood & No & No & No & No & Possible \\
\hline
\end{tabular}

Each respirator will require analysis, and probably testing, to assure that it is appropriate for the end use. Several factors will have to be taken into account:

- Respiratory Protection

- Chemical resistance of materials

- Filtration requirements

-Threats: radioactives, organic vapors, other gases

- Risk: concentration, duration

- Training requirements

- Physical requirements (e.g., beards)

- Risk factors (separation from incident, decontamination efficacy, etc.)

- Life cycle costs

As noted above, both selection and test requirements must be directly related to risk assessment. For example, sarin and mustard gas are extremely toxic chemicals, with AELs in the range of $0.0001 \mathrm{mg} / \mathrm{m}^{3}$. Without realtime monitoring in place, and without an adequate threat and risk analysis, users would be required to wear positive pressure demand SCBA under a level A suit for the duration of an incident. It only takes consideration of the World Trade Center bombing, where hundreds of rescue workers required over 8 hours to evacuate the 
building, to recognize that there are not enough air cylinders available anywhere to support such an operation in a contaminated environment. Therefore, another type of respirator must be selected. To do so, one can utilize available data and common sense to determine what the appropriate protection can be.

Possible CW agent concentrations for various scenarios.

\begin{tabular}{|l|l|l|}
\hline $\begin{array}{l}\text { Amount released into 10,000 } \mathrm{ft}^{3} \\
\text { space, 3 air changes/hour. }\end{array}$ & [sarin] & [mustard] \\
\hline 1 Metric Ton & $2000 \mathrm{mg} / \mathrm{m}^{3}$ & $100 \mathrm{mg} / \mathrm{m}^{3}$ \\
\hline 55 gallon drum & $200 \mathrm{mg} / \mathrm{m}^{3}$ & $10 \mathrm{mg} / \mathrm{m}^{3}$ \\
\hline 5 gallon can & $20 \mathrm{mg} / \mathrm{m}^{3}$ & $1 \mathrm{mg} / \mathrm{m}^{3}$ \\
\hline \hline 1 gallon jug & $4 \mathrm{mg} / \mathrm{m}^{3}$ & $0.02 \mathrm{mg} / \mathrm{m}^{3}$ \\
\hline 1 quart bottle & $1 \mathrm{mg} / \mathrm{m}^{3}$ & $0.005 \mathrm{mg} / \mathrm{m}^{3}$ \\
\hline
\end{tabular}

Because it is unlikely that a terrorist could release more than a few gallons in an enclosed space, and because most responders would be removed from the actual scene, only those in the immediate area of a release should be required to wear SCBA. For example, in a Tokyo-like sarin release, the concentration of vapor on the train might be on the order of $10 \mathrm{mg} / \mathrm{m}^{3}$, but on the platform, it is not likely be higher than $1 \mathrm{mg} / \mathrm{m}^{3}$, and on the escalators, no more than $0.1 \mathrm{mg} / \mathrm{m}^{3}$, etc.

With this approach in mind, if we use the first table and the various selection criteria to decide where the different respirators will be used, it should be possible to determine the appropriate test conditions for each.

In addition to deciding the appropriate concentrations for testing filters with chemical agents, a critical factor is which industrial chemicals require testing. A "short list" might include phosgene, chlorine, phosphine, cyanide, cyanogen chloride, hydrogen fluoride, dimethyl sulfate, and perhaps ammonia. A longer list is probable, and must be carefully determined.

After the obvious filter requirements, equally critical is the actual protection factor for each respirator. Currently, regulations determine what value is assigned to each respirator, based on design. However, we all know that the differences between high quality respirators and "junk" are several orders of magnitude, even though both might have identical approvals. For example, the US Army gas mask can be fitted to over $95 \%$ of the adult population and achieve a protection factor of over 1,000. Some of the masks issued to the Iraqi Army-also full face respirators-have a protection factor of 10. Is there any wonder why the Iraqis did not use chemical and biological weapons? Assigning an actual range of protection factors for each model of respirator could go a long way toward making selection by responders simpler. 
A secondary factor is chemical resistance of materials. Certain materials, like silicone, allow rapid permeation of certain $\mathrm{CW}$ agents. However, it is unlikely that the concentrations that will be encountered in a terrorist attack will be as high as those inside a chemical demilitarization facility $\left(100 \mathrm{gm} / \mathrm{m}^{2}\right)$, or even in the "kill zone" of a Soviet multiple launch rocket system (MLRS) chemical barrage $\left(5-10 \mathrm{gm} / \mathrm{m}^{2}\right)$. Thus, it is likely that the liquid threats that materials should be tested to are one or more orders of magnitude lower than either of these scenarios.

In summary, it is possible for NIOSH and the Army to develop, and test to, reasonable criteria and produce data that will allow responders to make appropriate respirator selections. 


\author{
Samuel Benson \\ Mayor's Office of Emergency Management \\ New York City
}

Samuel Benson is the Project Manager for Health and Human Services at the New York City Mayor's Office of Emergency Management (OEM). Under the direction of Jerome Hauer, the Director of OEM, he is the author of the New York City Biological Terrorism Contingency Plan. Mr. Benson is a paramedic who has worked in the New York City EMS system for 14 years, 9 of them at NYC/EMS where he was one of the first paramedics trained to respond to hazardous materials incidents. Prior to coming to OEM, he spent two years as Coordinator of the Emergency Department of Columbia-Presbyterian Medical Center.

\title{
ABSTRACT \\ Preparing to Meet the Challenge of Terrorism
}

New York City has been aggressively preparing to respond to the consequences of weapons of mass destruction (WMD) terrorism for the past few years. The City started with a comprehensive analysis of the threat and current resources. Planning assumptions were established and programs put in place to develop a system of consequence management. The City performed an in-depth analysis of the emergency response system, the health care system, and the infrastructure. On the basis of the analysis, a number of initiatives (training, equipment, and exercises) were undertaken.

New York City has also worked with Federal agencies to develop a better understanding of how Federal assets could be used most effectively. Issues explored were: research and development, intelligence, federal response elements, and city/state/federal logistical interface

Mr. Benson concluded by noting that a chemical attack and a biological attack require different responses and that the civilian approach differs from the military's in data, mission, and equipment. 


\section{APPENDIX B}

\section{Registrants and Attendees}




\begin{tabular}{|c|c|c|c|}
\hline Name/Title & Company/Agency & Address & Email/Telephone/FAX \\
\hline $\begin{array}{l}\text { Backman, Lennart } \\
\text { Technical Manager } \\
\text { (R\&D Engineer) }\end{array}$ & $\begin{array}{l}\text { Safety Equipment America } \\
\text { Inc. } \\
\text { Safety Equipment Australia } \\
\text { Pty } \\
\text { Ltd }\end{array}$ & $\begin{array}{l}\text { Private Bag } 1001 \\
\text { Mona Vale NSW } 2103 \\
\text { AUSTRALIA }\end{array}$ & $\begin{array}{l}\text { lennart@seasafe.com.au } \\
\text { Phone: (02) 9910-7500 } \\
\text { FAX: (02) 9979-5364 }\end{array}$ \\
\hline $\begin{array}{l}\text { Basile, Kay } \\
\text { Secretary, Respirator } \\
\text { Branch }\end{array}$ & NIOSH, DRDS & $\begin{array}{l}1095 \text { Willowdale Road } \\
\text { Morgantown, WV 26505-2888 }\end{array}$ & $\begin{array}{l}\text { dkb1@cdc.gov } \\
\text { Phone: 304-285-5907 } \\
\text { FAX: 304-285-6030 }\end{array}$ \\
\hline $\begin{array}{l}\text { Beck, Ted D., III } \\
\text { Special Programs Manager }\end{array}$ & Biomarine & $\begin{array}{l}456 \text { Creamery Way } \\
\text { Exton, PA } 19341\end{array}$ & $\begin{array}{l}\text { ted.beck@neutronicsinc.com } \\
\text { Phone: 610-524-8800 } \\
\text { FAX: 610-524-8807 }\end{array}$ \\
\hline $\begin{array}{l}\text { Benson, Linda } \\
\text { Quality Assurance } \\
\text { Specialist } \\
\text { Respirator Branch }\end{array}$ & NIOSH, DRDS & $\begin{array}{l}1095 \text { Willowdale Road } \\
\text { Morgantown, WV 26505-2888 }\end{array}$ & $\begin{array}{l}\text { lrb4@cdc.gov } \\
\text { Phone: 304-285-5988 } \\
\text { FAX: 304-285-6030 }\end{array}$ \\
\hline $\begin{array}{l}\text { Benson, Samuel } \\
\text { Project Manager }\end{array}$ & $\begin{array}{l}\text { New York City Office of } \\
\text { Emergency Management }\end{array}$ & $\begin{array}{l}7 \text { World Trade Center } \\
23^{\text {rd }} \text { Floor } \\
\text { New York City, NY } 10048\end{array}$ & $\begin{array}{l}\text { sbenson@oem.cn.ci.nyc.ny.us } \\
\text { Phone: 212-442-4823 } \\
\text { FAX: 212-442-8885 }\end{array}$ \\
\hline $\begin{array}{l}\text { Berardinelli, Steve, Sr. } \\
\text { Protective Equipment Team }\end{array}$ & NIOSH, DSR & $\begin{array}{l}1095 \text { Wilowdale Road } \\
\text { Morgantown, WV 26505-2888 }\end{array}$ & $\begin{array}{l}\text { ssb2@cdc.gov } \\
\text { Phone: 304-285-5975 } \\
\text { FAX: 304-285-6047 }\end{array}$ \\
\hline $\begin{array}{l}\text { Berndtsson, Goran, CEO } \\
\text { (Joint Managing Director) }\end{array}$ & $\begin{array}{l}\text { Safety Equipment America } \\
\text { Inc. } \\
\text { Safety Equipment Australia } \\
\text { Pty } \\
\text { Ltd }\end{array}$ & $\begin{array}{l}\text { Private Bag } 1001 \\
\text { Mona Vale NSW } 2103 \\
\text { AUSTRALIA }\end{array}$ & $\begin{array}{l}\text { goranb@sea.com.au } \\
\text { Phone: 202-448-9562 } \\
\text { FAX: 203-488-9562 }\end{array}$ \\
\hline $\begin{array}{l}\text { Birkner, Jeff } \\
\text { Vice President Technical } \\
\text { Services }\end{array}$ & Moldex-Metric, Inc. & $\begin{array}{l}10111 \text { West Jefferson Blvd. } \\
\text { Culver City, CA } 90232\end{array}$ & $\begin{array}{l}\text { 110742.2575@Compuserve.com } \\
\text { Phone: 310-837-6500 x700 } \\
\text { FAX: 310-837-2024 }\end{array}$ \\
\hline $\begin{array}{l}\text { Blanchet, Michael } \\
\text { Industrial Hygienist }\end{array}$ & Vermont Department of Health & $\begin{array}{l}\text { P.O. Box } 70 \\
108 \text { Cherry St. } \\
\text { Burlington, VT } 05402\end{array}$ & $\begin{array}{l}\text { Phone: 802-865-7730 } \\
\text { FAX: 802-865-7745 }\end{array}$ \\
\hline
\end{tabular}




\begin{tabular}{|c|c|c|c|}
\hline Name/Title & Company / Agency & Address & Email/Telephone / FAX \\
\hline $\begin{array}{l}\text { Bobetich, Kenneth V. } \\
\text { Product Group Manager } \\
\text { Air-Purifying Respirators }\end{array}$ & MSA & $\begin{array}{l}\text { P.O. Box } 426 \\
\text { Pittsburgh, PA } 15230-0426\end{array}$ & $\begin{array}{l}\text { Ken.Bobetich@msanet.com } \\
\text { Voice Mail 1-800-759-6423 *3148 } \\
\text { Phone: 1-800-MSA-2222 } \\
\text { FAX: 1-800-967-0398 }\end{array}$ \\
\hline $\begin{array}{l}\text { Bollinger, Nancy } \\
\text { Deputy Director, HELD }\end{array}$ & NIOSH, HELD & $\begin{array}{l}1095 \text { Willowdale Road } \\
\text { Morgantown, WV 26505-2888 }\end{array}$ & $\begin{array}{l}\text { njb3@cdc.gov } \\
\text { Phone: 304-285-6121 } \\
\text { FAX: 304-285-6126 }\end{array}$ \\
\hline Booth, Donald* & & $\begin{array}{l}123 \text { Heron Lane } \\
\text { Beaver, WV } 25813\end{array}$ & \\
\hline $\begin{array}{l}\text { Bowyer, Matt } \\
\text { Quality Assurance } \\
\text { Specialist } \\
\text { Respirator Branch }\end{array}$ & NIOSH, DRDS & $\begin{array}{l}1095 \text { Willowdale Road } \\
\text { Morgantown, WV 26505-2888 }\end{array}$ & $\begin{array}{l}\text { mqb2@cdc.gov } \\
\text { Phone: 304-285-5991 } \\
\text { FAX: 304-285-6030 }\end{array}$ \\
\hline $\begin{array}{l}\text { Bradley, Janice C. } \\
\text { Technical Director }\end{array}$ & $\begin{array}{l}\text { ISEA } \\
\text { The Safety Equipment } \\
\text { Association }\end{array}$ & $\begin{array}{l}1901 \text { N. Moore St. } \\
\text { Arlington, VA } 22209\end{array}$ & $\begin{array}{l}\text { Jcbradley@safetycentral.org } \\
\text { Phone: 703-525-1695 } \\
\text { FAX: 703-528-2148 }\end{array}$ \\
\hline $\begin{array}{l}\text { Brey, Dr. Larry } \\
\text { Research Specialist }\end{array}$ & $\begin{array}{l}\text { 3M Occupational Health and } \\
\text { Environmental Safety Division }\end{array}$ & $\begin{array}{l}\text { 3M Center } \\
\text { 260-3B-11 } \\
\text { Maplewood, MN } 55144\end{array}$ & $\begin{array}{l}\text { labrey@mmm.com } \\
\text { Phone: 651-736-3069 } \\
\text { FAX: 651-73302277 }\end{array}$ \\
\hline $\begin{array}{l}\text { Bringuel II, Andrew } \\
\text { Supervisory Special Agent }\end{array}$ & $\begin{array}{l}\text { FBI } \\
\text { National Domestic } \\
\text { Preparedness Office (NDPO) }\end{array}$ & $\begin{array}{l}935 \text { Pennsylvania Ave. } \\
\text { Washington, DC } 20535\end{array}$ & $\begin{array}{l}\text { abringue@leo.gov } \\
\text { Phone: 202-324-0275 } \\
\text { FAX: 202-324-8686 }\end{array}$ \\
\hline $\begin{array}{l}\text { Bryant, Jeff } \\
\text { Industrial Hygienist } \\
\text { Risk Evaluation Branch }\end{array}$ & NIOSH, EID & $\begin{array}{l}\text { TAFT Center } \\
4676 \text { Columbia Parkway } \\
\text { Cincinnati, OH } 45226\end{array}$ & $\begin{array}{l}\text { cjb7@cdc.gov } \\
\text { Phone: 513-533-8251 } \\
\text { FAX: 513-533-8560 }\end{array}$ \\
\hline $\begin{array}{l}\text { Calvert, Cathy } \\
\text { Engineering Technician } \\
\text { Respirator Branch }\end{array}$ & NIOSH, DRDS & $\begin{array}{l}1095 \text { Willowdale Road } \\
\text { Morgantown, WV 26505-2888 }\end{array}$ & $\begin{array}{l}\text { cac3@cdc.gov } \\
\text { Phone: 304-285-5735 } \\
\text { FAX: 304-285-6030 }\end{array}$ \\
\hline $\begin{array}{l}\text { Campbell, Lee E. } \\
\text { Surety Operations }\end{array}$ & US Army, SBCCOM & $\begin{array}{l}\text { ATTN: AMSSB-REN-SO } \\
\text { APG, MD } 21010-5424\end{array}$ & $\begin{array}{l}\text { lecampbe@sbccom.apgea.army.mil } \\
\text { Phone: 410-436-3555 } \\
\text { FAX: 410-436-3003 }\end{array}$ \\
\hline
\end{tabular}




\begin{tabular}{|c|c|c|c|}
\hline Name/Title & Company/Agency & Address & Email/Telephone/FAX \\
\hline $\begin{array}{l}\text { Campbell, Don, Ph.D. } \\
\text { Senior Scientist } \\
\text { Laboratory Investigations } \\
\text { Branch }\end{array}$ & NIOSH, DRDS & $\begin{array}{l}1095 \text { Willowdale Road } \\
\text { Morgantown, WV 26505-2888 }\end{array}$ & $\begin{array}{l}\text { dlc2@cdc.gov } \\
\text { Phone: 304-285-5953 } \\
\text { FAX: 304-285-6321 }\end{array}$ \\
\hline $\begin{array}{l}\text { Carson, Guy B. } \\
\text { Vice President - Operations }\end{array}$ & CSE Corporation & $\begin{array}{l}600 \text { Seco Road } \\
\text { Monroeville, PA } 15146\end{array}$ & $\begin{array}{l}\text { gbc@csecorporation.com } \\
\text { Phone: 412-856-9200 } \\
\text { FAX: 412-856-9203 }\end{array}$ \\
\hline $\begin{array}{l}\text { Cashen, Ray } \\
\text { Legal Counsel }\end{array}$ & ISEA & $\begin{array}{l}1901 \text { N. Moore St. } \\
\text { Arlington, VA } 22209\end{array}$ & $\begin{array}{l}\text { isea@safetycentral.org } \\
\text { Phone: 703-525-1695 } \\
\text { FAX: 703-528-2148 }\end{array}$ \\
\hline $\begin{array}{l}\text { Clash, Bruce R. } \\
\text { Public Affairs Director }\end{array}$ & ISEA & $\begin{array}{l}1901 \text { N. Moore St. } \\
\text { Arlington, VA } 22209\end{array}$ & $\begin{array}{l}\text { isea@safetycentral.org } \\
\text { Phone: 703-525-1695 } \\
\text { FAX: 703-528-2148 }\end{array}$ \\
\hline $\begin{array}{l}\text { Cobes, John W., III } \\
\text { Sr. Chemical Engineer }\end{array}$ & $\begin{array}{l}\text { MSA } \\
\text { Safety Products Engineering }\end{array}$ & $\begin{array}{l}\text { P.O. Box } 439 \\
\text { Pittsburgh, PA } 15230-0439\end{array}$ & $\begin{array}{l}\text { John.Cobes@MSAnet.com } \\
\text { Phone: 412-776-7854 } \\
\text { FAX: 412-776-7743 }\end{array}$ \\
\hline $\begin{array}{l}\text { Coffey, Chris } \\
\text { Senior Research Chemist } \\
\text { Laboratory Investigations } \\
\text { Branch }\end{array}$ & NIOSH, DRDS & $\begin{array}{l}1095 \text { Willowdale Road } \\
\text { Morgantown, WV 26505-2888 }\end{array}$ & $\begin{array}{l}\text { ccc3@cdc.gov } \\
\text { Phone: 304-285-5958 } \\
\text { FAX: 304-285-6321 }\end{array}$ \\
\hline $\begin{array}{l}\text { Cohee, Donald R. (P.E.) } \\
\text { Director, Research \& } \\
\text { Technology }\end{array}$ & ILC Dover, Inc & $\begin{array}{l}\text { P.O. Box } 266 \\
\text { Frederica, DE } 19946\end{array}$ & $\begin{array}{l}\text { coheed@ilcdover.com } \\
\text { Phone: 302-335-3911 Ext } 281 \\
\text { FAX: 302-335-0762 }\end{array}$ \\
\hline $\begin{array}{l}\text { Colton, Craig E. (CIH) } \\
\text { Sr. Technical Service } \\
\text { Specialist }\end{array}$ & $\begin{array}{l}\text { 3M Occupational Health \& } \\
\text { Environmental Safety Div. }\end{array}$ & $\begin{array}{l}\text { 3M Center, Building 260-3B-09 } \\
\text { St. Paul, MN 55144-1000 }\end{array}$ & $\begin{array}{l}\text { cecolton@mmm.com } \\
\text { Phone: 651-733-6297 } \\
\text { FAX: 651-736-7344 }\end{array}$ \\
\hline $\begin{array}{l}\text { Crosby, David \& Ferguson, } \\
\text { James - Consultants }\end{array}$ & Air Techniques & $\begin{array}{l}\text { P.O. Box } 987 \\
\text { Millersville, MD } 21108\end{array}$ & $\begin{array}{l}\text { technologymarketing@juno.com } \\
\text { Phone: 410-987-9111 } \\
\text { FAX: 410-987-6392 }\end{array}$ \\
\hline $\begin{array}{l}\text { Davis, Wayne K. } \\
\text { Product Manager, Masks }\end{array}$ & US Army, SBCCOM & $\begin{array}{l}\text { ATTN:AMSSB-PM-RNN-P } \\
\text { APG, MD } 21010-5424\end{array}$ & $\begin{array}{l}\text { wkdavis@apgea.army.mil } \\
\text { Phone: 410-436-1776 } \\
\text { FAX: 410-436-4185 }\end{array}$ \\
\hline
\end{tabular}




\begin{tabular}{|c|c|c|c|}
\hline Name/Title & Company/Agency & Address & Email/Telephone/FAX \\
\hline $\begin{array}{l}\text { Dawson, John } \\
\text { Senior Instructor }\end{array}$ & Seattle Fire Department & $\begin{array}{l}301 \text { 2nd Ave., S. } \\
\text { Seattle, WA } 98104\end{array}$ & $\begin{array}{l}\text { alan.vickery@seattle.cl.wa.us } \\
\text { Phone: 206-386-1895 } \\
\text { FAX: 206-386-1545 }\end{array}$ \\
\hline $\begin{array}{l}\text { Decker, Richard W., II } \\
\text { Team Leader, Joint Service } \\
\text { General Purpose Mask }\end{array}$ & US Army, SBCCOM & $\begin{array}{l}\text { ATTN: AMMSB-PM-RNN-G } \\
\text { APG, MD } 21010-5424\end{array}$ & $\begin{array}{l}\text { rwdecker@sbccom.apgea.army.mil } \\
\text { Phone: 410-436-6024 } \\
\text { FAX: 410-436-2149 }\end{array}$ \\
\hline $\begin{array}{l}\text { Decker, John } \\
\text { Industrial Hygienist, M.S., } \\
\text { C.I.H. }\end{array}$ & $\begin{array}{l}\text { CDC } \\
\text { Special Programs Group }\end{array}$ & $\begin{array}{l}4770 \text { Buford Hwy, NE (F-16) } \\
\text { Atlanta, GA } 30341-3724\end{array}$ & $\begin{array}{l}\text { jad4@cdc.gov } \\
\text { Phone: } 770-488-7619 \\
\text { FAX: } 770-488-4127\end{array}$ \\
\hline $\begin{array}{l}\text { Deitchman, Scott D., MD, } \\
\text { MPH - Medical Officer }\end{array}$ & $\mathrm{NIOSH} / \mathrm{CDC}$ & $\begin{array}{l}\text { Bldg. 1, Room 3047, M/S D-40 } \\
1600 \text { Clifton Road, N.E. } \\
\text { Atlanta, GA } 30333\end{array}$ & $\begin{array}{l}\text { sed2@cdc.gov } \\
\text { Phone: 404-639-1534 } \\
\text { FAX: 404-639-0919 }\end{array}$ \\
\hline $\begin{array}{l}\text { Dower, John } \\
\text { Industrial Hygienist } \\
\text { Respirator Branch }\end{array}$ & NIOSH, DRDS & $\begin{array}{l}1095 \text { Willowdale Road } \\
\text { Morgantown, WV 26505-2888 }\end{array}$ & $\begin{array}{l}\text { jmd2@cdc.gov } \\
\text { Phone: 304-285-5954 } \\
\text { FAX: 304-285-6030 }\end{array}$ \\
\hline $\begin{array}{l}\text { Drobnick, Rudy A. } \\
\text { Product Engineer }\end{array}$ & Dalloz Safety & $\begin{array}{l}\text { 2nd \& Washington Sts. } \\
\text { P.O. Box } 622 \\
\text { Reading, PA 19603-0622 }\end{array}$ & $\begin{array}{l}\text { willson8dd@talon.net } \\
\text { Phone: 610-376-6161 } \\
\text { FAX: 610-371-7867 }\end{array}$ \\
\hline $\begin{array}{l}\text { Duffy, Laura M. } \\
\text { Research Associate }\end{array}$ & $\begin{array}{l}\text { Div. Of Military Science \& } \\
\text { Technology, Board on Army } \\
\text { Science \& Technology }\end{array}$ & $\begin{array}{l}\text { National Academy of Sciences } \\
2101 \text { Constitution Ave., NW HA258 } \\
\text { Washington, DC } 20418\end{array}$ & $\begin{array}{l}\text { lduffy@nas.edu } \\
\text { Phone: 202-334-1976 } \\
\text { FAX: 202-334-2620 }\end{array}$ \\
\hline $\begin{array}{l}\text { Duffy, Richard* } \\
\text { Dir., Occupational Health } \\
\text { \& Safety }\end{array}$ & $\begin{array}{l}\text { International Association of } \\
\text { Fire } \\
\text { Fighters }\end{array}$ & $\begin{array}{l}1750 \text { New York Ave., NW } \\
\text { Washington, DC } 20006\end{array}$ & $\begin{array}{l}\text { iaffohs@aol.com } \\
\text { Phone: 202-737-8484 } \\
\text { FAX: 202-737-8418 }\end{array}$ \\
\hline $\begin{array}{l}\text { Dunkleberger, Jay } \\
\text { Project Director }\end{array}$ & NY State Department of Health & $\begin{array}{l}2 \text { University Place } \\
\text { Albany, NY } 12223\end{array}$ & $\begin{array}{l}\text { jdd08@health.state.ny.us } \\
\text { Phone: 518-458-6458 } \\
\text { FAX: 518-458-6434 }\end{array}$ \\
\hline $\begin{array}{l}\text { Durney, Doug * } \\
\text { Director of Marketing }\end{array}$ & ILC Dover, Inc. & $\begin{array}{l}\text { One Moonwalker Road } \\
\text { Frederica, DE 19946-2080 }\end{array}$ & $\begin{array}{l}\text { durneyd@ilcdover.com } \\
\text { Phone: 302-335-3011 Ext. } 260 \\
\text { FAX: 302-325-1620 }\end{array}$ \\
\hline $\begin{array}{l}\text { El-Ayouby, Nadia } \\
\text { Industrial Hygienist } \\
\text { Protective Equipment Team }\end{array}$ & NIOSH, DSR & $\begin{array}{l}1095 \text { Willowdale Road } \\
\text { Morgantown, WV 26505-2888 }\end{array}$ & $\begin{array}{l}\text { nae7@cdc.gov } \\
\text { Phone: 304-285-5910 } \\
\text { FAX: 304-285-6047 }\end{array}$ \\
\hline
\end{tabular}




\begin{tabular}{|c|c|c|c|}
\hline Name/Title & Company/Agency & Address & Email/Telephone / FAX \\
\hline $\begin{array}{l}\text { English, Dave } \\
\text { Consultant }\end{array}$ & ILC Dover, Inc & $\begin{array}{l}68 \text { West High St. } \\
\text { Getteysburg, PA } 17325\end{array}$ & $\begin{array}{l}\text { dmenglis@cvn.net } \\
\text { Phone: 717-334-4032 } \\
\text { FAX: 717-334-4032 }\end{array}$ \\
\hline $\begin{array}{l}\text { Eversole, John M. } \\
\text { Chief }\end{array}$ & $\begin{array}{l}\text { Chicago Fire Department } \\
558 \text { West DeKoven Street } \\
\text { Chicago, IL } 60607\end{array}$ & $\begin{array}{l}558 \text { West DeKoven Street } \\
\text { Chicago, IL } 60607\end{array}$ & $\begin{array}{l}\text { Phone: 312-747-6582 } \\
\text { FAX: 312-727-6582 }\end{array}$ \\
\hline $\begin{array}{l}\text { Fargo, Christine } Z \text {. } \\
\text { Tech. Projects Coordinator }\end{array}$ & ISEA & $\begin{array}{l}1901 \text { North Moore Street } \\
\text { Arlington, VA 22209-1762 }\end{array}$ & $\begin{array}{l}\text { czfargo@safetycentral.org } \\
\text { Phone: 703-525-1695 } \\
\text { FAX: 703-528-2148 }\end{array}$ \\
\hline $\begin{array}{l}\text { Fatah, Al } \\
\text { Physical Scientist }\end{array}$ & NIST-OLES & $\begin{array}{l}100 \text { Bureau Drive, \#8102 } \\
\text { Gaithersburg, MD 20899-8102 }\end{array}$ & $\begin{array}{l}\text { alim.fatah@nist.gov } \\
\text { Phone: 301-975-2757 } \\
\text { FAX: 301-948-0978 }\end{array}$ \\
\hline $\begin{array}{l}\text { Fecteau, Keith } \\
\text { Technical Director } \\
\text { Respiratory Protection }\end{array}$ & Aearo Company & $\begin{array}{l}90 \text { Mechanic St } \\
\text { Southbridge, MA } 01550\end{array}$ & $\begin{array}{l}\text { keith_fecteau@aearo.com } \\
\text { Phone: 508-764-5787 } \\
\text { FAX: 508-764-3187 }\end{array}$ \\
\hline $\begin{array}{l}\text { Ferguson, James \& } \\
\text { Crosby, David } \\
\text { Consultants }\end{array}$ & Air Techniques & $\begin{array}{l}\text { P.O. Box } 987 \\
\text { Millersville, MD } 21108\end{array}$ & $\begin{array}{l}\text { technologymarketing@juno.com } \\
\text { Phone: 410-987-9111 } \\
\text { FAX: 410-987-6392 }\end{array}$ \\
\hline $\begin{array}{l}\text { Foley, Stephen } \\
\text { Sr. Fire Service Specialist }\end{array}$ & National Fire Protection Assoc. & $\begin{array}{l}1 \text { Batterymarch Park } \\
\text { Quincy, MA 02269-9101 }\end{array}$ & $\begin{array}{l}\text { sfoley@NFPA.org } \\
\text { Phone: 617-984-7468 } \\
\text { FAX: 617-984-7056 }\end{array}$ \\
\hline $\begin{array}{l}\text { Forrest, Emma* } \\
\text { Safety Professional }\end{array}$ & US Army, SBCCOM & $\begin{array}{l}\text { Aberdeen Proving Ground } \\
\text { Maryland 21010-5423 }\end{array}$ & $\begin{array}{l}\text { Phone: 410-436-2585 } \\
\text { FAX: 410-436-6692 }\end{array}$ \\
\hline $\begin{array}{l}\text { Fritch, William M.* } \\
\text { Joint Service General } \\
\text { Purpose Mask }\end{array}$ & US Army, SBCCOM & $\begin{array}{l}\text { ATTN: AMSSB-PM-RNN-G } \\
\text { APG, MD } 21010-5424\end{array}$ & $\begin{array}{l}\text { wmfritch@sbccom.a pgea.army.mil } \\
\text { Phone: 410-436-7966 } \\
\text { FAX: 410-436-2149 }\end{array}$ \\
\hline $\begin{array}{l}\text { Frund, Zane, Dr. } \\
\text { Manager of Chemical } \\
\text { Research }\end{array}$ & MSA & $\begin{array}{l}302 \text { Walden Road } \\
\text { Cranberry Township, PA } 16066\end{array}$ & $\begin{array}{l}\text { zane.frund@msanet.com } \\
\text { Phone: 724-776-7780 } \\
\text { FAX: 724-776-7742 }\end{array}$ \\
\hline
\end{tabular}




\begin{tabular}{|c|c|c|c|}
\hline Name/Title & Company/Agency & Address & Email/Telephone/FAX \\
\hline $\begin{array}{l}\text { Game, Steve } \\
\text { Health Statistician } \\
\text { Field Studies Branch }\end{array}$ & NIOSH, DRDS & $\begin{array}{l}1095 \text { Willowdale Road } \\
\text { Morgantown, WV 26505-2888 }\end{array}$ & $\begin{array}{l}\text { srg0@cdc.gov } \\
\text { Phone: 304-285-6113 } \\
\text { FAX: 304-285-5820 }\end{array}$ \\
\hline $\begin{array}{l}\text { Gardner, Paul } \\
\text { Respiratory Protection } \\
\text { Team }\end{array}$ & US Army, SBCCOM & $\begin{array}{l}\text { ATTN: AMSSB-RTT-PR } \\
\text { Aberdeen Proving Ground } \\
\text { Edgewood, MD 21010-5424 }\end{array}$ & $\begin{array}{l}\text { pdgardner@sbccom.apgea.army.mil } \\
\text { Phone: 410-436-6692 } \\
\text { FAX: 410-436-3141 }\end{array}$ \\
\hline $\begin{array}{l}\text { Genovese, Jim } \\
\text { Chemical Biological } \\
\text { Terrorism Team }\end{array}$ & US Army, SBCCOM & $\begin{array}{l}\text { ATTN: SCBRD-RTB } \\
\text { Edgewood, MD } 21010\end{array}$ & $\begin{array}{l}\text { jagenove@sbccom.apgea.army.mil } \\
\text { Phone: 410-436-1951 } \\
\text { FAX: 410-436-8205 }\end{array}$ \\
\hline Giordano, Ross* & $\begin{array}{l}\text { Shalon Chemical Industries, } \\
\text { Ltd. }\end{array}$ & $\begin{array}{l}25 \text { Nahmani St. } \\
\text { Tel-Aviv } 65795 \\
\text { Israel }\end{array}$ & $\begin{array}{l}\text { shalon@netvision.net.il } \\
\text { Phone: 972-3-6291225 } \\
\text { Phone: sellstrom-847-358-2000 } \\
\text { FAX: 847-358-8564 }\end{array}$ \\
\hline \multicolumn{4}{|l|}{ Goch, David* } \\
\hline $\begin{array}{l}\text { Golias, Emil } \\
\text { Sr. Industrial Hygienist }\end{array}$ & OSHA & $\begin{array}{l}1781 \text { South } \\
300 \text { West } \\
\text { Salt Lake City, UT } 84165\end{array}$ & $\begin{array}{l}\text { emil.golias@osha-slg.gov } \\
\text { Phone: 801-487-0251 } \\
\text { FAX: 801-487-1190 }\end{array}$ \\
\hline $\begin{array}{l}\text { Graham, Stephen } \\
\text { Technical Manager }\end{array}$ & $\begin{array}{l}\text { US Army-CHPPM } \\
\text { Center for Health Promotion } \\
\text { and Preventive Medicine }\end{array}$ & $\begin{array}{l}5158 \text { Blackhawk Road } \\
\text { APG, MD } 21010-5422\end{array}$ & $\begin{array}{l}\text { stephen.graham@apg.amedd. } \\
\text { army.mil } \\
\text { Phone: 410-436-2559 } \\
\text { FAX: 410-436-5471 }\end{array}$ \\
\hline $\begin{array}{l}\text { Granatiero, Nino M. } \\
\text { Director of Research and } \\
\text { Development }\end{array}$ & North Safety Products & $\begin{array}{l}2000 \text { Plainfield Pike } \\
\text { Cranston, RI 02921 }\end{array}$ & $\begin{array}{l}\text { nino.granatiero@northsafety.com } \\
\text { Phone: 401-275-2423 } \\
\text { FAX: 401-946-7560 }\end{array}$ \\
\hline $\begin{array}{l}\text { Haack, Brad, Ph.D.* } \\
\text { Microbiologist }\end{array}$ & Dugway Proving Ground & $\begin{array}{l}\text { Dugway Proving Ground } \\
\text { Dugway, UT } 84022\end{array}$ & $\begin{array}{l}\text { haack@dugway-emh3.army.mil } \\
\text { Phone: 435-831-3005 } \\
\text { FAX: 435-831-5716 }\end{array}$ \\
\hline $\begin{array}{l}\text { Hale, John P. } \\
\text { Training - Publications - } \\
\text { Technical Services - } \\
\text { Consulting }\end{array}$ & Respirator Support Services & $\begin{array}{l}2028 \text { Virts Lane } \\
\text { Jefferson, MD 21755-8801 }\end{array}$ & $\begin{array}{l}\text { jph@radix.net } \\
\text { Phone: 301-834-6008 } \\
\text { FAX: 301-682-3731 }\end{array}$ \\
\hline
\end{tabular}




\begin{tabular}{|c|c|c|c|}
\hline Name/Title & Company/Agency & Address & Email/Telephone/FAX \\
\hline Harkness, Allen 'Ira' & $\begin{array}{l}\text { US Navy Costal System } \\
\text { Station }\end{array}$ & $\begin{array}{l}\text { Code A53 } \\
\text { Panama City, FL } 32407\end{array}$ & $\begin{array}{l}\text { harknessia@ncsc.navy.mil } \\
\text { Phone: 850-235-5480 } \\
\text { FAX: 820-234-4775 }\end{array}$ \\
\hline $\begin{array}{l}\text { Haskell, Bill } \\
\text { Engineering \& Technical } \\
\text { Liaison }\end{array}$ & $\begin{array}{l}\text { SBCCOM } \\
\text { Natick Soldier Center }\end{array}$ & $\begin{array}{l}\text { Kansas Street } \\
\text { ATTN: AMSSB-RSC-BB(N) } \\
\text { Natick, MA } 01760\end{array}$ & $\begin{array}{l}\text { whaskell@natick-a med02.army.mil } \\
\text { Phone: 508-233-4477 } \\
\text { FAX: 508-233-4352 }\end{array}$ \\
\hline Haskew, Mark & Lockheed Martin & $\begin{array}{l}\text { Y-12 Plant } \\
\text { P.O. Box } 2009 \\
\text { Oak Ridge, TN 37831-8092 }\end{array}$ & $\begin{array}{l}\text { hwm@orln.gov } \\
\text { Phone: 723-576-8588 } \\
\text { FAX: 423-576-2367 }\end{array}$ \\
\hline $\begin{array}{l}\text { Hearl, Frank } \\
\text { Deputy Director, DRDS }\end{array}$ & NIOSH, DRDS & $\begin{array}{l}1095 \text { Willowdale Road } \\
\text { Morgantown, WV 26505-2888 }\end{array}$ & $\begin{array}{l}\text { fjh1@cdc.gov } \\
\text { Phone: 304-285-6131 } \\
\text { FAX: 304-285-5861 }\end{array}$ \\
\hline $\begin{array}{l}\text { Herring, Ron } \\
\text { Marketing Manager } \\
\text { Safety Products Division }\end{array}$ & MSA & $\begin{array}{l}\text { P.O. Box } 426 \\
\text { Pittsburgh, PA 15230-0426 }\end{array}$ & $\begin{array}{l}\text { ron.herring@msanet.com } \\
\text { Phone: 412-967-3318 } \\
\text { FAX: 412-967-3521 }\end{array}$ \\
\hline $\begin{array}{l}\text { Hewett, Dan } \\
\text { Sanitarian } \\
\text { Field Studies Branch }\end{array}$ & NIOSH, DRDS & $\begin{array}{l}1095 \text { Willowdale Road } \\
\text { Morgantown, WV 26505-2888 }\end{array}$ & $\begin{array}{l}\text { djh0@cdc.gov } \\
\text { Phone: 304-285-6306 } \\
\text { FAX: 304-285-5796 }\end{array}$ \\
\hline $\begin{array}{l}\text { Hewett, Paul, Ph.D. } \\
\text { Acting Senior IH, IH Team } \\
\text { Field Studies Branch }\end{array}$ & NIOSH, DRDS & $\begin{array}{l}1095 \text { Willowdale Road } \\
\text { Morgantown, WV 26505-2888 }\end{array}$ & $\begin{array}{l}\text { pah2@cdc.gov } \\
\text { Phone: 304-285-6259 } \\
\text { FAX: 304-285-5861 }\end{array}$ \\
\hline $\begin{array}{l}\text { Higgins, Kathleen* } \\
\text { Director }\end{array}$ & NIST-OLES & $\begin{array}{l}100 \text { Bureau Drive } \\
\text { Gaithersburg, MD 20899-8102 }\end{array}$ & $\begin{array}{l}\text { kathleen.higgins@nist.gov } \\
\text { Phone: 301-975-2757 } \\
\text { FAX: 301-948-0978 }\end{array}$ \\
\hline $\begin{array}{l}\text { Hoague, Michael } \\
\text { Vice President of } \\
\text { Operations }\end{array}$ & Micronel Technologies, Inc. & $\begin{array}{l}\text { Micronel Safety } \\
5703 \text { Industry Lane } \\
\text { Frederick, MD } 21704\end{array}$ & $\begin{array}{l}\text { mhoague@micronelsafety.com } \\
\text { Phone: 301-624-5600 } \\
\text { FAX: 301-624-5688 }\end{array}$ \\
\hline $\begin{array}{l}\text { Hoffman, Bill } \\
\text { Air Purifying Respirator } \\
\text { Section } \\
\text { Respirator Branch }\end{array}$ & NIOSH, DRDS & $\begin{array}{l}1095 \text { Willowdale Road } \\
\text { Morgantown, WV 26505-2888 }\end{array}$ & $\begin{array}{l}\text { wah0@cdc.gov } \\
\text { Phone: 304-285-5907 } \\
\text { FAX: 304-285-6047 }\end{array}$ \\
\hline
\end{tabular}




\begin{tabular}{|c|c|c|c|}
\hline Name/Title & Company / Agency & Address & Email/Telephone/FAX \\
\hline $\begin{array}{l}\text { Holmquist-Brown, } \\
\text { Thomas W. } \\
\text { Senior Development } \\
\text { Engineer }\end{array}$ & $\begin{array}{l}\text { 3M Occupational Health and } \\
\text { Environmental Safety Division }\end{array}$ & $\begin{array}{l}\text { 3M Center } \\
2606-B 11 \\
\text { St. Paul, MN } 55144\end{array}$ & $\begin{array}{l}\text { twholmquist-brown@mmm.com } \\
\text { Phone: 651-736-4558 } \\
\text { FAX: 651-733-4055 }\end{array}$ \\
\hline $\begin{array}{l}\text { Hood, Tara } \\
\text { ASPH Fellow } \\
\text { Field Studies Branch }\end{array}$ & NIOSH, DRDS & $\begin{array}{l}1095 \text { Willowdale Road } \\
\text { Morgantown, WV 26505-2888 }\end{array}$ & $\begin{array}{l}\text { tjh5@cdc.gov } \\
\text { Phone: 304-285-5734 } \\
\text { FAX: 304-285-5796 }\end{array}$ \\
\hline Hughes, John & $\begin{array}{l}\text { New York City Office of } \\
\text { Emergency Management }\end{array}$ & $\begin{array}{l}206 \text { Ridge Road } \\
\text { Goshen, NY } 10924\end{array}$ & $\begin{array}{l}\text { jhughes@oem.cn.ci.nyc.ny.us } \\
\text { Phone: 212-442-2044 } \\
\text { FAX: 212-442-8885 }\end{array}$ \\
\hline $\begin{array}{l}\text { Jensen, Paul } \\
\text { Chief, Laboratory Research } \\
\text { Branch }\end{array}$ & NIOSH, DRDS & $\begin{array}{l}1095 \text { Willowdale Road } \\
\text { Morgantown, WV 26505-2888 }\end{array}$ & $\begin{array}{l}\text { pej4@cdc.gov } \\
\text { Phone: 304-285-5790 } \\
\text { FAX: 304-285-5861 }\end{array}$ \\
\hline $\begin{array}{l}\text { Johnson, William R. } \\
\text { Principal Analyst } \\
\text { Deputy Project Officer }\end{array}$ & $\begin{array}{l}\text { Consequence Management } \\
\text { Program Integration Office } \\
\text { Director of Military Support }\end{array}$ & $\begin{array}{l}400 \text { Army Pentagon } \\
\text { Washington, DC 20310-0400 }\end{array}$ & $\begin{array}{l}\text { johnsonw@hqda.aoc.army. } \\
\text { pentagon.mil } \\
\text { Phone: 703-695-2283 } \\
\text { FAX: 703-697-3147 }\end{array}$ \\
\hline $\begin{array}{l}\text { Jonmaire, Paul W., Ph.D. } \\
\text { Director of Health \& Safety }\end{array}$ & $\begin{array}{l}\text { Ecology \& Environment, Inc. } \\
\text { EPA Contractor }\end{array}$ & $\begin{array}{l}\text { Buffalo Corporate Center } \\
368 \text { Pleasantview Drive } \\
\text { Lancaster, NY } 14086\end{array}$ & $\begin{array}{l}\text { jonmaire@enc.com } \\
\text { Phone: 716-684-8060 } \\
\text { FAX: 716-684-0844 }\end{array}$ \\
\hline $\begin{array}{l}\text { Kjellbert, Bengt } \\
\text { President }\end{array}$ & $\begin{array}{l}\text { Safety Equipment of America, } \\
\text { Inc }\end{array}$ & $\begin{array}{l}8 \text { Ramblewood Drive } \\
\text { Branford, CT } 06405\end{array}$ & $\begin{array}{l}\text { bengtk@sea.com.au } \\
\text { Phone: 203-488-9562 } \\
\text { FAX: 203-488-9562 }\end{array}$ \\
\hline $\begin{array}{l}\text { Kochenderfer, Vance* } \\
\text { Product Engineer }\end{array}$ & Cairnsair & $\begin{array}{l}11 \text { Parkway Circle } \\
\text { New Castle, DE } 19720\end{array}$ & $\begin{array}{l}\text { cairns@cairnsair.com } \\
\text { Phone: 302-325-1190 } \\
\text { FAX: 302-325-1198 }\end{array}$ \\
\hline $\begin{array}{l}\text { Konsin, Larry } \\
\text { Marketing Manager }\end{array}$ & $\begin{array}{l}\text { International Safety } \\
\text { Instruments }\end{array}$ & $\begin{array}{l}922 \text { Hurricane Shoals Road } \\
\text { Lawrenceville, GA } 30043\end{array}$ & $\begin{array}{l}\text { mktmgr@intsafety.com } \\
\text { Phone: 770-962-2552 } \\
\text { FAX: 770-963-2797 }\end{array}$ \\
\hline $\begin{array}{l}\text { Kreiss, Kay } \\
\text { Chief, Field Studies Branch }\end{array}$ & NIOSH, DRDS & $\begin{array}{l}1095 \text { Willowdale Road } \\
\text { Morgantown, WV 26505-2888 }\end{array}$ & $\begin{array}{l}\text { kxk2@cdc.gov } \\
\text { Phone: 304-285-5800 } \\
\text { FAX: 304-285-5861 }\end{array}$ \\
\hline
\end{tabular}




\begin{tabular}{|c|c|c|c|}
\hline Name/Title & Company/Agency & Address & Email/Telephone/FAX \\
\hline $\begin{array}{l}\text { Kullman, Greg } \\
\text { Industrial Hygienist } \\
\text { Field Studies Branch }\end{array}$ & NIOSH, DRDS & $\begin{array}{l}1095 \text { Willowdale Road } \\
\text { Morgantown, WV 26505-2888 }\end{array}$ & $\begin{array}{l}\text { gjk1@cdc.gov } \\
\text { Phone: 304-285-5959 } \\
\text { FAX: 304-285-5796 }\end{array}$ \\
\hline $\begin{array}{l}\text { Langley, John } \\
\text { Sr. Vice President } \\
\text { Research \& Development }\end{array}$ & $\begin{array}{l}\text { Kappler Protective Apparel } \\
\& \text { Fabrics }\end{array}$ & $\begin{array}{l}\text { P.O. Box } 490 \\
\text { Guntersville, AL } 35976\end{array}$ & $\begin{array}{l}\text { jlangley@kappler.com } \\
\text { Phone: 800-750-3768 ext. } 4135 \\
\text { FAX: 256-582-2263 }\end{array}$ \\
\hline $\begin{array}{l}\text { Laye, Randolph G. } \\
\text { Team Leader, Chemical } \\
\text { Weapons Improved } \\
\text { Response Team }\end{array}$ & US Army SBCCOM & $\begin{array}{l}\text { ATTN: AMSSB-RCB-CI } \\
\text { Aberdeen Proving Ground } \\
\text { Edgewood, MD 21010-5424 }\end{array}$ & $\begin{array}{l}\text { randolph.laye@sbccom.apgea. } \\
\text { army.mil } \\
\text { Phone: 410-436-7446 } \\
\text { FAX: 410-436-4684 }\end{array}$ \\
\hline $\begin{array}{l}\text { Levinson, Andrew } \\
\text { Health \& Safety Specialist }\end{array}$ & $\begin{array}{l}\text { International Association of } \\
\text { Fire Fighters }\end{array}$ & $\begin{array}{l}1750 \text { NY Ave., N.W. } \\
\text { Washington, DC } 20006\end{array}$ & $\begin{array}{l}\text { alev@erols.com } \\
\text { Phone: 202-737-8484 } \\
\text { FAX: 202-737-8418 }\end{array}$ \\
\hline $\begin{array}{l}\text { Liddiard, Vincent M., M.S. } \\
\text { Program Manager } \\
\text { Project Scientist }\end{array}$ & $\begin{array}{l}\text { Battelle } \\
\text { Defense Technology/National } \\
\text { Security Div. }\end{array}$ & $\begin{array}{l}\text { Dugway Proving Ground } \\
\text { STEDP-WD-L } \\
\text { Dugway, UT } 84022\end{array}$ & $\begin{array}{l}\text { vlidd@dugway-em h3.army.mil } \\
\text { Phone: 435-831-3013 } \\
\text { FAX: 435-831-5716 }\end{array}$ \\
\hline $\begin{array}{l}\text { Lieberman, George } \\
\text { Physical Scientist }\end{array}$ & NIST-OLES & $\begin{array}{l}100 \text { Bureau Drive } \\
\text { Gaithersburg, MD 20899-8102 }\end{array}$ & $\begin{array}{l}\text { george.lieberman@nist.gov } \\
\text { Phone: 301-975-2757 } \\
\text { FAX: 301-948-0978 }\end{array}$ \\
\hline $\begin{array}{l}\text { Lindsay, Robert S. } \\
\text { Surety Operations }\end{array}$ & SBCCOM & $\begin{array}{l}\text { ATTN: AMSSB-REN-SO } \\
\text { APG, MD } 21010-5424\end{array}$ & $\begin{array}{l}\text { rslinday@sbccom .apgea.army.mil } \\
\text { Phone: 410-436-2801 } \\
\text { FAX: 410-436-3003 }\end{array}$ \\
\hline $\begin{array}{l}\text { Lord, Carter } \\
\text { Physical Scientist }\end{array}$ & NIST-OLES & $\begin{array}{l}\text { 100 Bureau Drive } \\
\text { M/S 8102, Bldg. 225, Rm. } 9323 \\
\text { Gaithersburg, MD 20899-8102 }\end{array}$ & $\begin{array}{l}\text { carter.1loyd@nist.gov } \\
\text { Phone: 301-975-2757 } \\
\text { FAX: 301-948-0978 }\end{array}$ \\
\hline $\begin{array}{l}\text { Louchart, Randy } \\
\text { Public Health Advisor }\end{array}$ & $\begin{array}{l}\text { Bioterriorism Preparedness, } \\
\text { NCID }\end{array}$ & $\begin{array}{l}\text { M/S E-51 } \\
1600 \text { Clifton Road, NE } \\
\text { Atlanta, GA } 30333\end{array}$ & $\begin{array}{l}\text { rd14@cdc.gov } \\
\text { Phone: 404-639-0393 } \\
\text { FAX: 404-639-0382 }\end{array}$ \\
\hline $\begin{array}{l}\text { Ly, Hung } \\
\text { Safety Engineer } \\
\text { Risk Management } \\
\text { Safety/Surety Office }\end{array}$ & US Army SBCCOM & $\begin{array}{l}\text { ATTN: AMSSB-RCB-RS } \\
\text { APG, MD } 21010-5424\end{array}$ & $\begin{array}{l}\text { hgly@sbccom.apgea.army.mil } \\
\text { Phone: 410-436-2492 } \\
\text { FAX: 410-436-4445 }\end{array}$ \\
\hline
\end{tabular}




\begin{tabular}{|c|c|c|c|}
\hline Name/Title & Company / Agency & Address & Email/Telephone / FAX \\
\hline $\begin{array}{l}\text { Maloney, Charlene } \\
\text { Publications Mgt Specialist } \\
\text { Information Dissemination } \\
\text { Team }\end{array}$ & NIOSH, EID & $\begin{array}{l}\text { TAFT Center } \\
4676 \text { Columbia Parkway } \\
\text { Cincinnati, OH } 45226\end{array}$ & $\begin{array}{l}\text { cbm1@cdc.gov } \\
\text { Phone: 513-533-8380 } \\
\text { FAX: 513-533-8588 }\end{array}$ \\
\hline $\begin{array}{l}\text { Martin, Frank } \\
\text { RDEC Homeland Defense } \\
\text { Program Coordinator }\end{array}$ & US Army, SBCCOM & $\begin{array}{l}\text { ATTN: AMSSB-RAS } \\
\text { APG, MD 21010-5424 }\end{array}$ & $\begin{array}{l}\text { famartin@sbccom .apgea.army.mil } \\
\text { Phone: 410-436-8930 } \\
\text { FAX: 410-436-2014 }\end{array}$ \\
\hline $\begin{array}{l}\text { McCarthy, Robert T. } \\
\text { Chief Fire Technical } \\
\text { Programs Branch }\end{array}$ & $\begin{array}{l}\text { United States Fire } \\
\text { Administration } \\
\text { Federal Emergency } \\
\text { Management Agency }\end{array}$ & $\begin{array}{l}16825 \text { South Seton Avenue } \\
\text { Emmitsburg, MD } 21727\end{array}$ & $\begin{array}{l}\text { bob.mccarthy@fema.gov } \\
\text { Phone: 301-447-1130 - office } \\
\text { FAX: 301-447-1219 }\end{array}$ \\
\hline $\begin{array}{l}\text { McDermott, Glen D., M.D., } \\
\text { MPH } \\
\text { Occupational \& Aerospace } \\
\text { Medicine } \\
\text { Lieutenant Colonel, Medical } \\
\text { Corps }\end{array}$ & US Army HQ & $\begin{array}{l}\text { ATTN:AMC-AMCSG-O } \\
5001 \text { Eisenhower Avenue } \\
\text { Alexandria, VA 22333-0001 }\end{array}$ & $\begin{array}{l}\text { gmcdermott@hqa mc.army.mil } \\
\text { Phone: 703-617-0239 } \\
\text { FAX: 703-617-8558 }\end{array}$ \\
\hline $\begin{array}{l}\text { McDowell, Tom } \\
\text { Respirator Branch }\end{array}$ & NIOSH, DRDS & $\begin{array}{l}1095 \text { Willowdale Road } \\
\text { Morgantown, WV 26505-2888 }\end{array}$ & $\begin{array}{l}\text { tom0@cdc.gov } \\
\text { Phone: 304-285-5907 } \\
\text { FAX: 304-285-6030 }\end{array}$ \\
\hline $\begin{array}{l}\text { McStravick, John D. } \\
\text { Vice President }\end{array}$ & SCOTT Health \& Safety & $\begin{array}{l}309 \text { W. Crowell St. } \\
\text { Monroe NC } 28112\end{array}$ & $\begin{array}{l}\text { jstravic@scottaviation.com } \\
\text { Phone: } 704-282-8401 \\
\text { FAX: 704-282-8424 }\end{array}$ \\
\hline Mellow, Charlene M., Ph.D. & $\begin{array}{l}\text { US Army Soldier, Biological, } \\
\text { Chemical Command }\end{array}$ & $\begin{array}{l}\text { Kansas Street } \\
\text { Natick, MA } 01760\end{array}$ & $\begin{array}{l}\text { cmellow@natick-am ed02.army.mil } \\
\text { Phone: 508-233-5825 } \\
\text { FAX: 508-233-5521 }\end{array}$ \\
\hline $\begin{array}{l}\text { Merinar, Tim } \\
\text { General Engineer } \\
\text { Respirator Branch }\end{array}$ & NIOSH, DRDS & $\begin{array}{l}1095 \text { Willowdale Road } \\
\text { Morgantown, WV 26505-2888 }\end{array}$ & $\begin{array}{l}\text { trm2@cdc.gov } \\
\text { Phone: 304-285-5965 } \\
\text { FAX: 304-285-6030 }\end{array}$ \\
\hline $\begin{array}{l}\text { Metzler, Rich } \\
\text { Chief, Respirator Branch }\end{array}$ & NIOSH, DRDS & $\begin{array}{l}1095 \text { Willowdale Road } \\
\text { Morgantown, WV 26505-2888 }\end{array}$ & $\begin{array}{l}\text { rwm0@cdc.gov } \\
\text { Phone: 304-285-5907 } \\
\text { FAX: 304-285-6030 }\end{array}$ \\
\hline
\end{tabular}




\begin{tabular}{|c|c|c|c|}
\hline Name/Title & Company/Agency & Address & Email/Telephone/FAX \\
\hline Moore, Mike & OSHA & $\begin{array}{l}\text { P.O. Box } 77314 \\
\text { Washington, DC } 20013\end{array}$ & $\begin{array}{l}\text { mike.moore@osha-no.osha.gov } \\
\text { Phone: 202-693-2190 } \\
\text { FAX: 202-693-1681 }\end{array}$ \\
\hline $\begin{array}{l}\text { Morgan, Nancy } \\
\text { Quality Assurance } \\
\text { Specialist } \\
\text { Respirator Branch }\end{array}$ & NIOSH, DRDS & $\begin{array}{l}1095 \text { Willowdale Road } \\
\text { Morgantown, WV 26505-2888 }\end{array}$ & $\begin{array}{l}\text { nlm2@cdc.gov } \\
\text { Phone: 304-285-5961 } \\
\text { FAX: 304-285-6030 }\end{array}$ \\
\hline $\begin{array}{l}\text { Moulton, Craig } \\
\text { Industrial Hygienist }\end{array}$ & OSHA & $\begin{array}{l}\text { P.O. Box } 77314 \\
\text { Washington, DC } 20013\end{array}$ & $\begin{array}{l}\text { craig.moulton@osha-no.osha.gov } \\
\text { Phone: 202-693-2190 } \\
\text { FAX: 202-693-1681 }\end{array}$ \\
\hline Muller, John, MD & NIOSH,DRDS & $\begin{array}{l}1095 \text { Willowdale Road } \\
\text { Morgantown, WV 26505-2888 }\end{array}$ & $\begin{array}{l}\text { Phone: } 304-285-5751 \\
\text { FAX: 304-285-5861 }\end{array}$ \\
\hline $\begin{array}{l}\text { Murphy, Robert A., CWO3, } \\
\text { USMC } \\
\text { Emergency Services Officer }\end{array}$ & $\begin{array}{l}\text { II MEF US Marine Corps } \\
\text { Chem Bio Incident Response } \\
\text { Force (CBIRF) }\end{array}$ & $\begin{array}{l}\text { PSC Box } 20165 \\
\text { Camp Lejeune, NC } 28542\end{array}$ & $\begin{array}{l}\text { murphyra@iimef.usmc.mil } \\
\text { Phone: 910-451-9092 } \\
\text { FAX: 910-451-3085 }\end{array}$ \\
\hline Nelson, Pete & TSI, Incorporated & $\begin{array}{l}\text { P.O. Box } 64394 \\
\text { St. Paul, MN } 55164\end{array}$ & $\begin{array}{l}\text { pnelson@tsi.com } \\
\text { Phone: 800-677-2708 } \\
\text { FAX: 612-490-3860 }\end{array}$ \\
\hline $\begin{array}{l}\text { Newcomb, William E. } \\
\text { Director of Regulatory } \\
\text { Affairs \& } \\
\text { Standards Development }\end{array}$ & NORTH Safety Products & $\begin{array}{l}2000 \text { Plainfield Pike } \\
\text { Cranston, RI } 02921\end{array}$ & $\begin{array}{l}\text { bill.newcomb@northsafety.com } \\
\text { Phone: 401-275-2445 } \\
\text { FAX: 401-942-9360 }\end{array}$ \\
\hline $\begin{array}{l}\text { Nieman, Sandy } \\
\text { Secretary, IH Team } \\
\text { Field Studies Branch }\end{array}$ & NIOSH, DRDS & $\begin{array}{l}1095 \text { Willowdale Road } \\
\text { Morgantown, WV 26505-2888 }\end{array}$ & $\begin{array}{l}\text { skn1@cdc.gov } \\
\text { Phone: 304-285-6077 } \\
\text { FAX: 304-285-5820 }\end{array}$ \\
\hline $\begin{array}{l}\text { O'Connell, Jeffrey D. } \\
\text { Program Area Manager } \\
\text { Naval NBC Defense } \\
\text { Systems }\end{array}$ & $\begin{array}{l}\text { Battelle } \\
\text { Crystal City Operations }\end{array}$ & $\begin{array}{l}1725 \text { Jefferson Davis Hwy, Suite } 600 \\
\text { Arlington, VA 22202-4172 }\end{array}$ & $\begin{array}{l}\text { oconnelj@battelle.org } \\
\text { Phone: 703-413-8866 } \\
\text { FAX: 703-413-8880 }\end{array}$ \\
\hline $\begin{array}{l}\text { Palmieri, Mark J. } \\
\text { OSSP. Hax. Mat. Tech. } \\
\text { Regional Manager }\end{array}$ & $\begin{array}{l}\text { DuPont } \\
\text { Tyvek \& Tychem Protective } \\
\text { Apparel }\end{array}$ & $\begin{array}{l}1433 \text { Grandin Avenue } \\
\text { Pittsburgh, PA } 15216\end{array}$ & $\begin{array}{l}\text { palmiem@csoc.lvs.dupont.com } \\
\text { Phone: 800-500-7480 } \\
\text { FAX: 412-341-6709 }\end{array}$ \\
\hline
\end{tabular}




\begin{tabular}{|c|c|c|c|}
\hline Name/Title & Company / Agency & Address & Email/Telephone/FAX \\
\hline $\begin{array}{l}\text { Palya, Frank M. } \\
\text { General Engineer } \\
\text { Respirator Branch }\end{array}$ & NIOSH, DRDS & $\begin{array}{l}1095 \text { Willowdale Road } \\
\text { Morgantown, WV 26505-2888 }\end{array}$ & $\begin{array}{l}\text { fcp2@cdc.gov } \\
\text { Phone: 304-285-5907 } \\
\text { FAX: 304-285-6030 }\end{array}$ \\
\hline $\begin{array}{l}\text { Parker, Jay } \\
\text { Laboratory Manager }\end{array}$ & E.D. Bullard Co. & $\begin{array}{l}1898 \text { Safetyway } \\
\text { Cynthiana, KY } 41031\end{array}$ & $\begin{array}{l}\text { jay_parker@bullard.com } \\
\text { Phone: 606-234-6611 } \\
\text { FAX: 606-234-8987 }\end{array}$ \\
\hline $\begin{array}{l}\text { Pavelchak, Nick } \\
\text { Research Scientist }\end{array}$ & $\begin{array}{l}\text { New York State Department of } \\
\text { Health }\end{array}$ & $\begin{array}{l}2 \text { University Place, Rm. } 155 \\
\text { Albany, NY } 12203\end{array}$ & $\begin{array}{l}\text { nxpo2@health.state.ny.us } \\
\text { Phone: 518-458-6228 } \\
\text { FAX: 518-458-6200 }\end{array}$ \\
\hline $\begin{array}{l}\text { Pease, Tom } \\
\text { Manager of Business } \\
\text { Development }\end{array}$ & Gentex Corporation & $\begin{array}{l}\text { P.O. Box } 315 \\
\text { Carbondale, PA } 18407\end{array}$ & $\begin{array}{l}\text { tpease@gentexcorp.com } \\
\text { Phone: 570-282-8511 } \\
\text { FAX: 570-282-8555 }\end{array}$ \\
\hline $\begin{array}{l}\text { Peterson, Jeff } \\
\text { Engineering Technician } \\
\text { Respirator Branch }\end{array}$ & NIOSH, DRDS & $\begin{array}{l}1095 \text { Willowdale Road } \\
\text { Morgantown, WV 26505-2888 }\end{array}$ & $\begin{array}{l}\text { jap3@cdc.gov } \\
\text { Phone: 304-285-5960 } \\
\text { FAX: 304-285-6030 }\end{array}$ \\
\hline $\begin{array}{l}\text { Peterson, LT Ed } \\
\text { Lead Instructor }\end{array}$ & Seattle Fire Department & $\begin{array}{l}301 \text { 2nd Ave., S. } \\
\text { Seattle, WA } 98104\end{array}$ & $\begin{array}{l}\text { alan.vickery@seattle.cl.wa.us } \\
\text { Phone: 206-386-1895 } \\
\text { FAX: 206-386-1545 }\end{array}$ \\
\hline $\begin{array}{l}\text { Pfriem, Dale B. } \\
\text { President, CEO }\end{array}$ & ICS, Inc. & $\begin{array}{l}9337 \text { Ravenna Road, Unit M } \\
\text { Twinsburg, OH } 44087\end{array}$ & $\begin{array}{l}\text { dpfriem@intcert.com } \\
\text { Phone: 330-405-1418 } \\
\text { FAX: 330-405-1420 }\end{array}$ \\
\hline $\begin{array}{l}\text { Pickett-Harner, Molly } \\
\text { Writer/Editor }\end{array}$ & NIOSH, DRDS,CIA & $\begin{array}{l}1095 \text { Willowdale Road } \\
\text { Morgantown, WV 26505-2888 }\end{array}$ & $\begin{array}{l}\text { mop1@cdc.gov } \\
\text { Phone: 304-285-5778 } \\
\text { FAX: 304-285-5861 }\end{array}$ \\
\hline $\begin{array}{l}\text { Pizatella, Tim, MS } \\
\text { Deputy Director, DSR }\end{array}$ & NIOSH, DSR & $\begin{array}{l}1095 \text { Willowdale Road } \\
\text { Morgantown, WV 26505-2888 }\end{array}$ & $\begin{array}{l}\text { tjp2@cdc.gov } \\
\text { Phone: 304-285-5894 } \\
\text { FAX: 304-285-6046 }\end{array}$ \\
\hline $\begin{array}{l}\text { Poulson, Sandy } \\
\text { Quality Assurance } \\
\text { Specialist } \\
\text { Respirator Branch }\end{array}$ & NIOSH, DRDS & $\begin{array}{l}1095 \text { Willowdale Road } \\
\text { Morgantown, WV 26505-2888 }\end{array}$ & $\begin{array}{l}\text { skp1@cdc.gov } \\
\text { Phone: 304-285-6197 } \\
\text { FAX: 304-285-6030 }\end{array}$ \\
\hline
\end{tabular}




\begin{tabular}{|c|c|c|c|}
\hline Name/Title & Company/Agency & Address & Email/Telephone/FAX \\
\hline Reinert, Bruce & Los Alamos Laboratory & $\begin{array}{l}\text { M/S K553 } \\
\text { Los Alamos, NM } 87545\end{array}$ & $\begin{array}{l}\text { reinertb@lanl.gov } \\
\text { Phone: 505-667-5775 } \\
\text { FAX: 505-665-3689 }\end{array}$ \\
\hline $\begin{array}{l}\text { Resha, Chris } \\
\text { Associate Product Manager }\end{array}$ & Kappler & $\begin{array}{l}\text { P.O. Box } 18 \\
\text { Grimes Drive } \\
\text { Guntersville, AL } 35976\end{array}$ & $\begin{array}{l}\text { info@kappler.com } \\
\text { Phone: 800-750-3768 ext. } 4032 \\
\text { FAX: 256-582-2706 }\end{array}$ \\
\hline $\begin{array}{l}\text { Rice, Kirk } \\
\text { Physical Scientist }\end{array}$ & NIST-OLES & $\begin{array}{l}\text { Bldg. 225, Room A367 } \\
\text { 100 Bureau Drive } \\
\text { Gaithersburg, MD 20899-8102 }\end{array}$ & $\begin{array}{l}\text { kirk.rice@nist.gov } \\
\text { Phone: 301-975-2757 } \\
\text { FAX: 301-948-0978 }\end{array}$ \\
\hline $\begin{array}{l}\text { Roberts, Tim, CIH, CSP* } \\
\text { Industrial Hygienist }\end{array}$ & Lawrence Livermore Nat'l Lab & $\begin{array}{l}7000 \text { East Ave., L-384 } \\
\text { Livermore, CA 94550-9234 }\end{array}$ & $\begin{array}{l}\text { roberts15@1lnl.gov } \\
\text { Phone: 925-423-3981 } \\
\text { FAX: 925-422-5270 }\end{array}$ \\
\hline $\begin{array}{l}\text { Roberts, Paul J., Jr. } \\
\text { Emergency Systems } \\
\text { Analyst } \\
\text { Decision \& Info Sciences } \\
\text { Division }\end{array}$ & $\begin{array}{l}\text { ARGONNE National } \\
\text { Laboratory }\end{array}$ & $\begin{array}{l}955 \text { L'Enfant Plaza, SW } \\
\text { Suite } 6000 \\
\text { Washington, DC 20024-2168 }\end{array}$ & $\begin{array}{l}\text { pjr@anl.gov } \\
\text { Phone: 202-488-2407 } \\
\text { FAX: 202-488-2413 }\end{array}$ \\
\hline Roland, Scott & $\begin{array}{l}\text { SBCCOM, Battelle Memorial } \\
\text { Institute }\end{array}$ & $\begin{array}{l}\text { ATTN: AMSSB-RCB-RH } \\
\text { APG, MD 21010-5423 }\end{array}$ & $\begin{array}{l}\text { srrowland@sbccom .apgea.army.mil } \\
\text { Phone: 410-436-2342 } \\
\text { FAX: 410-436-2351 }\end{array}$ \\
\hline $\begin{array}{l}\text { Roman, Richard S. } \\
\text { Emergency Response } \\
\text { Coordinator }\end{array}$ & $\begin{array}{l}\text { Bioterriorism Preparedness, } \\
\text { NCID }\end{array}$ & $\begin{array}{l}1600 \text { Clifton Road, NE, M/S E-51 } \\
\text { Atlanta, GA } 30333\end{array}$ & $\begin{array}{l}\text { rsr1@cdc.gov } \\
\text { Phone: 404-639-0393 } \\
\text { FAX: 404-639-0382 }\end{array}$ \\
\hline $\begin{array}{l}\text { Rowley, Linda S., CSP } \\
\text { Occupational Safety \& } \\
\text { Health Mgr. }\end{array}$ & $\begin{array}{l}\text { US Army } \\
\text { Material Command }\end{array}$ & $\begin{array}{l}\text { ATTN: AMCSF-S } \\
\text { 5001 Eisenhower Ave. } \\
\text { Alexandria, VA 22333-0001 }\end{array}$ & $\begin{array}{l}\text { linda_rowley@hqamc.army.mil } \\
\text { Phone: 703-617-9475 } \\
\text { FAX: 703-617-9469 }\end{array}$ \\
\hline $\begin{array}{l}\text { Runge, Dr. Michael L. } \\
\text { Technical Director }\end{array}$ & $\begin{array}{l}\text { 3M Occupational Health and } \\
\text { Environmental Safety Division }\end{array}$ & $\begin{array}{l}\text { 3M Center } \\
\text { 260-2A-03 } \\
\text { St. Paul, MN 55144-1000 }\end{array}$ & $\begin{array}{l}\text { mlrunge@mmm.com } \\
\text { Phone: 651-737-3069 } \\
\text { FAX: 651-733-6655 }\end{array}$ \\
\hline $\begin{array}{l}\text { Sapko, Mike } \\
\text { Physical Scientist }\end{array}$ & $\begin{array}{l}\text { NIOSH } \\
\text { Pittsburgh Research } \\
\text { Laboratory }\end{array}$ & $\begin{array}{l}626 \text { Cochrans Mill Road } \\
\text { Pittsburgh, PA } 15236\end{array}$ & $\begin{array}{l}\text { zia5@cdc.gov } \\
\text { Phone: 412-892-6619 } \\
\text { FAX: 412-892-6718 }\end{array}$ \\
\hline
\end{tabular}




\begin{tabular}{|c|c|c|c|}
\hline Name/Title & Company / Agency & Address & Email/Telephone / FAX \\
\hline $\begin{array}{l}\text { Sawicki, Jack C. } \\
\text { Director, Business } \\
\text { Development }\end{array}$ & $\begin{array}{l}\text { GEOMET Technologies, Inc. } \\
\text { GEOMET Div. }\end{array}$ & $\begin{array}{l}20251 \text { Century Boulevard } \\
\text { Germantown, MD } 20874\end{array}$ & $\begin{array}{l}\text { Sawicjac@Versar.com } \\
\text { Phone: 301-428-9898 } \\
\text { FAX: 301-428-9482 }\end{array}$ \\
\hline $\begin{array}{l}\text { Schneider, Frank* } \\
\text { Vice President of Sales }\end{array}$ & Micronel Safety & $\begin{array}{l}5703 \text { Industry Lane } \\
\text { Frederick, MD } 21704\end{array}$ & $\begin{array}{l}\text { fschneider@micronelsafety.com } \\
\text { Phone: 301-624-5600 } \\
\text { FAX: 301-624-5688 }\end{array}$ \\
\hline $\begin{array}{l}\text { Schorer, Bruce A. } \\
\text { Industrial Marketing } \\
\text { Manager }\end{array}$ & SCOTT Aviation & $\begin{array}{l}309 \text { West Crowell Street } \\
\text { Monroe, NC } 28112\end{array}$ & $\begin{array}{l}\text { bschorer@scottaviation.com } \\
\text { Phone: 704-282-8487 } \\
\text { FAX: 704-282-8424 }\end{array}$ \\
\hline $\begin{array}{l}\text { Scott, Steve, M.D. } \\
\text { Emergency Coordinator }\end{array}$ & US Public Health Service & $\begin{array}{l}3301 \text { S. Day } \\
\text { Seattle, WA } 98144\end{array}$ & $\begin{array}{l}\text { sscot@hrsa.gov } \\
\text { Phone: 206-615-2469 } \\
\text { FAX: 206-615-2481 }\end{array}$ \\
\hline Sell, Bob & Draeger Safety & $\begin{array}{l}101 \text { Technology Drive } \\
\text { Pittsburgh, PA } 15275\end{array}$ & $\begin{array}{l}\text { Bob.Sell@draeger.com } \\
\text { Phone: 412-787-8383 } \\
\text { FAX: 412-787-2207 }\end{array}$ \\
\hline $\begin{array}{l}\text { Shearer, Sam } \\
\text { President }\end{array}$ & CSE Corporation & $\begin{array}{l}600 \text { Seco Road } \\
\text { Monroeville, PA } 15146\end{array}$ & $\begin{array}{l}\text { sbs@csecorporation.com } \\
\text { Phone: 412-856-9200 } \\
\text { FAX: 412-856-9203 }\end{array}$ \\
\hline $\begin{array}{l}\text { Skelly, Larry* } \\
\text { Special Assistant }\end{array}$ & HQDA & $\begin{array}{l}\text { ATTN: SAIE-ESOH (Rm. 2D566) } \\
110 \text { Army Pentagon } \\
\text { Washington, DC 20310-0110 }\end{array}$ & $\begin{array}{l}\text { lawrence.skelly@hqda.army.mil } \\
\text { Phone: 703-614-9047 } \\
\text { FAX: 703-614-4571 }\end{array}$ \\
\hline Smith, Dr. Simon & 3M Canada & $\begin{array}{l}1360 \text { California Avenue } \\
\text { Brockville, Ontario } \\
\text { CANADA K6V5V8 }\end{array}$ & $\begin{array}{l}\text { sjsmith@mmm.com } \\
\text { Phone: 613-345-0111 ext } 3003 \\
\text { FAX: }\end{array}$ \\
\hline $\begin{array}{l}\text { Smith, William } \\
\text { Director of Marketing }\end{array}$ & SCOTT Aviation & $\begin{array}{l}309 \text { W. Crowell } \\
\text { Monroe, NC } 28112\end{array}$ & $\begin{array}{l}\text { wsmith@scottaviation.com } \\
\text { Phone: 704-282-8402 } \\
\text { FAX: 704-282-8424 }\end{array}$ \\
\hline $\begin{array}{l}\text { Steelnack, John } \\
\text { Project Officer }\end{array}$ & OSHA & $\begin{array}{l}\text { Room N37-18 } \\
200 \text { Constitution Avenue, N.W. } \\
\text { Washington, DC } 20210\end{array}$ & $\begin{array}{l}\text { JOHN.STEELNACK@osha-no.osha. } \\
\text { gov } \\
\text { Phone: 202-693-2091 } \\
\text { FAX: 202-219-7125 }\end{array}$ \\
\hline
\end{tabular}




\begin{tabular}{|c|c|c|c|}
\hline Name/Title & Company/Agency & Address & Email/Telephone/FAX \\
\hline $\begin{array}{l}\text { Stein, Bob } \\
\text { General Engineer } \\
\text { Respirator Branch }\end{array}$ & NIOSH, DRDS & $\begin{array}{l}1095 \text { Willowdale Road } \\
\text { Morgantown, WV 26505-2888 }\end{array}$ & $\begin{array}{l}\text { rqs3@cdc.gov } \\
\text { Phone: 304-285-6049 } \\
\text { FAX: 304-285-6030 }\end{array}$ \\
\hline $\begin{array}{l}\text { Stein, Richard L., Ph.D. } \\
\text { Manager, New Business } \\
\text { Development }\end{array}$ & Survivair, Inc. & $\begin{array}{l}3001 \text { S. Susan Street } \\
\text { Santa Ana, CA } 92704\end{array}$ & $\begin{array}{l}\text { rstein@survivair.com } \\
\text { Phone: 714-545-0410 } \\
\text { FAX: 714-850-0299 }\end{array}$ \\
\hline $\begin{array}{l}\text { Svalina, John S. } \\
\text { Industrial Hygienist } \\
\text { Office of the Surgeon }\end{array}$ & $\begin{array}{l}\text { US Army } \\
\text { Headquarters US Army } \\
\text { Material } \\
\text { Command }\end{array}$ & $\begin{array}{l}5001 \text { Eisenhower Ave. } \\
\text { Alexandria, VA } 22333\end{array}$ & $\begin{array}{l}\text { jsvalina@hqamc.army.mil } \\
\text { Phone: 703-617-0240 } \\
\text { FAX: 703-617-8558 }\end{array}$ \\
\hline $\begin{array}{l}\text { Tsang, K. Wing, Ph.D. } \\
\text { Microbiologist }\end{array}$ & $\begin{array}{l}\text { US Army Dugway Proving } \\
\text { Ground }\end{array}$ & $\begin{array}{l}\text { West Desert Test Center } \\
\text { Life Sciences Division } \\
\text { Dugway, UT } 84022\end{array}$ & $\begin{array}{l}\text { Ktsang@dugway-emh3.army.mil } \\
\text { Phone: 435-831-3008 } \\
\text { FAX: 435-831-5716 }\end{array}$ \\
\hline $\begin{array}{l}\text { Turpin, Rod* } \\
\text { Senior Environmental } \\
\text { Scientist } \\
\text { Environmental Response } \\
\text { Team }\end{array}$ & $\begin{array}{l}\text { EPA, Office of Solid Waste and } \\
\text { Emergency Response }\end{array}$ & $\begin{array}{l}\text { USEPA Raritan Depot } \\
2890 \text { Woodbridge Ave., M/S101 } \\
\text { Edison, NJ 08837-3679 }\end{array}$ & $\begin{array}{l}\text { turpin.rod@epamail.epa.gov } \\
\text { Phone: 732-321-6741 } \\
\text { FAX: 732-321-6724 }\end{array}$ \\
\hline $\begin{array}{l}\text { Wagner, Gregory R., MD } \\
\text { Director, DRDS }\end{array}$ & NIOSH, DRDS & $\begin{array}{l}1095 \text { Willowdale Road } \\
\text { Morgantown, WV 26505-2888 }\end{array}$ & $\begin{array}{l}\text { grw3@cdc.gov } \\
\text { Phone: 304-285-5749 } \\
\text { FAX: 304-285-5861 }\end{array}$ \\
\hline $\begin{array}{l}\text { Walters, Bradford S.* } \\
\text { Director, Program } \\
\text { Management }\end{array}$ & ILC Dover, Inc. & $\begin{array}{l}\text { P.O. Box } 266 \\
\text { Frederica, DE } 19946\end{array}$ & $\begin{array}{l}\text { walteb@ilcdover.com } \\
\text { Phone: 302-335-3911 } \\
\text { FAX: 302-335-0762 }\end{array}$ \\
\hline $\begin{array}{l}\text { Warner, Kenton } \\
\text { Vice President }\end{array}$ & Interspiro & $\begin{array}{l}500 \text { East Main Street } \\
\text { Branford, CT } 06405\end{array}$ & $\begin{array}{l}\text { ken.warner@interspiro.com } \\
\text { Phone: 800-468-7788 } \\
\text { FAX: 203-483-9309 }\end{array}$ \\
\hline $\begin{array}{l}\text { Waters, Tina } \\
\text { Risk Management } \\
\text { Safety/Surety Office }\end{array}$ & US Army, SBCCOM & $\begin{array}{l}\text { ATTN: AMSSB-RCB-RS } \\
\text { APG MD } 21010\end{array}$ & $\begin{array}{l}\text { tmwater@sbccom.a pgea.army.mil } \\
\text { Phone: 410-436-2489 } \\
\text { FAX: 410-436-4445 }\end{array}$ \\
\hline
\end{tabular}




\begin{tabular}{|c|c|c|c|}
\hline Name/Title & Company/Agency & Address & Email/Telephone/FAX \\
\hline $\begin{array}{l}\text { Weisman, Dulcie, LtCol } \\
\text { Bioenvironmental } \\
\text { Engineering Programs } \\
\text { Manager }\end{array}$ & $\begin{array}{l}\text { USAF } \\
\text { Bolling AFB }\end{array}$ & $\begin{array}{l}\text { ATTN: AFMOA/SGOE } \\
110 \text { Luke Ave., Rm. } 405 \\
\text { Washington, DC } 20332\end{array}$ & $\begin{array}{l}\text { Dulcie.Weisman@usafsg.bolling. } \\
\text { af.mil } \\
\text { Phone: 202-767-4330 } \\
\text { FAX: 202-767-5302 }\end{array}$ \\
\hline $\begin{array}{l}\text { Wendel, Clifford } \\
\text { SBCCOM Risk } \\
\text { Management }\end{array}$ & US Army, SBCCOM Risk & $\begin{array}{l}5183 \text { Blackhawk Road } \\
\text { APG, MD } 21010\end{array}$ & $\begin{array}{l}\text { Phone: 410-436-3982 } \\
\text { FAX: 410-436-8383 }\end{array}$ \\
\hline $\begin{array}{l}\text { White, Eugene M., Ph.D. } \\
\text { Research IH }\end{array}$ & NIOSH, DPSE & $\begin{array}{l}\text { Hamilton Laboratory } \\
5555 \text { Ridge Avenue } \\
\text { Cincinnati, OH } 45213\end{array}$ & $\begin{array}{l}\text { emw5@cdc.gov } \\
\text { Phone: 513-841-4364 } \\
\text { FAX: 513-841-4364 }\end{array}$ \\
\hline $\begin{array}{l}\text { Wiggins, Jim } \\
\text { Engineer }\end{array}$ & $\begin{array}{l}\text { Neoterik Health Technologies, } \\
\text { Inc. }\end{array}$ & $\begin{array}{l}401 \text { S. Main Street } \\
\text { Woodsboro, MD } 21798\end{array}$ & $\begin{array}{l}\text { jimw@neoterik.com } \\
\text { Phone: 301-845-2777 } \\
\text { FAX: 301-845-2213 }\end{array}$ \\
\hline $\begin{array}{l}\text { Williams, Timothy* } \\
\text { Industrial Hygienist, CIH } \\
\text { Chief, Health Surveillance } \\
\text { Office }\end{array}$ & SBCCOM & $\begin{array}{l}\text { ATTN: AMSSB-RCB-RH } \\
\text { Safety Office } \\
\text { APG MD } 21010\end{array}$ & $\begin{array}{l}\text { twwillia@sbcomm.apgea.army.mil } \\
\text { Phone: 410-436-2302 } \\
\text { FAX: 410-436-2351 }\end{array}$ \\
\hline $\begin{array}{l}\text { Wilmes, Donald P. } \\
\text { Senior Regulatory } \\
\text { Specialist }\end{array}$ & $\begin{array}{l}3 \mathrm{M} \\
\text { Occupational Health \& } \\
\text { Environmental Safety Div. }\end{array}$ & $\begin{array}{l}\text { 3M Center } \\
\text { Building 260-3B-09 } \\
\text { St Paul, MN 55144-1000 }\end{array}$ & $\begin{array}{l}\text { dpwilmes@mmm.com } \\
\text { Phone: 651-733-1383 } \\
\text { FAX: 651-736-7344 }\end{array}$ \\
\hline $\begin{array}{l}\text { Yanchek, Rory } \\
\text { Government Sales \& } \\
\text { Marketing Mgr. }\end{array}$ & $\begin{array}{l}3 \mathrm{M} \\
\text { Occupational Health and } \\
\text { Environmental Safety Div. }\end{array}$ & $\begin{array}{l}5301 \text { Buckyestown Pike } \\
\text { Suite } 200 \\
\text { Frederick, MD } 21701\end{array}$ & $\begin{array}{l}\text { ryanchek@mmm.com } \\
\text { Phone: 301-696-1098 } \\
\text { FAX: 301-695-4413 }\end{array}$ \\
\hline $\begin{array}{l}\text { Zdrok, Joseph } Z \text {. } \\
\text { Technical Director } \\
\text { Respiratory Protection }\end{array}$ & Louis M. Gerson Co., Inc. & $\begin{array}{l}15 \text { Sproat Street } \\
\text { Middleboro, MA } 02346\end{array}$ & $\begin{array}{l}\text { Phone: 508-923-3017 } \\
\text { FAX: 508-947-5442 }\end{array}$ \\
\hline
\end{tabular}

* Registered for workshop but was unable to attend 


\section{APPENDIX C}

\section{GLOSSARY Of ABBREVIATIONS \& ACRONYMS}


ACEP .......................................... College of Emergency Physicians

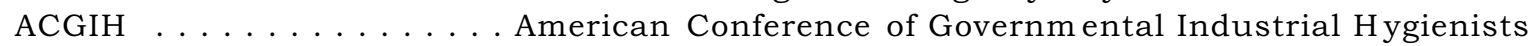

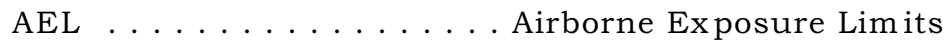

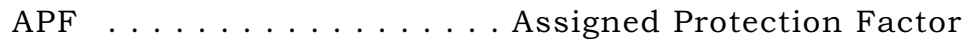

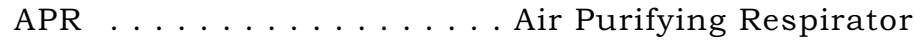

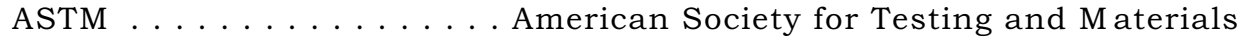

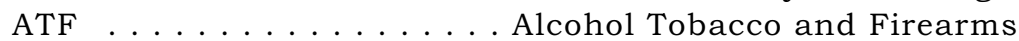

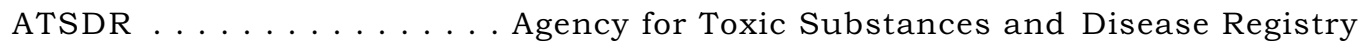

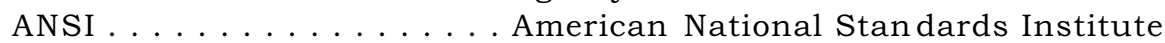

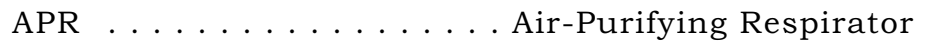

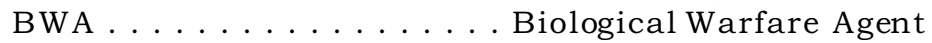

$\mathrm{CB} \ldots \ldots \ldots$ Chemical and/or Biological

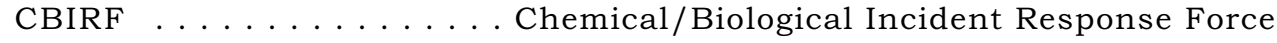

CBRNC . . . . . . . . . . Chemical, Biological, Radiological \& Nuclear Countermeasures

$\mathrm{CDC} \ldots \ldots \ldots . \ldots$ Centers for Disease Control and Prevention

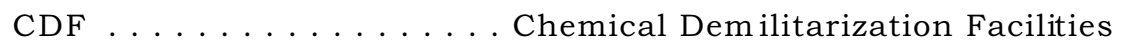

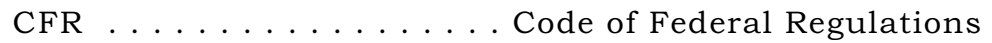

CHPPM ................................. Army Center for Health Promotion \& Preventive Medicine

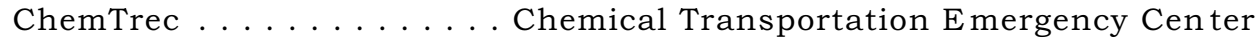

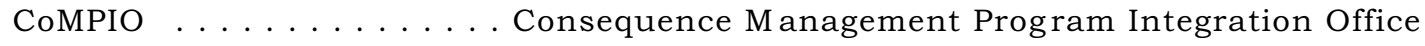

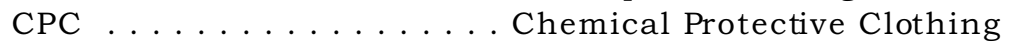

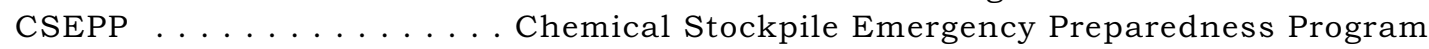

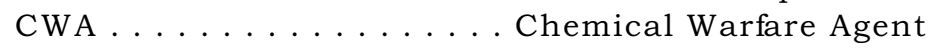

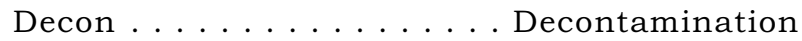

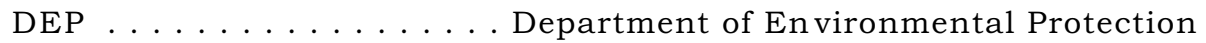

DER ............. Department of Environmental Resources

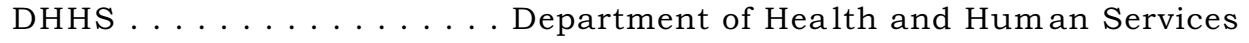

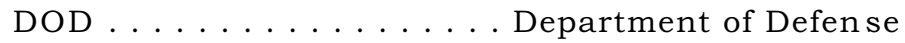

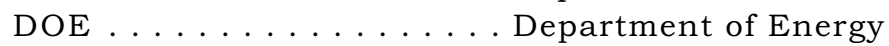

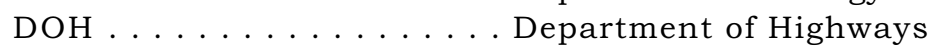

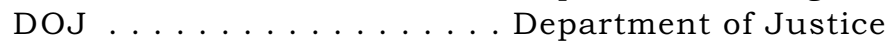

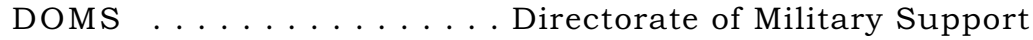

DOT ............. Department of Transportation

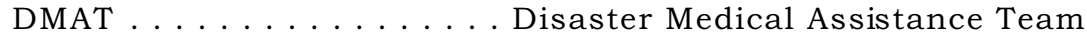

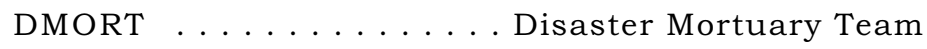

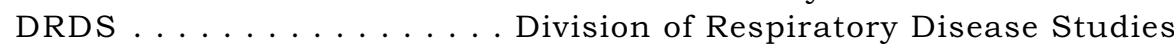

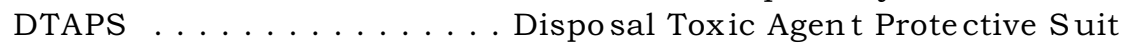

ECBC ......................................... Edgewood Chemical Biological Center

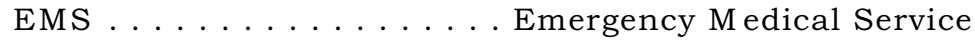

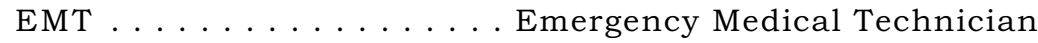

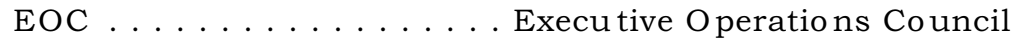

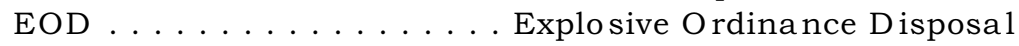

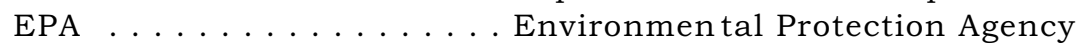

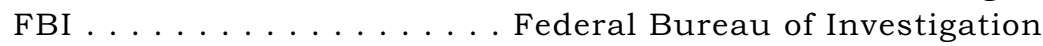

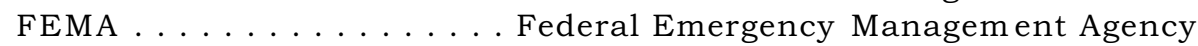

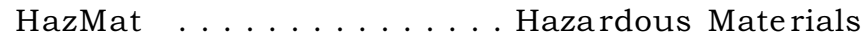

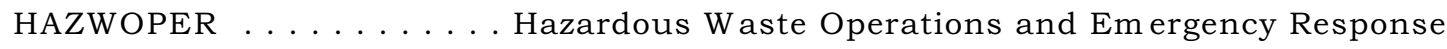

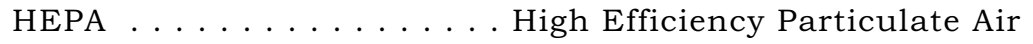

IAFC ............ International Ass ociation of Fire Chiefs 


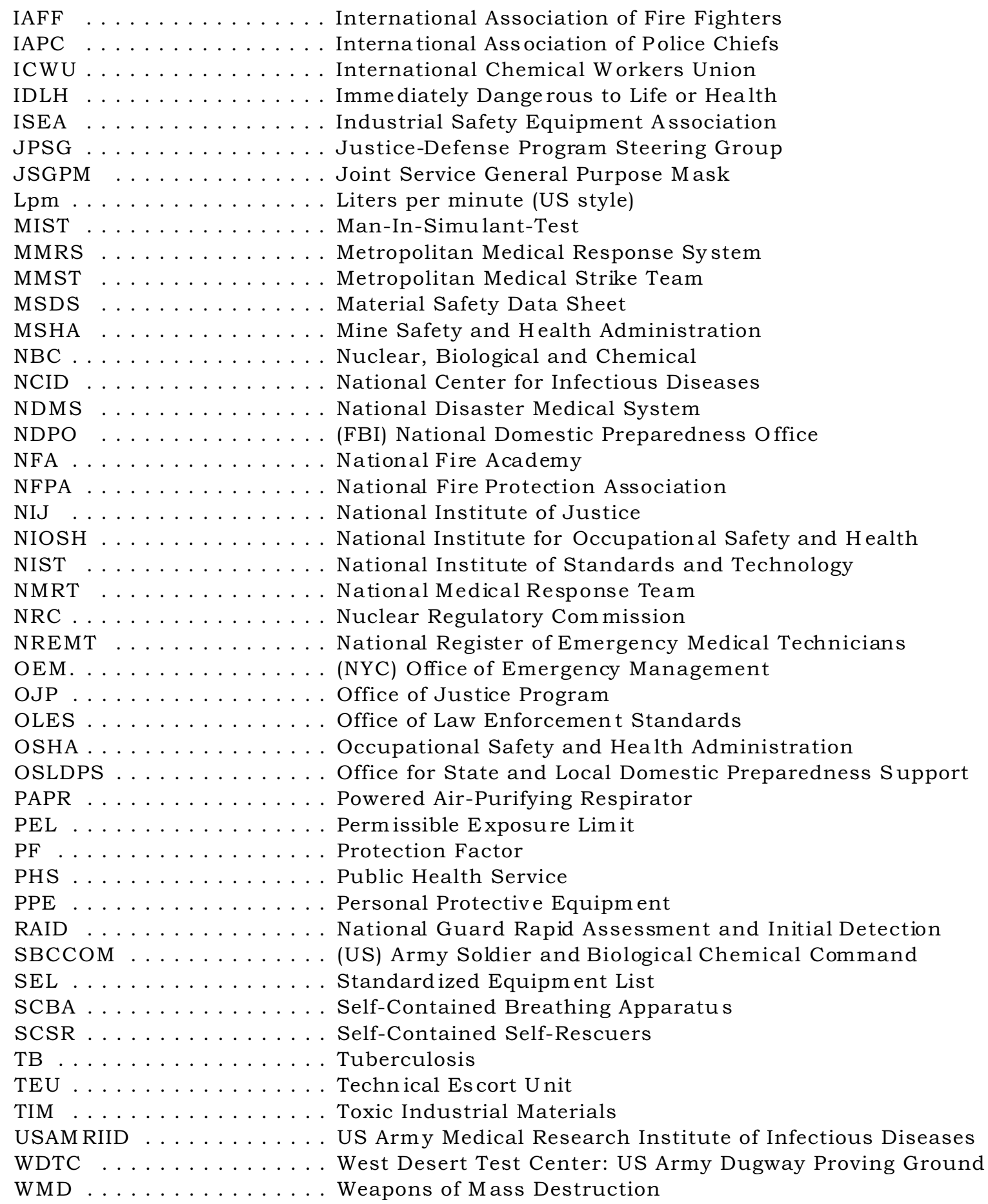




\section{APPENDIX D}

\section{Chemical and Biological Agents of Concern}




\section{Biological Agents}

\begin{tabular}{|c|c|c|}
\hline Disease/Causative Agent & $\begin{array}{l}\text { Incubation } \\
\text { Time }\end{array}$ & Physiological Action \\
\hline Anthrax/B acillus Anthrac is & 1-5 days & $\begin{array}{l}\text { Symptom s include sudden onse t of difficulty } \\
\text { breathing, profuse sweating, cyanosis (blue } \\
\text { colored skin), shock, and death in } 24-36 \text { hou rs if } \\
\text { not treated. }\end{array}$ \\
\hline Plague/Y ersinia Pestis & 1-3 days & $\begin{array}{l}\text { Symptoms include shivering, vomiting, } \\
\text { headaches, giddiness, an intolerance to light, pain } \\
\text { in the back and limbs, and a white coating on } \\
\text { tongue. A fever of } 103-106^{\circ} \mathrm{F} \text { occurs } \\
\text { immediately. Within } 24 \text { hours coughing starts, } \\
\text { then spitting up blood. The plague is an acute } \\
\text { disease, i.e., it normally doesn't last a long time. } \\
\text { If you recover, you will be immune for the rest of } \\
\text { your life. }\end{array}$ \\
\hline Tularemia/Francisella T ularensis & $1-10$ days & $\begin{array}{l}\text { Symptoms resemble flu: fever, chills, headache, } \\
\text { fatigue and muscle aches. Some persons have } \\
\text { pneumonia evident on chest X-rays; some have } \\
\text { chest pain and/or cough and weight loss. Swollen } \\
\text { lymph nod es may also be a symptom. With } \\
\text { antibiotic treatment, Tularemia is only fatal in } 1 \text { - } \\
3 \% \text { of cases. }\end{array}$ \\
\hline Cholera/Vibrio Cholerae & $2-5$ days & $\begin{array}{l}\text { Symptoms include profuse watery diarrhea, } \\
\text { vomiting, and leg cramps. Rapid loss of body } \\
\text { fluids leads to dehydration and shock. Without } \\
\text { treatment, death can occur within hours. }\end{array}$ \\
\hline Venezu elan Equine Encep halitis & $2-5$ days & $\begin{array}{l}\text { Symptom s include sud den onset of illness with } \\
\text { generalized malaise, spiking fevers, rigors, severe } \\
\text { headache, photophobia, and myalgias. Nausea, } \\
\text { vomiting, cough, sore throat, and diarrhea may } \\
\text { follow. Full recovery takes } 1-2 \text { weeks. }\end{array}$ \\
\hline Q Fever/Coxiella B urnetii & $12-21$ days & $\begin{array}{l}\text { Symptoms resemble flu: fever, chills, headache, } \\
\text { fatigue and muscle aches. Approximately } 1 / 2 \text { of } \\
\text { persons with symptoms have pneumonia evident } \\
\text { on chest X-rays; some will have chest pain and/or } \\
\text { cough. The duration of Q Fever is } 2 \text { days to } 2 \\
\text { weeks at which time the disease resolves with no } \\
\text { permane nt effects on the individual. }\end{array}$ \\
\hline
\end{tabular}




\begin{tabular}{|c|c|c|}
\hline Disease/Causative Agent & Latency & Physiological Action \\
\hline $\begin{array}{l}\text { Botulism/Clostridium Botulinum } \\
\text { Toxin }\end{array}$ & 3 days & $\begin{array}{l}\text { Progressive paralysis from the head down. The } \\
\text { individual rem ains mentally alert and awake until } \\
\text { death occurs due to paralysis of the muscles used } \\
\text { for breathing. Botulism is fatal in } 60 \% \text { of the } \\
\text { cases if not treated. }\end{array}$ \\
\hline $\begin{array}{l}\text { Multiple Organ } \\
\text { Toxicity/T richothece ne Myco toxin }\end{array}$ & Dose Dependent & None A vailable \\
\hline $\begin{array}{l}\text { Staphylococcal Enterotoxemia (food } \\
\text { poisoning)/Staphylococcus } \\
\text { Enterotoxin type B }\end{array}$ & $1-6$ days & $\begin{array}{l}\text { Symptoms include sudden onset of high fever } \\
\left(103-106^{\circ} \mathrm{F}\right) \text {, chills, headache, muscle aches, dry } \\
\text { cough, and possible inflamation of the lining of } \\
\text { the eyelids. Altho ugh SEB is not expected to } \\
\text { produc e many fatalities, it has the potential to } \\
\text { incapacitate up to } 80 \% \text { of personnel in the area of } \\
\text { attack. }\end{array}$ \\
\hline
\end{tabular}




\section{Chemical Agents}

\begin{tabular}{|c|c|c|}
\hline \multicolumn{3}{|c|}{ Blister Agents } \\
\hline Chemical Name & Rate of Action & Physiological Action \\
\hline $\begin{array}{l}\text { Distilled Mustard (HD) } \\
\text { Bis(dichloroethyl) sulfide* }\end{array}$ & Delayed - hours to days & $\begin{array}{l}\text { Blisters; destroys tissue; } \\
\text { injures blood cells }\end{array}$ \\
\hline $\begin{array}{l}\text { Nitrogen Mustard (HN-1) } \\
\text { N-ethyl-2,2'-di(chloroethyl)amine* }\end{array}$ & $\begin{array}{l}\text { Delayed - } 12 \text { hours or } \\
\text { longer }\end{array}$ & $\begin{array}{l}\text { Blisters; destroys tissue; } \\
\text { injures blood cells; affects } \\
\text { respiratory tract }\end{array}$ \\
\hline $\begin{array}{l}\text { Nitrogen Mustard (HN-2) } \\
\text { N-methyl-2,2'-di(chloroethyl)amine* }\end{array}$ & $\begin{array}{l}\text { Delayed - } 12 \text { hours or } \\
\text { longer }\end{array}$ & $\begin{array}{l}\text { Blisters; destroys tissue; } \\
\text { injures blood cells; } \\
\text { Bronchopneumo nia possible } \\
\text { after } 24 \mathrm{hrs}\end{array}$ \\
\hline $\begin{array}{l}\text { Nitrogen Mustard (HN-3) } \\
\text { 2,2',2"-Tri(chloroethyl)amine* }\end{array}$ & Delayed - hours to days & $\begin{array}{l}\text { Blisters; destroys tissue; } \\
\text { injures blood cells; affects } \\
\text { respiratory tract }\end{array}$ \\
\hline $\begin{array}{l}\text { Lewisite (L) } \\
\beta \text {-Chlorovinyldichloroarsine* }\end{array}$ & Rapid & $\begin{array}{l}\text { Blisters; destroys tissue; } \\
\text { injures blood cells; systemic } \\
\text { poisoning }\end{array}$ \\
\hline Mustard-Lewisite mixture & $\begin{array}{l}\text { Prompt stinging; } \\
\text { blistering delayed } \\
\text { approximately } 12 \mathrm{hrs}\end{array}$ & $\begin{array}{l}\text { Blisters; destroys tissue; } \\
\text { injures blood cells; systemic } \\
\text { poisoning }\end{array}$ \\
\hline Phenyldichloroarsine (PD) & $\begin{array}{l}\text { Immediate eye effects; } \\
\text { din effects delayed } \\
\text { approximately } 1 \mathrm{hr}\end{array}$ & $\begin{array}{l}\text { Irritates; causes nausea, } \\
\text { vomiting and blisters }\end{array}$ \\
\hline Ethyldichloroarsine (ED) & $\begin{array}{l}\text { Immediate irritation; } \\
\text { delayed blistering }\end{array}$ & $\begin{array}{l}\text { Irritates eyes; blisters; } \\
\text { damages respiratory tract; } \\
\text { systemic poisoning }\end{array}$ \\
\hline Methyldichloroarsine (MD) & $\begin{array}{l}\text { Immediate irritation; } \\
\text { delayed blistering }\end{array}$ & $\begin{array}{l}\text { Irritates Respiratory tract; } \\
\text { injures lungs and eyes; } \\
\text { systemic poisoning }\end{array}$ \\
\hline
\end{tabular}




\begin{tabular}{|l|l|l|}
\hline \multicolumn{2}{|c|}{ Blood Agents } \\
\hline \hline Chemical Na me & Rate of Action & Physiological Action \\
\hline Hydrogen cyanide (AC) & Rapid & $\begin{array}{l}\text { Interferes with body tissues' oxygen } \\
\text { consumption; ac celerates breathing rate }\end{array}$ \\
\hline Cyanogen chloride (CK) & Rapid & $\begin{array}{l}\text { Chokes; irritates; decreases breathing } \\
\text { rate; }\end{array}$ \\
\hline Arsine (SA) & $\begin{array}{l}\text { Delayed action }-2 \mathrm{hr} \text { to } 11 \\
\text { days }\end{array}$ & Damages blood, liver and kidneys \\
\hline
\end{tabular}

\begin{tabular}{|l|l|l|}
\hline \multicolumn{3}{|c|}{ Choking Agents } \\
\hline \hline Chemical Name & Rate of Action & Physiological Action \\
\hline Phosgene (CG) & $\begin{array}{l}\text { Immediate to 3 hr, } \\
\text { depending on } \\
\text { concentration }\end{array}$ & Damages lungs \\
\hline Diphosgene (DP) & $\begin{array}{l}\text { Immediate to 3 hr, } \\
\text { depending on } \\
\text { concentration }\end{array}$ & Damages lungs \\
\hline
\end{tabular}

\begin{tabular}{|l|l|l|}
\hline \multicolumn{3}{|c|}{ Incapacitating Agents } \\
\hline \hline Chemical Name & Rate of Action & Physiological Action \\
\hline 3-Quinuclidinyl benzilate* (BZ) & $\begin{array}{l}\text { Delayed action - 1 to 4 hrs } \\
\text { depending on exposure }\end{array}$ & $\begin{array}{l}\text { Fast heart beat; dizziness; } \\
\text { vomiting; dry mouth; blurred } \\
\text { vision; stupor; random activity }\end{array}$ \\
\hline
\end{tabular}




\begin{tabular}{|l|l|l|}
\hline \multicolumn{2}{|c|}{ Nerve Agents } \\
\hline \hline Chemical Name & Rate of Action & Physiological Action \\
\hline $\begin{array}{l}\text { Tabun (GA) } \\
\text { Dimethylaminoethoxycyanophosphine } \\
\text { oxide* }\end{array}$ & Rapid & Cessation of breath; death \\
\hline $\begin{array}{l}\text { Sarin (GB) } \\
\text { Methylisopropoxyfluorophosphine } \\
\text { oxide* }\end{array}$ & Rapid & Cessation of breath; death \\
\hline $\begin{array}{l}\text { Soman (GD) } \\
\text { Methylpinacolyloxyfluorophosphine } \\
\text { oxide* }\end{array}$ & Rapid & Cessation of breath; death \\
\hline $\begin{array}{l}\text { Cyclohexylsarin (GF) } \\
\text { Cyclohexyl } \\
\text { methylphosphorofluoridate* }\end{array}$ & Rapid & Cessation of breath; death \\
\hline $\begin{array}{l}\text { Methylphosphonothoic acid (VX) } \\
\text { o-ethyl-S-(2-isop ropylaminoethyl) } \\
\text { methylphosphonothiolate* }\end{array}$ & Rapid & $\begin{array}{l}\text { Produces casualties when inhaled or } \\
\text { absorbed }\end{array}$ \\
\hline
\end{tabular}

\section{Tear Agents}

\begin{tabular}{|l|l|l|}
\hline \hline Chemical Name & $\begin{array}{l}\text { Rate of } \\
\text { Action }\end{array}$ & Physiological Action \\
\hline Chloroacetophen one (CN) & Instantaneous & $\begin{array}{l}\text { Causes tearing; irritates eyes and } \\
\text { respiratory tract }\end{array}$ \\
\hline Chloroacetophen one in chloroform (CNC) & Instantaneous & $\begin{array}{l}\text { Causes tearing; irritates eyes and } \\
\text { respiratory tract }\end{array}$ \\
\hline $\begin{array}{l}\text { Chloroacetophen one and chloropicrin in } \\
\text { chloroform (CNS) }\end{array}$ & Instantaneous & $\begin{array}{l}\text { Causes tearing, vomiting, and } \\
\text { choking }\end{array}$ \\
\hline $\begin{array}{l}\text { Chloroacetophenone in benzene and } \\
\text { carbon tetrachloride (CNB) }\end{array}$ & Instantaneous & Causes severe tearing \\
\hline Bromobenzylcyanide (CA) & Instantaneous & Irritates eyes and respiratory tract \\
\hline o-Chlorobenzylmalononitrile (CS) & Instantaneous & $\begin{array}{l}\text { Irritates eyes and } \\
\text { respiratory tract }\end{array}$ \\
\hline Dibenzoxazepine* (CR) & Instantaneous & $\begin{array}{l}\text { Irritates eyes, skin, and respiratory } \\
\text { tract }\end{array}$ \\
\hline Chloropicrin (PS) & Instantaneous & $\begin{array}{l}\text { Causes tearing, vomiting, and } \\
\text { choking }\end{array}$ \\
\hline
\end{tabular}




\begin{tabular}{|l|l|l|}
\hline \multicolumn{2}{|c|}{ Vomiting Agents } \\
\hline \hline Chemical Na me & Rate of Action & Physiological Action \\
\hline Diphenylchloroarsine (DA) & Rapid & $\begin{array}{l}\text { Causes cold symptoms; headache; } \\
\text { nausea, vomiting }\end{array}$ \\
\hline $\begin{array}{l}\text { Adamsite (DM) } \\
\text { Diphenylaminechloroarsine* }\end{array}$ & Rapid & $\begin{array}{l}\text { Causes cold symptoms; headache; } \\
\text { nausea, vomiting }\end{array}$ \\
\hline Diphenylcyan oarsine (DC) & Rapid & $\begin{array}{l}\text { Causes cold symptoms; headache; } \\
\text { nausea, vomiting }\end{array}$ \\
\hline
\end{tabular}

Appendix D information was excerpted from:

1) CBDCOM Domestic Preparedness Program, "Hazards, HAZMAT Technician, EMS Technician Courses," Booz, Allen \& Hamilton Inc., and Science Applications International Corporation, 1998.

2) Bradford, Janet K. "Biological Hazards and Emergency Management." Journal of Contingencies and Crisis Management, Vol. 2/1; 1994, 39-48.

3) Mann, Brad. "Preparing for Infectious Disease Invasions." Emergency Preparedness Digest (Canada), Vol. 22, No. 2; Apr-June 1995, 1618.

* Chemical names added by NIOSH 


\section{APPENDIX E}

\section{Interagency Equipment Standardization Board Members}


Ahmed, Hossan E, PE Anderson, Michael Capt Beaum ont, Steve Lt.

Beban, Edward

Bell, Charles

Bergman, Sh aron

Bogart, Adrian T. Maj

Booth, Joey Maj

Borkow ski, Jeff

Burdick, Brett A.

Cam pagna, Phil

Cochran, John

Crump-Wiesner, Hans

Cullin, David

Daley, Jay LTC

Dower, John M.

Emery, Tom Maj

Eversole, John Chief

Foley, Stephen

Franks, John

Garrett, Ben

Gaudiosi, Rich

Hah n, Eric

Haskell, William

Hodgson, Michae

Holman, Donald MGYSG T

Jacobs, Mark Mr.

Johnson, William

Kinney, Robert

Lechthaler, Brandon

Lee, James

Lukins, Ken

Marcus, Jeffrey

Markey, Raymond

Martinez, Barbara

Murphy, Robert A CWO3

\section{Organization}

DTRA/CBT

USPHS-OEP

Seattle Fire Dept

FDNY HazMat Ops

DoD (CoMPIO)

NIJ

DoD (CoMPIO)

LA State Police

NY Fire Dept-HazMat Ops

VA Dept of Emergency Serv.

US EPA

National Fire Academy

EPA

JPO-BD

MA MSD

NIOSH / DRDS

NGB

Chicago Fire Dept

NFPA

FBI NDPO

TSW G/B attelle

USCG Atlantic Strike Team

Boston Police

USASBC COM Natick

NIOSH / CDC

MARCORSYSCOM

USSOCOM-SOFSA

EWA / LIG

USASBC COM Natick

USCG, HQ

DoD (CoMPIO)

Garner Envir Services

Capt LA City Fire Dept

USASBC COM Natick

FBI WMD

MEF/CBIRF
Telephone

(703)810-4924

(301)443-5709

(206)386-1410

(718)722-3401

(703)693-8983

(703)351-8518

(703)693-8980

(225)925-6113×213

(718)722-3401

(804)897-6569

(732)321-6740

(301)447-1421

(703)603-8821

(703)681-9607

(508)233-6886

(304)285-5907

(703)607-7437

(312)747-6582

(617)984-7465

(202)324-0220

(703)413-8866

(609)724-0008

(617)343-472

(508)233-4477

(202) $401-2414$

(702)784-5898

(606)293-3191

(703)695-2283

(508)233-4425

(202) $267-0427$

(703)693-8981

(210)496-5310

(818)756-8639

(508)233-5433

(202)324-8239

(910)451-5065

\section{E-mail Address}

hossan.ahmed@dtra.mil

manderson@osophs.dhhs.gov

LtBo@aol.com

Hazchief@aol.com

bellc@hqda-aoc.ar my.pentagon.mil

sbergman@sysplan.com

bogarta@hqda-a oc.arm y.pen tagon.mil jbooth@dpsmail.dps.state.la.us

FDNYHMOPS@aol.com

bburdick.des@state.va.us campagna.philip@epa.gov

john.cochran@fema.gov

crump.hans@epamail.epa.gov

cullind@jpobd.osd.mil

daleyj@ma-army.ngb.army.mil

jmd2@cdc.gov

Emeryt@ngb-army.ngb.a rmy.mil

sfoley@NFPA.org

Frank5@rocketmail.com

garrettb@battelle.org

co/ast@m aillant.uscg.mil

erichahn@usa.net

whaskell@natick-amed02.army.mil

muh7@cdc.gov

holmand@quan tico.us mc.mil

markjacobs@sofsa.sair.com

johnsonw@hqda-aoc.army.pen tagon.mil

rkinney@n atick-e mh2 .army.mil

blechthaler@comd t.uscg.mil

leej@hqda-a oc.army.pen tagon.mil

klukins@garner-es.com

1oomup39@aol.com

rmarkey@natick-emh2.army.mil

bymart@erols.com

murphyr@clb.usmc.mil 
O'Conn ell, Jeff

Ryan, Gene Capt.

Shellhammer, Porter T. Chief

Smith, Markham

Stedman, John

Steinmetz, Jay Col

Swan, Chuck P.

Thomas, Wes Chief

Watson, Ronald D. Chief

Whipple, Matthew

White, Andrew
TSW G/Battelle

Chicago Fire Dept

Sarasota County FD, FL

DTRA/CB

NIJ

DoD (CoMPIO)

JPO-BD

Downers Grove Fire Dept

LA County Fire Dept

USASBC COM Natick

IAFC
(703)413-8866

(773)233-4112

(941)951-4211

(703)326-8572

(202)616-0102

(703)693-8977

(703)681-9600

(630)434-5990

(323) $881-2389$

(508)233-4047

(703)273-0911 oconnelj@battelle.org

hitsq@aol.com

pshellha@co.sarasota.fl.us

mark.smith@osia.mil

stedmanj@ojp.usdoj.gov

steinm ej@hqda-aoc.arm y.pen tagon.mil

swanc@jpobd.osd.mil

Wes@mw.sisna.com

ellom8@aol.com

mwhipple@natick-am ed02.army.mil

iems@iafc.org 


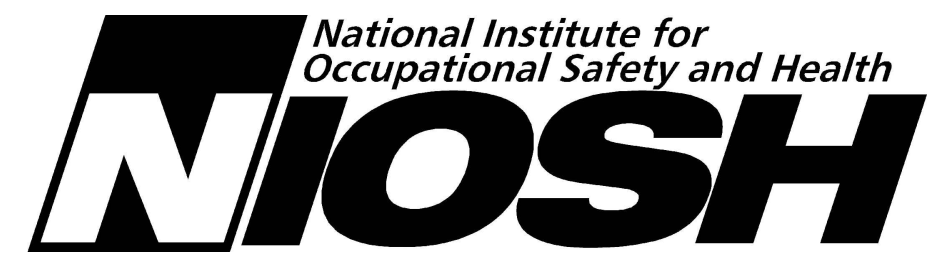

\section{Delivering on the Nation's Promise: \\ Safety and health at work \\ For all people \\ Through research and prevention}

Copies of National Institute for Occupational Safety and Health (NIOSH) documents and information

about occupational safety and health are available from

NIOSH_Publications dissemination

4676 Columbia Parkway

Cincinnati, OH 45226-1998

\begin{tabular}{|c|c|}
\hline ax: & \\
\hline & $\begin{array}{l}1-800-35-\mathrm{NIC} \\
(1-800-356-4\end{array}$ \\
\hline & www.cdc.gov/niosh \\
\hline
\end{tabular}

DHHS (NIOSH) Publication No. 2000-122 